\title{
IMMUNOLOGICAL AND DIABETOLOGICAL FEATURES OF CHRONIC
}

PANCREATITIS

Ph.D. Thesis

Viktória Terzin, M.D.

First Department of Medicine,

University of Szeged

Szeged, Hungary 


\section{CONTENTS}

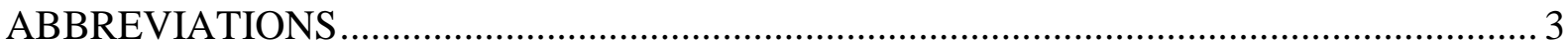

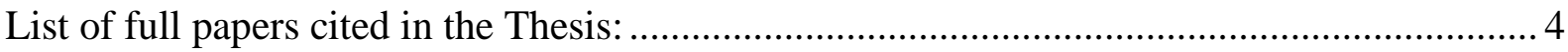

List of full papers related to the subject of the Thesis ....................................................... 4

List of full papers not related to the subject of Thesis ....................................................... 5

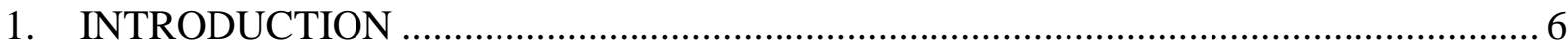

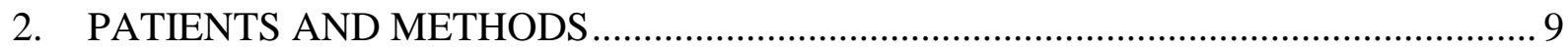

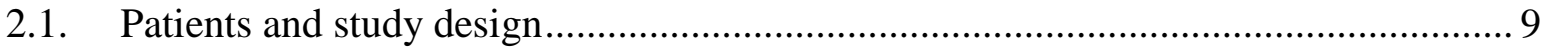

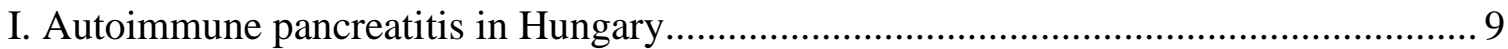

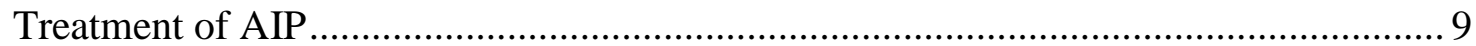

II. Association between autoimmune pancreatitis and systemic autoimmune diseases ... 10

III. Improved glycemic control in pancreatic diabetes through intensive conservative

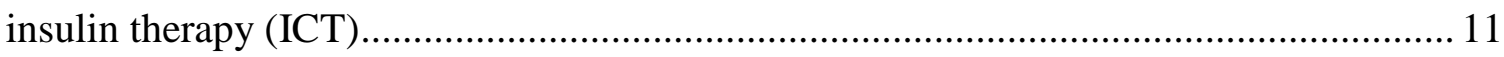

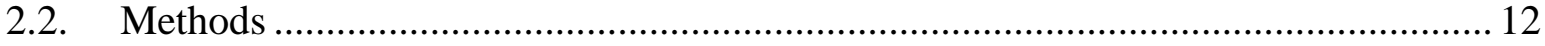

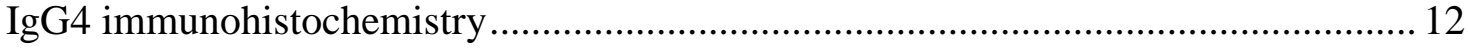

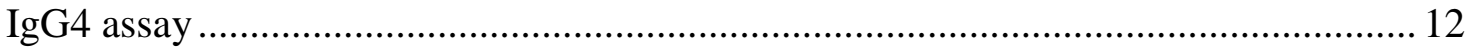

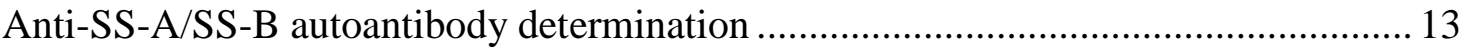

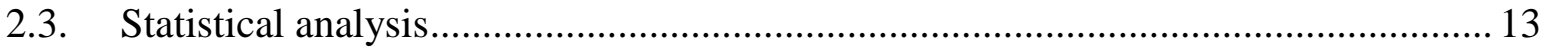

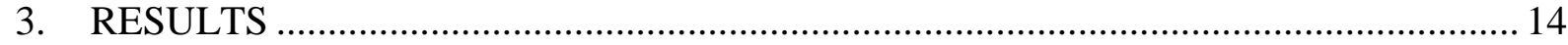

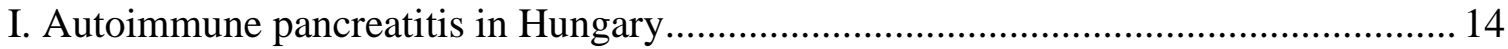

II. Association between autoimmune pancreatitis and systemic autoimmune diseases ... 18

III. Improved glycemic control in pancreatic diabetes through intensive conservative

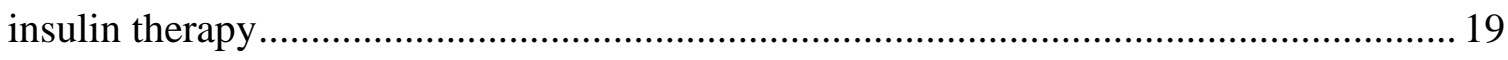

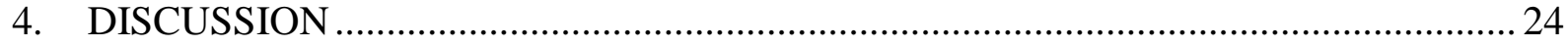

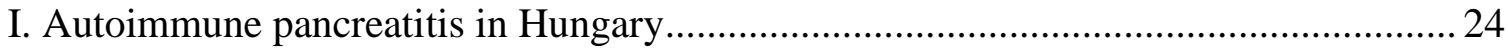

II. Association between autoimmune pancreatitis and systemic autoimmune diseases ... 26

III. Improved glycemic control in pancreatic diabetes through intensive conservative insulin therapy 
5. NEW RESULTS ESTABLISHED IN THE THESIS.

I. Autoimmune pancreatitis in Hungary.....

II. Association between autoimmune pancreatitis and systemic autoimmune diseases ... 31

III. Improved glycemic control in pancreatic diabetes through intensive conservative insulin therapy

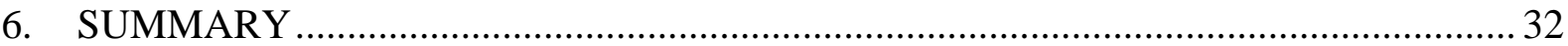

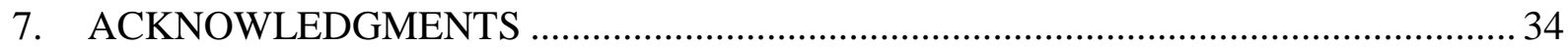

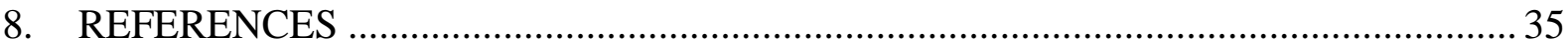

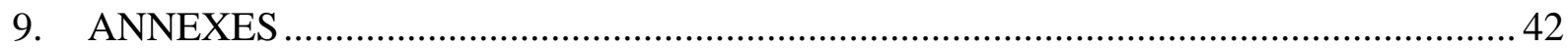




\author{
ABBREVIATIONS \\ AIP - autoimmune pancreatitis \\ $\mathrm{CP}$ - chronic pancreatitis \\ CT - computed tomography \\ DCCT - Diabetes Control and Complications Trial \\ $\mathrm{DM}$ - diabetes mellitus \\ ERCP - endoscopic retrograde cholangiopancreatography \\ GEL - granulocyte epithelial lesion \\ HE - hematoxylin eosin staining \\ ICT - intensive conservative insulin treatment \\ IDCP - idiopathic duct centric chronic pancreatitis \\ IgG - immunoglobulin G \\ LPSP - lymphoplasmacytic sclerosing pancreatitis \\ PMI - pre-mixed insulin \\ SAIDs - systemic autoimmune diseases \\ SLE - systemic lupus erythematosus \\ SS - Sjögren's syndrome \\ UKPDS - UK Prospective Diabetes Study \\ US - ultrasonography
}




\section{List of full papers cited in the Thesis:}

I. Czakó L, Gyökeres T, Topa L, Sahin P, Takács T, Vincze Á, Dubravcsik Zs, Szepes A, Pap Á, Földesi I, Terzin V, Tiszlavicz L, Wittmann T. Autoimmune pancreatitis in Hungary. A Multicenter Nationwide Study. Pancreatology 2011; 11:261-267.

IF: 1.987

II. Terzin V, Földesi I, Kovács L, Pokorny Gy, Wittmann T, Czakó L. Association between autoimmune pancreatitis and systemic autoimmune diseases. World Journal of Gastroenterology 2012; 18: 2649-2653.

IF: 2.471

III. Terzin V, Takács R, Lengyel Cs, Várkonyi T, Wittmann T, Pálinkás A, Czakó L. Improved glycemic control in pancreatic diabetes through intensive conservative insulin therapy. Pancreatology 2012; 12:100-103.

IF: 1.987

IV. Terzin V, Takács R, Lengyel Cs, Várkonyi T, Wittmann T, Pálinkás A, Czakó L. Inzulinkezelés pancreatogen diabetes mellitusban. Diabetologia Hungarica 2012 (in press)

Sum of impact factors (IF) for base references:

\section{List of full papers related to the subject of the Thesis}

I. Terzin V, Várkonyi T, Szabolcs A, Lengyel Cs, Takács T, Palkó A, Wittmann T, Pálinkás A, Czakó L. An exocrine pancreatic dysfunction is associated with poor glycemic control in type 2 diabetes. Hepato-Gastroenterol 2012 (submitted)

II. Szepes Z, Dobra M, Góg Cs, Zábrák E, Makula É, Tiszlavicz L, Kiss T, Molnár T, Nagy F, Czakó L, Terzin V, Wittmann T. Pancreas tumor vagy autoimmun pancreatitis (?), avagy az endoszonográf mint diagnosztikus revizor. Orvosi Hetilap 2012 (accepted) 


\section{List of full papers not related to the subject of Thesis}

I. Czakó L, Terzin V, Szalóki T. Shall we use endoscopic submucosal dissection for every gastric neoplasia? J Gastroenterol 2012; 47:347-348.

II. Czakó L, Dobra M, Terzin V, Tiszlavicz L, Wittmann T. Sepsis and hepatitis together with herpes simplex esophagitis in an immunocompetent adult. Digest Endosc 2012 doi: 10.1111/j.1443-1661.2012.01345.x (in press)

III. Baranyai T, Terzin V, Vajda Á, Wittmann T, Czakó L. Hypertriglyceridemia causes more severe course of acute pancreatitis. Clin Lipidol 2012; 7 (in press)

IV. Baranyai T, Terzin V, Vajda Á, Wittmann T, Czakó L. Hypertrigliceridaemia okozta akut pancreatitis sajátosságai beteganyagunkban. Orvosi Hetilap 2010; 151:18691874. 


\section{INTRODUCTION}

Autoimmune pancreatitis (AIP) is an increasingly recognized special type of chronic pancreatitis (CP), which displays clinical, morphological, serological, radiological and in particular histological features that are clearly distinct from those of other types of CP, such as alcoholic, hereditary and paraduodenal CP. Additionally, glucocorticosteroid responsiveness is one of its more important features. The characteristics of the disease have been described in detail in excellent reviews [1 -5$]$.

Most cases of AIP have been reported from Japan. Although AIP is currently more often recognized in Europe [6 - 10], the number of European clinical reports to date is low and no study is available from central Eastern Europe. AIP predominantly affects males over the age of 50 years. Recent studies demonstrated that two distinct histological patterns of AIP exist [9 - 11]. The histological pattern in type 1 AIP, referred to as lymphoplasmacytic sclerosing pancreatitis (LPSP), is characterized by a periductal lymphoplasmacytic infiltration, storiform fibrosis, obliterative phlebitis and IgG4-positive plasma cells. LPSP corresponds to the Japanese description of AIP [12] and is thought to be the pancreatic manifestation of an IgG4-associated systemic disease [13]. The histopathological pattern in type 2 AIP is known as idiopathic duct centric CP (IDCP) or granulocyte epithelial lesion (GEL)-positive pancreatitis, which resembles the European description of duct-destructive CP [9, 14].

Immunological examinations in AIP patients have demonstrated high incidences of hypergammaglobulinemia (43\%), increased serum levels of immunoglobulin-G (IgG) (62$80 \%)$ and IgG4 (68-92\%), and the presence of antinuclear antibodies (40-64\%) and rheumatoid factor $(25 \%)$. Among all the serological diagnostic features, an elevated serum level of IgG4 has the highest individual diagnostic value; however, it is not disease-specific. Furthermore, an elevated serum IgG4 level correlates with the activity of AIP $[15,16]$. Kamisawa et al. reported an association between the serum IgG4 level and extrapancreatic lesions in patients with AIP. AIP patients with a serum IgG4 level of $\geq 2200 \mathrm{mg} / \mathrm{L}$ frequently exhibit extrapancreatic lesions [17].

The immunological and histological features of AIP and the glucocorticosteroid responsiveness suggest an autoimmune mechanism for the development of the disease [18]. AIP is accompanied by some other autoimmune disease (sclerosing cholangitis, sclerosing 
sialadenitis, retroperitoneal fibrosis, enlarged celiac and hilar lymph nodes, chronic thyroiditis, interstitial nephritis, etc.) in 50-63\% of the cases, suggesting that AIP may be a systemic disorder [1, $3-5]$. The occurrence of autoimmune diseases in association with AIP is well documented $[13,19]$, but the incidence of such associations has not been reported.

$\mathrm{CP}$ can cause different serious complications. One of them is pancreatic diabetes mellitus (DM), which develops from the impairment of the pancreatic endocrine function due to the progression of a pancreatic disease such as acute or chronic pancreatitis, pancreatic surgery or pancreatic carcinoma [20 - 22]. The World Health Organization has distinguished pancreatic DM from types 1 and 2 DM and classified it as a specific subtype (type 3c) [23].

The reported prevalence of DM in CP varies between 30 and 83\% [21, 22, 24, 25]. Overall, exocrine pancreatic diseases are believed to be responsible for DM in around $8 \%$ of the cases, but in as many as 15-20\% of DM patients in South-East Asia, where tropical pancreatitis is endemic [26]. However, the prevalence of CP may be much higher than previously estimated in the general population, and DM secondary to $\mathrm{CP}$ could be more common, which would explain the frequent finding of an exocrine pancreatic insufficiency in diabetics [27, 28].

Insulin $(\beta)$, glucagon $(\alpha)$, pancreatic polypeptide and somatostatin $(\delta)$ - producing cells are destroyed in pancreatic DM [29 - 32]. The pathomechanism and clinical features of pancreatic DM therefore differ from those of types 1 and $2 \mathrm{DM}$, and the principles of its treatment may also differ [24]. However, there appears to be a lack of consensus regarding the management of patients with pancreatic DM [33], as they do not fit into either the type 1 or 2 DM guidelines recommended by professional bodies [34, 35]. All the large clinical trials, including the UK Prospective Diabetes Study (UKPDS) and the Diabetes Control and Complications Trial (DCCT), specifically excluded patients with pancreatic DM; accordingly, data are lacking as concerns modern evidence-based practice in this group of patients.

The first and most important defensive mechanism against hypoglycemia is glucagon secretion. The risk of hypoglycemia in pancreatic DM is increased because of the absence of glucagons, alcohol consumption, inadequate nutrition and impaired nutrient absorption due to an exocrine pancreatic insufficiency.

Our aims were

1) to assess the clinical features, laboratory and imaging findings, extrapancreatic involvement, treatment response and recurrence of AIP cases in Hungary; 
2) to assess the presence of AIP in different systemic autoimmune diseases (SAIDs) through measurement of the serum IgG4 level and examination of the morphology of the pancreas; and

3) to evaluate the effectivity of insulin therapy from the aspects of glycemic control, body weight and safety in patients with DM secondary to underlying $\mathrm{CP}$ with initially inappropriate glycemic control. 


\section{PATIENTS AND METHODS}

\subsection{Patients and study design}

\section{Autoimmune pancreatitis in Hungary}

Between May 1, 2008, and October 30, 2010, patients diagnosed with AIP in Hungarian gastroenterological centers were enrolled in our study. Patient data were retrieved from the medical documentation and follow-up data were collected prospectively. All the patients participated in the continuous clinical follow-up.

Treatment was carried out in the course of everyday clinical practice. All the patients underwent abdominal computed tomography (CT). If obstructive jaundice occurred in AIP, therapeutic endoscopic retrograde cholangiopancreatography (ERCP) was performed, and a polyethylene stent was inserted into the bile duct if optimization of the bile flow was necessary. Depending on the local possibilities, magnetic resonance cholangiopancreatography and/or diagnostic ERCP were performed to visualize abnormalities in the biliopancreatic region. When focal enlargement of the pancreas was detected, ultrasound-guided fine-needle aspiration or core biopsy was carried out. If the papilla of Vater was swollen, the biopsy was taken by means of duodenoscopy.

The diagnosis of type 1 AIP was established according to the HISORt criteria [36]; it was supported by the presence of duct centric lymphoplasmacytic infiltration, storiform fibrosis, obliterative phlebitis and >10 IgG4-positive plasma cells per high power field. Type 2 AIP was distinguished on the basis of the presence of the histological criterion GEL [9, 11]; IgG4 seronegativity refers to type 2 AIP, too.

\section{Treatment of AIP}

After the diagnosis of AIP had been established, the patients were treated with 30-40 mg prednisolone per day for 1-2 months. After 4 weeks, the response was assessed. The response to therapy was defined as complete when a symptomatic improvement and complete resolution of the imaging abnormalities were seen. In the event of an adequate therapeutic response, the steroid dose was tapered to $5 \mathrm{mg} /$ week. If a relapse occurred during the decrease 
in the steroid dose, the level of prednisolone was increased during the acute flare-up, and azathioprine at a dose of $1-2 \mathrm{mg} / \mathrm{kg}$ body weight per day was added for long-term immunosuppression. In patients who had undergone stent implantation in the bile duct, ERCP examination was repeated after steroid therapy; in the event of improvement of the stenosis, the stent was removed.

\section{Association between autoimmune pancreatitis and systemic autoimmune diseases}

Serum samples were obtained from 61 patients with various SAIDs who had been admitted to our Department of Rheumatology and had not participated in glucocorticosteroid treatment during the past 2 years. 1 male and 60 females (mean age 54.5 y, range 29-82 y) were recruited. The most frequent diagnosis was Sjögren's syndrome (SS), but systemic lupus erythematosus (SLE), Hashimoto's thyroiditis, Raynaud's syndrome, polymyositis and systemic sclerosis also occurred (Table 1.). Serum samples were additionally obtained from 7 age- and sex-matched healthy subjects, and 6 patients with AIP. In 1 AIP patient, the AIP was accompanied by rheumatoid arthritis and ankylosing spondylitis.

TABLE 1. DISTRIBUTION OF GENDER AND AGE IN PATIENTS WITH DIFFERENT SYSTEMIC AUTOIMMUNE DISEASES, AUTOIMMUNE PANCREATITIS AND IN CONTROL GROUP

\begin{tabular}{lccc}
\hline & No. of patients & Male/ Female & $\begin{array}{c}\text { Mean age } \\
\text { [y (range) }\end{array}$ \\
\hline SS & 35 & $1 / 34$ & $56.7(29-82)$ \\
SLE & 22 & $0 / 22$ & $50.2(31-68)$ \\
Systemic sclerosis & 4 & $0 / 4$ & $59.5(45-80)$ \\
Normal subjects & 7 & $4 / 3$ & $68(56-80)$ \\
AIP & 6 & $3 / 3$ & $53.7(27-75)$ \\
\hline
\end{tabular}


Patients with a serum IgG4 level of $>400 \mathrm{mg} / \mathrm{L}$ were examined by a gastroenterologist. The clinical and laboratory data were reviewed and abdominal ultrasonography (US) and CT were performed.

Autoimmune diseases were diagnosed according to standard diagnostic criteria [37 40].

\section{Improved glycemic control in pancreatic diabetes through intensive conservative insulin therapy (ICT)}

Pancreatic DM patients with $\mathrm{HbA1c}>7.0 \%$ were recruited into the third study between January 1, 2007 and December 31, 2010. Depending on the antidiabetic therapy administered up to the time of recruitment, the patients were divided into three groups. In Groups A and B, the baseline antidiabetic therapy was oral medication, while in Group C it was pre-mixed insulin (PMI) (Table 2.). Patients with cystic fibrosis were excluded from the study.

TABLE 2. CLINICAL CHARACTERISTICS OF PANCREATIC DIABETIC PATIENTS

\begin{tabular}{lccc}
\hline & Group A & Group B & Group C \\
\hline No. of Patients (cases) & 16 & 8 & 10 \\
Male/female & $14 / 2$ & $5 / 3$ & $7 / 3$ \\
Mean age (range) (y) & $54.1(36-76)$ & $60.6(46-76)$ & $58.6(37-76)$ \\
Mean weight (range) $(\mathrm{kg})$ & $72.1(60-103.3)$ & $72.7(40.5-94)$ & $77.4(59-104)$ \\
Mean duration of CP (y) & $9.4 \pm 6.2$ & $15.9 \pm 6.5$ & $16.9 \pm 8.8$ \\
Pancreatic surgery (cases) & $7 / 16$ & $3 / 8$ & $6 / 10$ \\
Calcification (cases) & $13 / 16$ & $4 / 8$ & $4 / 10$ \\
Alcoholic etiology & $12 / 16$ & $4 / 8$ & $5 / 10$ \\
Mean duration of diabetes (y) & $9.2 \pm 4.0$ & $14.5 \pm 5.4$ & $16.5 \pm 8.3$ \\
Mean HbA1c (\%) & $9.7 \pm 1.8$ & $10.0 \pm 1.4$ & $8.8 \pm 1.7$ \\
\hline
\end{tabular}

Because of the inappropriate glycemic control, the initial oral medication was switched to ICT (short-acting insulin three times per day before meals and an intermediateacting insulin injection before sleep) in Group A and to twice daily PMI in Group B. Poor compliance or the loss of sight was the reason for the change to PMI instead of ICT in Group B. The initial PMI therapy was switched to ICT in Group C (Fig. 1). The changes in HbA1c, 
fasting plasma glucose, body weight and hypoglycemic events were followed from baseline to 2 years. All the patients were on pancreatic enzyme replacement therapy with $3-5 \times 25.000$ $-75.000 \mathrm{IU}$ doses of pancreatin.

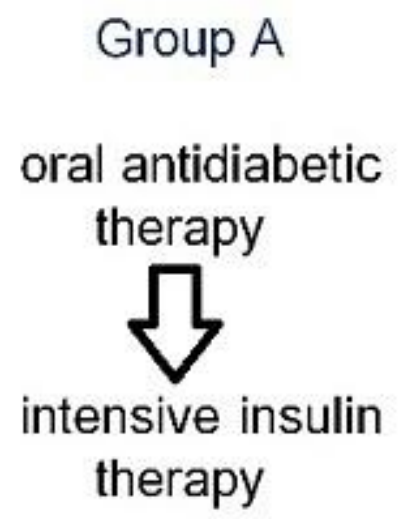

Group B

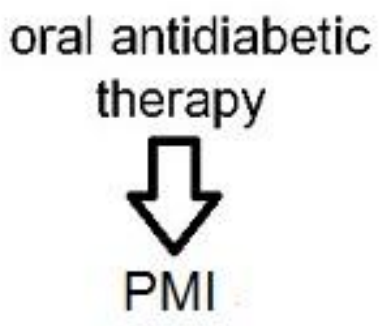

Group C

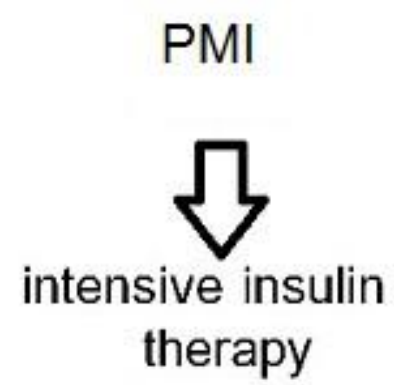

Fig. 1. Depending on the antidiabetic therapy administered up to the time of recruitment, the patients were divided into three groups.

The diagnosis of DM was established in accordance with the criteria of the American Diabetes Association [23]. CP was diagnosed on the basIs of morphological and functional diagnostic criteria [41].

\subsection{Methods}

IgG4 immunohistochemistry

IgG4 immunohistochemical staining of cells or tissue samples was performed with monoclonal anti-human IgG4 antibody (Invitrogen, Carlsbad, CA, USA).

\section{IgG4 assay}

After collection, serum samples were stored at $-70{ }^{\circ} \mathrm{C}$ until analyzed. The $\operatorname{IgG} 4$ subclass was determined by the radial immunodiffusion (RID) method (The Binding Site Limited, Birmingham, UK). The diameters of precipitation rings were measured after $72 \mathrm{~h}$. The results were read off by using the RID reference table. The lowest detection limit was 
$22.4 \mathrm{mg} / \mathrm{L}$. The intra- and interassay coefficients of variation were 3.26 and $0.89 \mathrm{CV} \%$, respectively, as stated by the manufacturer. A cutoff value of $400 \mathrm{mg} / \mathrm{L}$ was employed.

\section{Anti-SS-A/SS-B autoantibody determination}

The presence of anti-SS-A/SS-B autoantibodies was determined by means of enzymelinked immunosorbent assay (ELISA) through the use of commercial kits, conducted according to the protocols provided by the manufacturers.

\subsection{Statistical analysis}

Experimental data were evaluated statistically using the $\chi^{2}$ test, the independentsamples $t$ test and the paired samples $t$ test. Values of $p<0.05$ were accepted as statistically significant. Statistical data are expressed as means $\pm \mathrm{SD}$. 


\section{RESULTS}

\section{Autoimmune pancreatitis in Hungary}

In the first study, AIP was diagnosed in 17 patients during the study period. At the time of establishment of the diagnosis, the median age of the patients was 42.7 years (range: 16-74); $47 \%$ of them were women (Table 3.). The most frequent symptoms were mild abdominal pain, a moderate weight loss and obstructive jaundice. In 5 patients (29\%), inflammatory bowel disease had been diagnosed earlier, 2 patients had type $1 \mathrm{DM}$ and another patient had sialadenitis. The serum levels of pancreatic enzymes and Ca 19-9 were mildly elevated in $40 \%$ of the 15 and $17 \%$ of the 6 patients, respectively, in whom it was evaluated. The serum IgG4 level at presentation was elevated in $62 \%$ of the 8 patients in whom it was assessed. Serum levels of antinuclear antibody were increased in $50 \%$ of the patients in whom it was measured.

TABLE 3. CLINICAL PRESENTATION OF THE PATIENTS WITH AUTOIMMUNE PANCREATITIS

\begin{tabular}{lc}
\hline \hline Mean age (range) (y) & $42.7(16-74)$ \\
No. of females (cases) & $8(47 \%)$ \\
Abdominal pain (cases) & $13(76 \%)$ \\
Weight loss (cases) & $7(41 \%)$ \\
Obstructive jaundice (cases) & $7(41 \%)$ \\
DM (cases) & $2(12 \%)$ \\
Autoimmune disorder (cases) & $8(47 \%)$ \\
\hline \hline
\end{tabular}

Imaging examinations revealed a diffuse, sausage-like widening of the pancreas in 7 patients $(41 \%)$ and focal enlargement of the pancreas in 8 patients $(47 \%$; Fig. 2a,c), while in 2 patients $(12 \%)$ the pancreas did not exhibit any enlargement. In $66 \%$ of the patients with type 2 AIP, there was a focal mass in the pancreas. ERCP revealed stenosis of Wirsung's duct with a wall irregularity in all of the study patients; in 4 patients $(33 \%)$, the stenosis was diffuse, and in 8 patients $(67 \%)$ it was segmental (Fig. 3a,b). Seven patients (41\%) had obstructive jaundice; ERCP revealed stenosis of the intrapancreatic portion of the common 
bile duct (Fig. 3b) in all of them; a stent was implanted in 3 patients to ensure the bile flow.

These stents were removed after resolution of the strictures following steroid therapy.

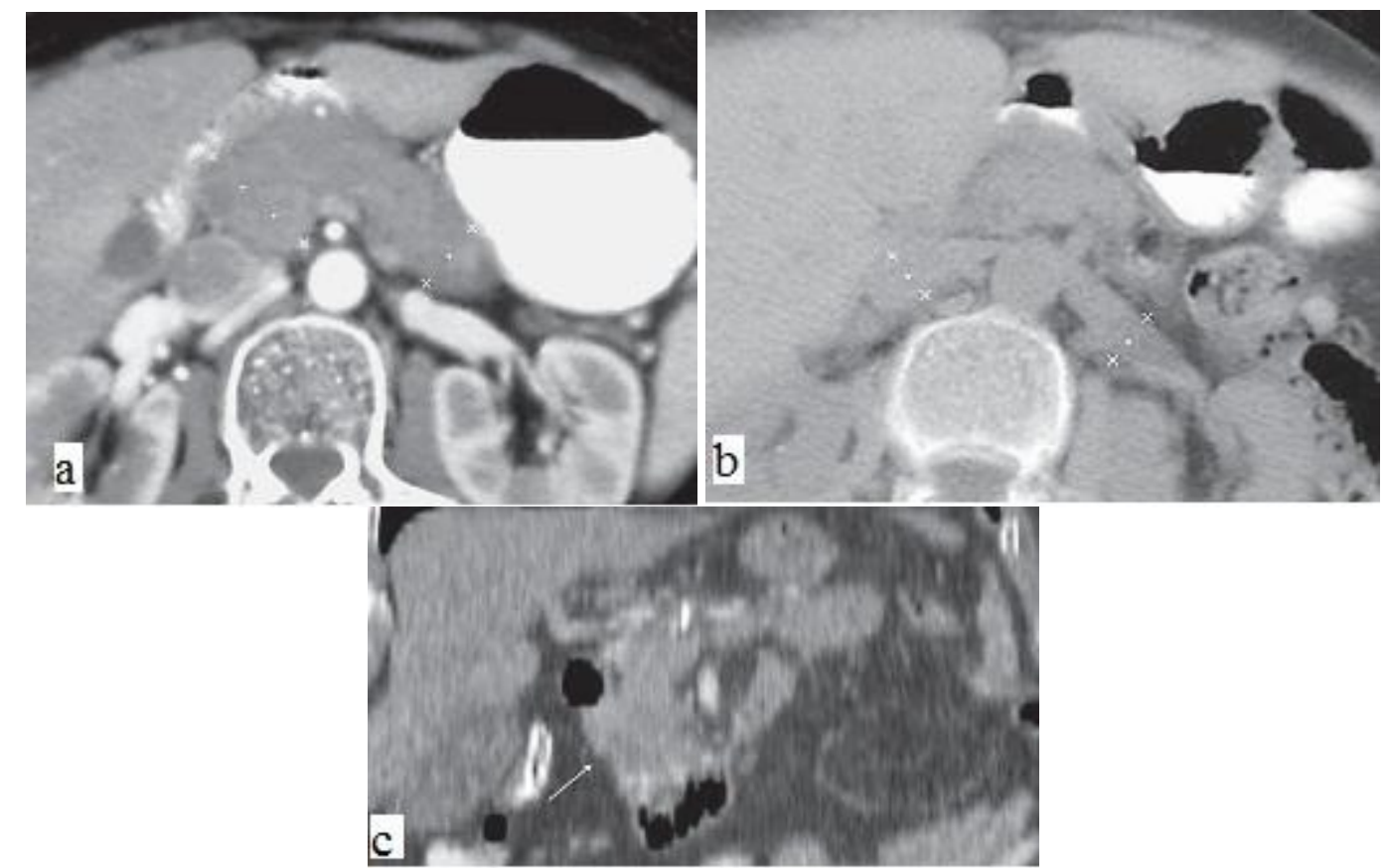

Fig. 2. CT scan demonstrating diffuse enlargement of the pancreas in a 62-year-old female patient (a). Following 4-week steroid treatment (32 mg), she is symptom-free, and the pancreas volume has become normal (b). CT reveals focal enlargement (arrow) of the pancreas in a 72-year-old male (c).
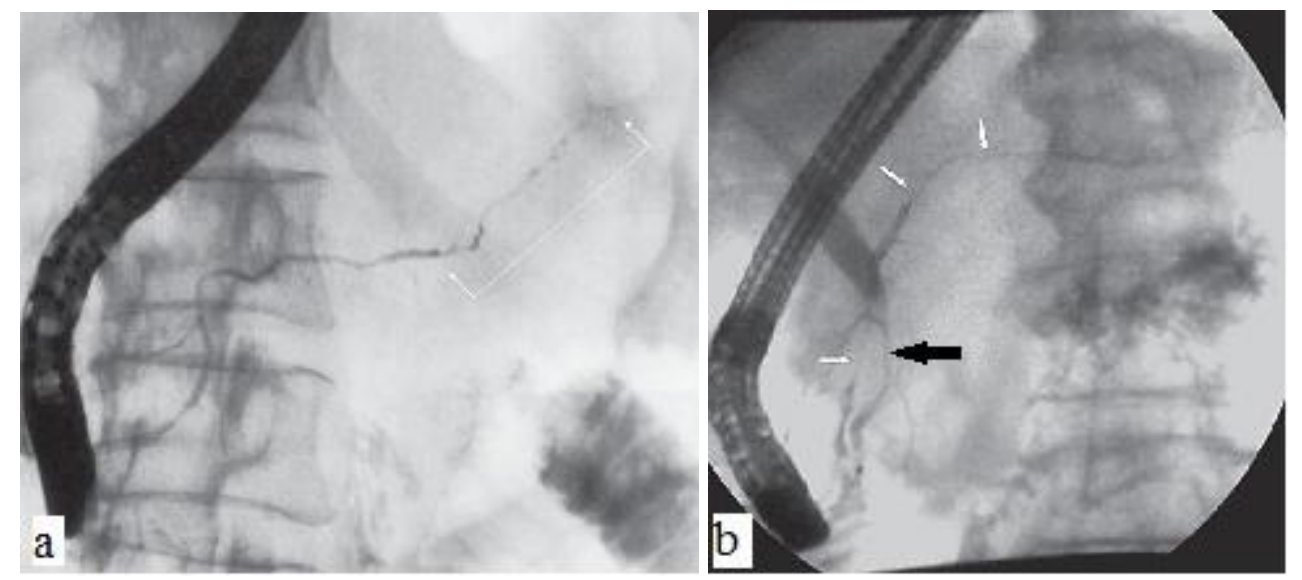

Fig. 3. ERCP reveals diffuse irregular stenosis of the pancreatic duct (a) and multiple segmental stenosis of the pancreatic duct without upstream dilation (arrows), and a stricture of the intrapancreatic portion of the common bile duct (black arrow; b). 
For histological examination, sampling was performed by different means. In 1 case the sample obtained by ultrasound-guided fine-needle aspiration was not appropriate for establishment of the diagnosis of AIP; however, cytological examination did not reveal tumor cells either. All 5 cases who provided a percutaneous ultrasound-guided core biopsy demonstrated a periductal lymphoplasmacytic infiltration with whirling fibrosis and phlebitis (Fig. 4).

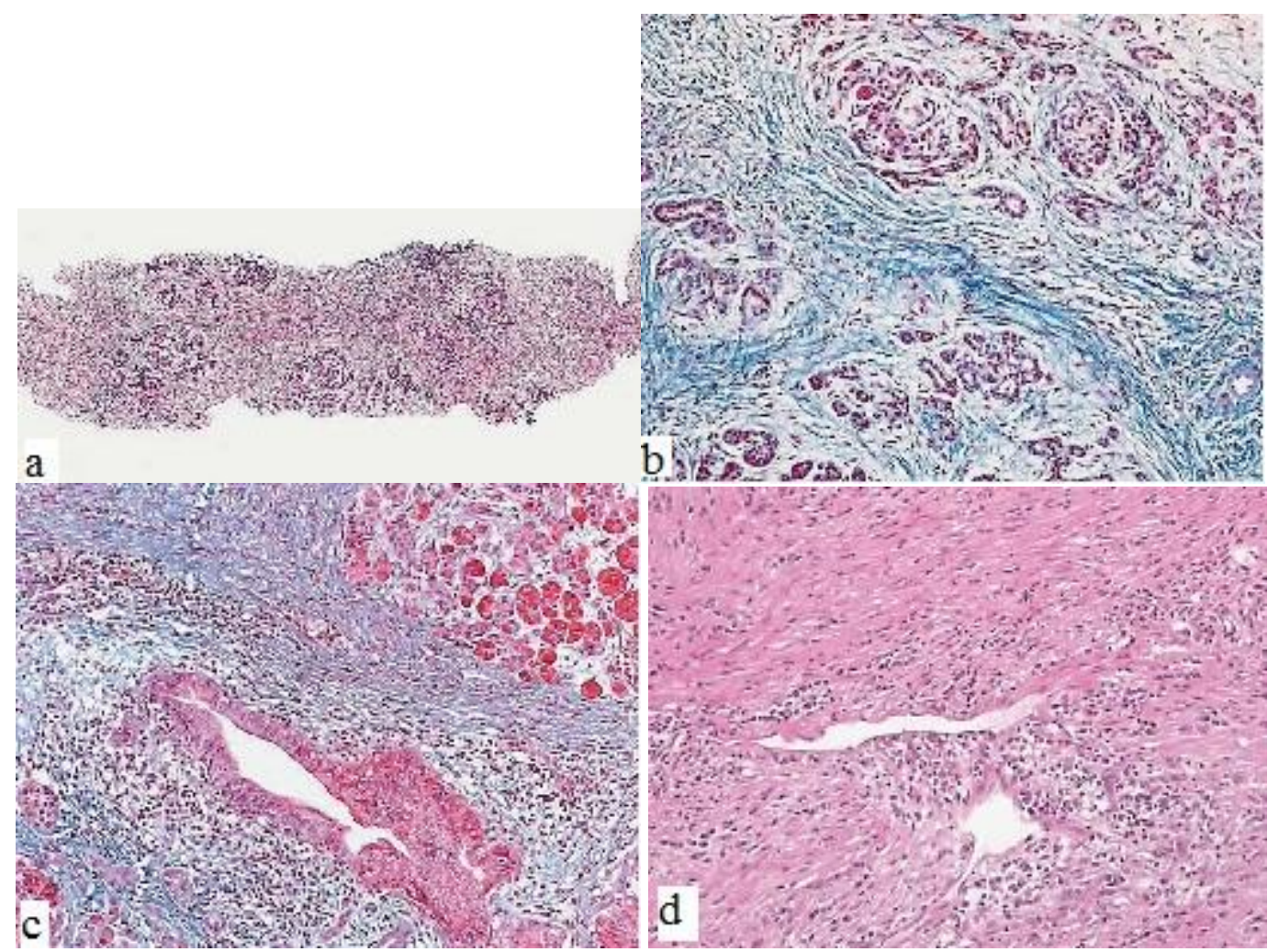

Fig. 4. Histological examination demonstrates storiform fibrosis around the atrophic lobules with a dense mononuclear cell infiltration (HE; a), fibrosis rich in collagen fibers (trichrome dye; b), periductal lymphoplasmacytic infiltration (HE; c) and venulitis (HE; d ).

Malignancy could not be excluded in 2 AIP cases because of the presence of a pancreatic mass (both involved type 2 AIP), and pancreatic head resection was performed. Histological examination of the resected specimen supported the diagnosis of AIP. In 4 cases, biopsy samples were taken from the swollen papilla of Vater during duodenoscopy; 2 of them were diagnostic of AIP; in both cases, only the pancreatic head was affected. IgG4 immunohistochemical examinations could be performed in 8 patients, $5(63 \%)$ of whom were positive (Fig. 5a). However, in the serologically negative cases, granulocytic infiltration of 
the ductal epithelial cells (GEL) was revealed besides the classical lymphoplasmacytic infiltration, i.e. IDCP was identified (Fig. 5b).

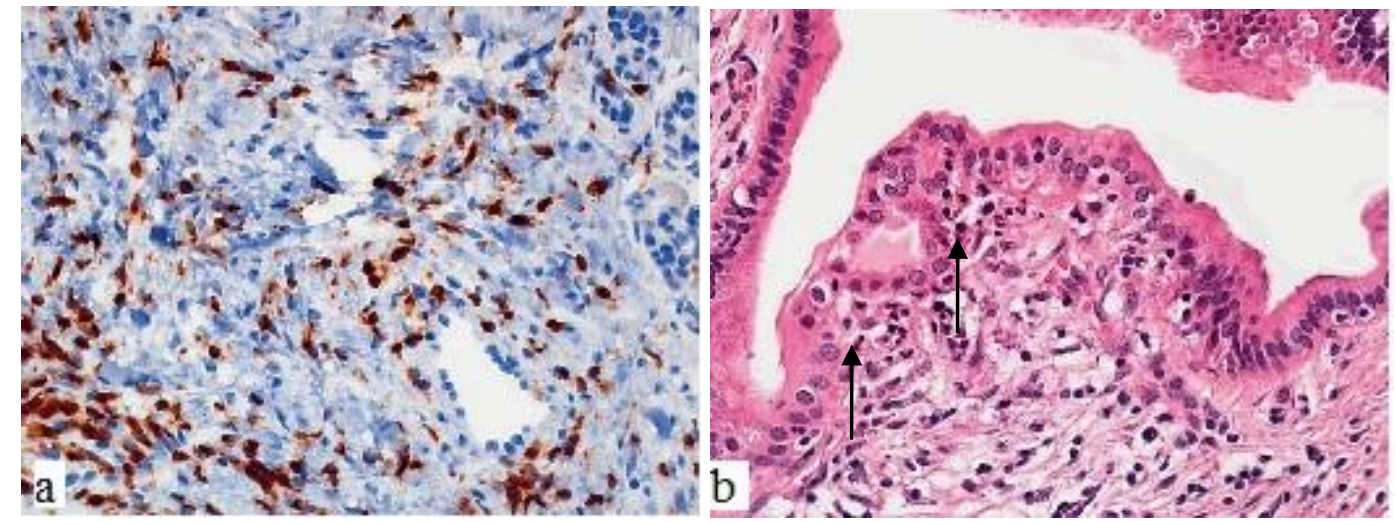

Fig. 5. Histological findings in autoimmune pancreatitis. Type 1: periductal accumulation of IgG4-positive plasma cells (HE; a). Type 2: duct with GEL (arrows, HE; b).

As concerns the demographics of the patients with the two histological types of AIP, a majority of the LPSP patients were older, while the IDCP patients were significantly younger. There was no male predominance in our IDCP patients, and an association with ulcerative colitis was common (Table 4.).

A complete response was achieved in all 15 patients during steroid therapy. The patients became asymptomatic within a short time, the elevated liver function decreased, and the enlargement of the pancreas and the narrowing of the bile duct had reversed by 4 weeks after the start of the steroid therapy (Fig. 2b). A relapse occurred in 1 patient (7\%) during the dose reduction in prednisolone, but remission was again achieved following a dose increase in steroid treatment and the administration of azathioprine as long-term immunosuppression.

TABLE 4. DEMOGRAPHICS OF THE PATIENTS WITH LYMPHOPLASMACYTIC SCLEROSING PANCREATITIS AND IDIOPATHIC DUCT CENTRIC CHRONIC PANCREATITIS

\begin{tabular}{lcc}
\hline & LPSP & IDCP \\
\hline Mean age (range) (y) & $59(37-74)$ & $34(19-56)$ \\
No. of females (cases) & $3(60 \%)$ & $2(66 \%)$ \\
Ulcerative colitis (cases) & $1(20 \%)$ & $2(66 \%)$ \\
\hline
\end{tabular}




\section{Association between autoimmune pancreatitis and systemic autoimmune diseases}

In our second study, an elevated serum IgG4 level (mean value $919 \pm 996 \mathrm{mg} / \mathrm{L}$ ) was detected in 17 (28\%) of the 61 SAID patients (Fig. 6). Ten of the 17 patients had SS (mean serum IgG4 $590 \pm 232 \mathrm{mg} / \mathrm{L}$ ) (2 cases were associated with Hashimoto's thyroiditis), while 7 (mean serum IgG4 $1388 \pm 985.5 \mathrm{mg} / \mathrm{L}$ ) were diagnosed with SLE. Two SLE patients displayed markedly elevated IgG4 levels (> $3000 \mathrm{mg} / \mathrm{L}$ ). In one case, SLE was associated with Raynaud's syndrome, while the other patient suffered from xerophthalmia and bronchial asthma. The serum IgG4 level was elevated (mean serum IgG4 $783 \pm 522 \mathrm{mg} / \mathrm{L})$ in $5(83 \%)$ of the 6 AIP patients. The patient with a normal level of IgG4 had typical pancreatic histology and his condition improved with steroid therapy. The IgG4 levels in these SLE and SS patients were not significantly different from that in the AIP patients.

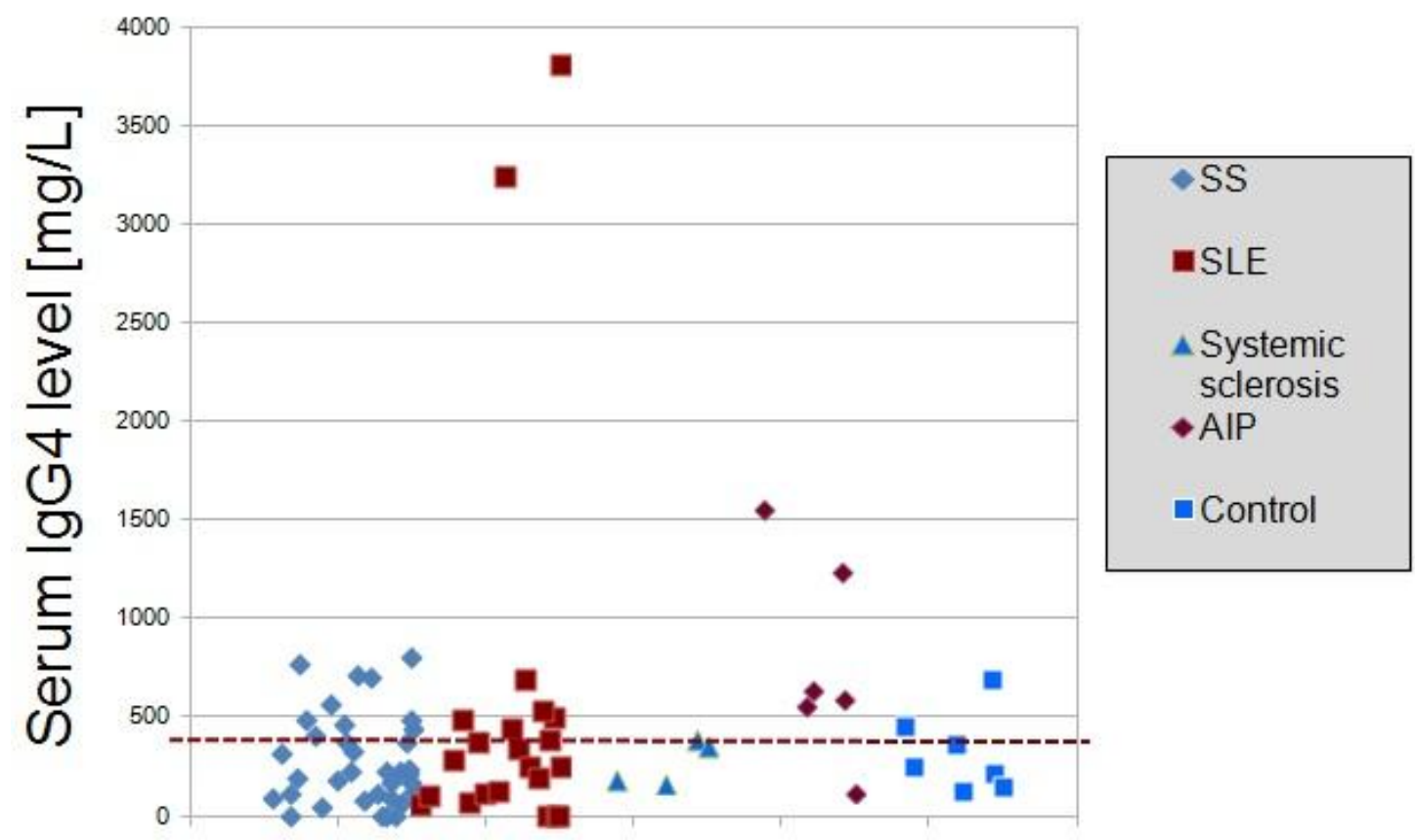

Fig. 6. Serum IgG4 levels in different systemic autoimmune diseases and autoimmune pancreatitis. Dotted line: Cutoff value $(400 \mathrm{mg} / \mathrm{L})$.

US examination revealed a normal pancreas in 11 of the 17 SAID patients with elevated serum IgG4 levels, but raised the suspicion of AIP by demonstrating a gracile 
pancreas in 2 cases (both suffered from SS), and widening of the body or the tail of pancreas, each in a further 1 patient (both suffered from SLE). However, in none of these 4 cases was AIP confirmed by an abdominal CT scan. The US examinations indicated pancreatic steatosis in 2 additional cases. None of the SAID patients had pancreatic duct dilatation.

The presence of anti-SS-A/SS-B autoantibodies and the potential relation of this to an elevated IgG4 level were examined in the patients with SS. Both anti-SS-A positivity and anti-SS-B positivity were detected in 22 patients; 7 of them exhibited an elevated IgG4 level. The anti-SS-A was positive and the anti-SS-B was negative in 9 cases; 2 of these patients had a high IgG4 level. In 4 patients with SS, neither anti-SS-A positivity, nor anti-SS-B positivity was found; an elevated IgG4 level was detected in only 1 of these cases (Table 5.).

TABLE 5. THE PRESENCE OF ANTI-SS-A/SS-B AUTOANTIBODIES AMONG SJÖGREN'S SYNDROME - PATIENTS WITH ELEVATED IgG4 LEVEL

\begin{tabular}{cccc}
\hline & \multicolumn{3}{c}{ Sjögren's syndrome } \\
\hline & SS-A positive / & SS-A positive / & SS-A negative / \\
& SS-B positive & SS-B negative & SS-B negative \\
\hline $\mathrm{IgG} 4>400 \mathrm{mg} / \mathrm{L}$ & 7 & 2 & 1 \\
\hline
\end{tabular}

\section{Improved glycemic control in pancreatic diabetes through intensive conservative insulin therapy}

During the examined 4-year period in the third study, a total of 297 patients with CP were admitted to our department, 112 of them with pancreatic DM. 30 pancreatic DM patients (24 male, 6 female, mean age: 56.4 y, range: $36-76$ y) with $\mathrm{HbA1c} \geq 7.0 \%$ were recruited: 16 cases in Group A, 8 cases in Group B, and 6 cases in Group C (Table 2.). Because of the inappropriate glycemic control $(\mathrm{HbA} 1 \mathrm{c}>9 \%)$ after the 2-year follow-up period, 4 patients were transferred into Group C. The duration of CP was over 10 years. $47 \%$ of the patients had previously undergone pancreatic surgery and $63 \%$ of them presented with calcifications in the pancreas. The etiology involved chronic alcohol abuse in $63 \%$ of the cases (Table 2.).

There was a great variety in the prior medication of the patients in Groups A and B: metformin or sulfonylurea alone; metformin and sulfonylurea in combination; sulfonylurea 
and acarbose in combination; metformin, sulfonylurea and acarbose in combination; or metformin, sulfonylurea, acarbose and glitazone in combination (Table 6.). On average, these patients had been treated with oral antidiabetics for $55 \pm 68$ months before switching to insulin. The level of HbA1c had worsened significantly by $18.1 \%$ (from $8.3 \pm 1.5 \%$ to $9.8 \pm$ $1.7 \%, \mathrm{p}<0.05)$ during this period.

TABLE 6. INITIAL TREATMENT USED IN PATIENTS WITH PANCREATIC DIABETES IN GROUPS A AND B.

\begin{tabular}{lc}
\hline Treatment & $N$ \\
\hline Metformin alone & 4 \\
Sulfonylurea alone & 12 \\
Metformin and sulfonylurea combination & 3 \\
Sulfonylurea and acarbose combination & 2 \\
Metformin, sulfonylurea and acarbose combination & 2 \\
Metformin, sulfonylurea, acarbose and glitazone combination & 1 \\
\hline
\end{tabular}

After 12 weeks, the introduction of ICT in Group A had significantly reduced the fasting plasma glucose by $29 \%$ (from $13.0 \pm 3.9$ to $9.2 \pm 2.1 \mathrm{mmol} / \mathrm{l}, \mathrm{p}<0.002$ ) (Fig. $7 \mathrm{a}$ ) and $\mathrm{HbA} 1 \mathrm{c}$ by $22 \%$ (from $9.7 \pm 1.8 \%$ to $7.6 \pm 1.4 \%$, p < 0.001 ) (Fig. $7 b$ ). Five patients had HbA1c $<7.0 \%$. By 2 years, both the blood glucose and HbA1c had further decreased significantly to $8.0 \pm 2.2 \mathrm{mmol} / \mathrm{l}(\mathrm{p}<0.001)$ and to $7.4 \pm 1.4 \%(\mathrm{p}<0.003)$, respectively. The body weight did not change significantly during the 2 years of therapy $(72.1$ vs $72.9 \mathrm{~kg}, \mathrm{p}=$ 0.708). With the exception of 1 patient who was a habitual drinker, none of the patients reported any severe hypoglycemic episode (i.e. requiring external assistance) or was hospitalized for hypoglycemia, though minor hypoglycemic attacks with good warning were documented.

After 12 weeks, the introduction of PMI twice a day in Group B had reduced the fasting plasma glucose by $12 \%$ (from $13.2 \pm 3.1$ to $11.6 \pm 2.9 \mathrm{mmol} / \mathrm{l}, \mathrm{p}=0.190$ ) (Fig. $7 a$ ) and $\mathrm{HbA} 1 \mathrm{c}$ by $10 \%$ (from $10.0 \pm 1.4 \%$ to $9.0 \pm 0.6 \%, \mathrm{p}=0.291$ ), but not significantly (Fig. $7 b)$. The blood glucose and HbA1c had improved further by 2 years $(10.2 \pm 2.2 \mathrm{mmol} / \mathrm{l}, \mathrm{p}=$ 0.07 and $8.6 \pm 0.9 \%, \mathrm{p}=0.23$, respectively), though none of the patients had a HbA1c level < 7.0\%. The body weight did not change significantly (72.7 vs $71.6 \mathrm{~kg}, \mathrm{p}=0.796)$. 
After 12 weeks, the introduction of ICT in Group C had reduced the fasting plasma glucose by $19 \%$ (from $12.2 \pm 3.3$ to $9.9 \pm 2.5 \mathrm{mmol} / \mathrm{l}, \mathrm{p}=0.127$ ) (Fig. 7a) and the level of HbA1c significantly by $13 \%$ (from $8.8 \pm 1.7 \%$ to $7.7 \pm 1.2$, p < 0.04 ) (Fig. 7b). Two patients attained $\mathrm{HbA} 1 \mathrm{c}<7.0 \%$. By 2 years, the blood glucose remained stable $(9.8 \pm 3.1 \mathrm{mmol} / \mathrm{l}, \mathrm{p}=$ $0.139)$, but HbA1c had significantly decreased further $(7.6 \pm 1.2 \%, \mathrm{p}<0.04)($ Fig. $7 a, b)$. The body weight of these patients did not change significantly during the 2 years of therapy $(77.4$ vs $79.1 \mathrm{~kg}, \mathrm{p}=0.498$ ). With the exception of 1 case on PMI therapy because of a concomitant viral infection, no severe hypoglycemic episode or hospitalization was necessary due to hypoglycemia in Groups B and C. 


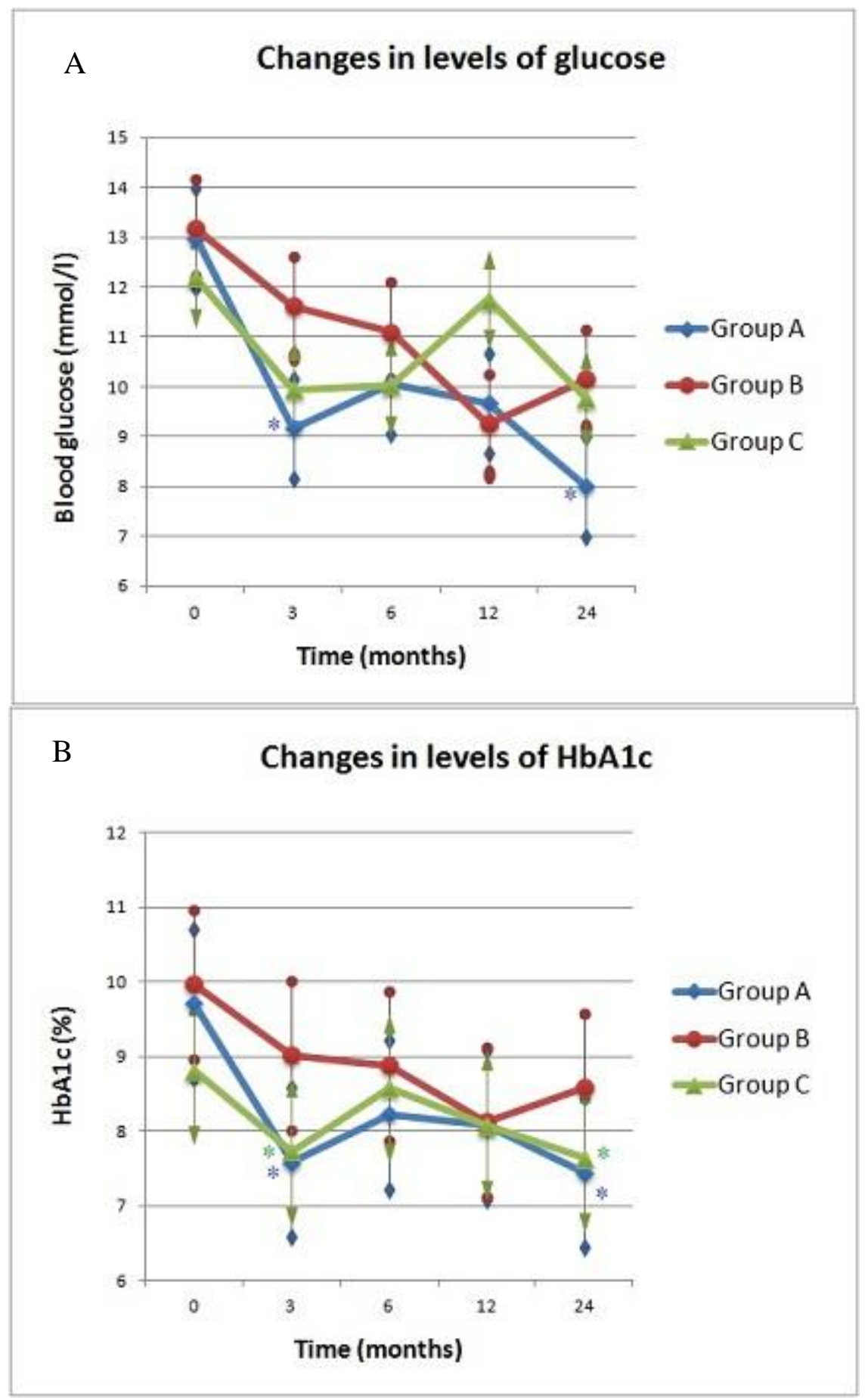

Fig. 7. Efficacy of insulin therapy in pancreatic diabetes. Changes in fasting plasma glucose (A) and $\mathrm{HbA1c}$ (B) after the introduction of intensive conservative insulin treatment (Group A) or twice daily pre-mixed insulin (Group B) instead of oral medication. The initial pre-mixed insulin therapy was switched to intensive conservative insulin treatment in Group C.

$*$ Significant difference $(\mathrm{p}<0.05)$ vs baseline. 
The daily average dose of insulin in Groups A, B and C was $30.4 \pm 11.8,29.9 \pm 12.4$ and $40.1 \pm 8.1 \mathrm{IU}$, respectively. The better glycemic control required a higher amount of insulin during ICT as compared with the initial PMI therapy in Group C (38.4 \pm 12.6 vs 40.1 $\pm 8.14 \mathrm{IU}, \mathrm{p}=0.91)$. 


\section{DISCUSSION}

\section{Autoimmune pancreatitis in Hungary}

To date, a majority of the AIP cases have been reported from Japan, and even the existence of the disease was debated in the west until comparatively recently $[42,43]$. Our study tends to confirm recent data $[6-10]$ indicating that AIP is not restricted to some specific region of the world, but also occurs in central Eastern Europe. The epidemiology of our AIP series differs from those previously reported. A nationwide study in Japan indicated that the peak age at onset was 61-65 years, and those older than 46 years accounted for $96 \%$ of the overall number of patients [44]. AIP predominantly affects men in Japan, with a male:female ratio of 2.85:1 [49]. In contrast with the Japanese data, the patients in our series were appreciably younger, with a median age at presentation of 42.7 years, and the male:female ratio was 1.13:1. Our patients were even younger than the AIP patients reported in recent UK, European and US series, where the median age at presentation was 53, 56 and 62.5 years, respectively [7, 9, 45]. Moreover, there was a male preponderance $(100,66$ and $65 \%$ were male in the UK, European and US studies, respectively), in agreement with the reports from East Asia. In support of our study, a lower median age (43.4 years) at presentation was also reported in an Italian study [6], although they noted a male predominance $(62 \%)$.

The results of recent European and American studies have led to AIP being subclassified into types 1 and 2 [9 - 11]. Type 1, LPSP, classically described in Japan, primarily affects elderly males [3, 5, 44]. Type 2, IDCP, which frequently occurs in Europe, is seen in younger patients and does not display a gender predilection $[9,10]$. There have been only 2 studies where the incidence of type 2 AIP was reported: $37.5 \%$ in a European study [10] and $27.5 \%$ in a US study [46]. In our series, $37.5 \%$ of the AIP cases with available results of pancreas histology proved to be of type 2 AIP and a further 3 patients had 'probable' type 2 AIP, based on the imaging data, the normal serum IgG4 level and the response to steroids. The somewhat higher incidence of type 2 AIP in our series may explain the younger age and the female predominance among our AIP patients. Nevertheless, a male preponderance was not observed among our type 1 AIP patients either. 
An association of AIP with other autoimmune diseases was reported in 35-56\% of the Japanese cases [3, 5, 44], which is in accord with our Hungarian series (47\%). However, in our series, the nature of the autoimmune diseases differed from that reported in previous studies [3, 5, 7, 45]. Inflammatory bowel disease was the most frequent (5 of 8) associated autoimmune disease, confirming the finding in the Italian study [6]. This can be explained by the pronounced occurrence of type 2 AIP in our series.

It was earlier demonstrated that the serum IgG4 level is a highly sensitive (95\%) and specific (97\%) indicator in the diagnosis of AIP [15]. We observed elevated serum IgG4 levels in only $62 \%$ of our patients, a finding in agreement with a report from the US, where the serum IgG4 level was elevated in $71 \%$ of the patients [36]. This emphasizes that the detection of a normal IgG4 level does not exclude the presence of AIP. About $20 \%$ of AIP patients do not have elevated serum IgG4 levels. These cases may include IDCP, LPSP with low activity, or sclerosing pancreatitis other than LPSP or IDCP [47].

Certain histological features in the pancreas are diagnostic of AIP [1, 36]. Eight of our patients exhibited a discrete mass in the pancreas. The ultrasound-guided pancreatic core needle biopsies in 5 of these patients were all diagnostic, demonstrating a lymphoplasmacytic infiltration of the pancreas. One ultrasound-guided pancreatic fine-needle aspiration was not diagnostic. Four patients had biopsies of the swollen papilla and in 2 of them a lymphoplasmacytic infiltration was noted histologically. The major duodenal papilla is a conduit between the duodenum and the pancreatobiliary system, and its pathological examination may reflect underlying pancreatobiliary disorders. Previous studies have demonstrated a 55-80\% sensitivity of positive IgG4 immunostaining of the major papilla [48]. Our finding was similar to this result. AIP was manifested as a focal enlargement of the pancreatic head in the 2 patients with positive IgG4 immunostaining of the major papilla. Furthermore, the postoperative histological examination of the resected pancreatic head mass in another focal AIP patient revealed the typical lymphoplasmacytic infiltration of the papilla of Vater, although IgG4 immunostaining was negative. The other 2 patients with negative IgG4 immunostaining of the major papilla had the diffuse form of AIP, and 1 of them had probable IDCP.

The response to steroid therapy is a HISORt criterion in the diagnosis of AIP. In agreement with previous reports [1, 3, 6, 7, 45], a rapid symptomatic response and improvements in liver biochemistry and morphology were observed 4 weeks after the start of 
steroid therapy. However, in contrast with the earlier reports, recurrence was rarely encountered. In our series, only 1 patient had a recurrence. The long-term follow-up will disclose the final number of patients who relapse.

Further work is required to determine the distribution and characteristics of type 2 AIP in the Hungarian population.

\section{Association between autoimmune pancreatitis and systemic autoimmune diseases}

The study has demonstrated that the serum IgG4 level may be elevated in SAIDs, without the presence of AIP.

AIP can be complicated by a variety of extrapancreatic lesions, which appear synchronously or metachronously with the pancreatic lesion, share the same pathological conditions, and show a favorable response to glucocorticosteroid therapy, characteristics indicative of a common pathophysiological background. Among the variety of extrapancreatic diseases, lachrymal and salivary gland lesions are some of the most frequent, found in 23$39 \%$ of patients with AIP $[49,50]$. Extrapancreatic lesions may mimic or be misdiagnosed as primary lesions of the corresponding organs, e.g. lachrymal and salivary gland lesions for SS. It is therefore necessary to differentiate between IgG4-related diseases and inherent diseases of the corresponding organ. When the pancreatic lesion is obscured, it may be difficult to detect these presumably IgG4-related extrapancreatic lesions [5].

IgG4 is the rarest of the $4 \operatorname{IgG}$ subclasses in humans, with an incidence of about $4 \%$. IgG antibodies are predominantly involved in the secondary immune response; complement activation is possibly their most important biological function. The main role of IgG4 is presumably to protect against the biological effects of the complement-fixing IgG subclasses and to act in parasitic infestation or various forms of atopy [51 - 53]. Serum IgG4 levels are frequently and significantly elevated in AIP patients [16] and an elevated level of serum IgG4 has been included among the laboratory criteria for the diagnosis of AIP [5, 36]. AIP patients with 3 extrapancreatic lesions have been reported to have significantly higher IgG4 levels than those lacking such lesions [49]. The optimal cutoff value for discriminating AIP patients 
with extrapancreatic lesions from those without was demonstrated on the basis of receiver operator characteristic curves to be $2200 \mathrm{mg} / \mathrm{L} \mathrm{[17].}$

The serum IgG4 level was measured in 61 SAID patients in our study, $28 \%$ of whom proved to have an elevated serum level of IgG4. However, none of them could be diagnosed with AIP according to the HISORt criteria. What could be the reason for this?

One explanation is the composition of our patient cohort. In Japan, AIP predominantly affects men, with a male:female ratio of 2.85:1 [49]. Moreover, there was a male preponderance in the UK, European and US studies (100\%, 66\% and 65\% male, respectively), similar by as in reports from Japan [7, 9, 45, 54]. In contrast, there was only 1 male in our patient population.

Lachrymal and salivary lesions associated with AIP were previously considered to be complications of SS. However, in contrast with those accompanying SS, the lachrymal and salivary gland lesions associated with AIP yield negative results for anti-SS-A/SS-B autoantibodies and show numerous IgG4-positive plasma cell infiltrations in the affected tissues. These lesions are currently thought to correspond to Mikulicz's disease [55]. The explanation for our negative results may be that there was only one patient with negative SSA/SS-B autoantibodies in our study group.

Another point is that autoantibodies against FceRI $\alpha$ are detected in the sera of patients with different autoimmune diseases (such as SLE, dermatomyositis, pemphigus and pemphigoid); these antibodies are from subclasses $\operatorname{IgG} 2$ and $\mathrm{IgG} 4$, but they are functionally inactive [56]. In our study, elevated IgG4 levels were found in 7 patients treated for SLE.

Moreover, our 17 SAID patients with elevated IgG4 levels included 6 who suffered from different concomitant diseases which could cause the increase in the serum level of IgG4. In 1 patient, nodular sclerosis Hodgkin's lymphoma was diagnosed histologically. Hodgkin's lymphoma cells frequently express interleukin 13 and its receptor. Besides exerting several effects on B cells (e.g. promotion of their survival and proliferation), interleukin 13 switches the Ig class to IgG4 and IgE [57]. In another patient, bullous pemphigoid was identified, which is among the most common blistering autoimmune skin lesions. One of the features of the disease is the presence of autoantibodies against hemidesmosomal antigens (i.e. bullous pemphigoid antigens 1 and 2) in the serum and in affected areas of the skin. The major types of these autoantibodies are IgG4 and IgE [58]. In a third patient, cutaneous lymphocytic vasculitis was diagnosed, which could also explain the serum IgG4 elevation [59]. In 2 patients, 
the underlying disease was accompanied by Hashimoto's thyroiditis, which can elevate the IgG4 level since thyroglobulin autoantibodies are from subclasses IgG2 and IgG4 [60]. There was also 1 patient with bronchial asthma, in which disease elevated titers of IgG4 can be found [61].

Finally, SS was diagnosed in the remaining 4 patients, one of whom was seronegative, while the others were seropositive. The elevated serum IgG4 level in patients with seronegative SS may possibly be explained by the presence of Mikulicz's disease [62]. Furthermore, an elevated serum IgG4 level has also been reported in SS [63].

However, not all AIP patients display elevated serum IgG and IgG4 levels. IgG4negative AIP patients seem to occur more frequently in Europe [47]. Furthermore, some AIP cases improve spontaneously [5]. Hence, it cannot be ruled out that our SAID cohort included AIP patients who were not diagnosed by the measurement of serum IgG4 or in whom the morphology of the pancreas had already normalized by the time of our examination.

\section{Improved glycemic control in pancreatic diabetes through intensive conservative insulin therapy}

The study has demonstrated that long-term improvement of glycemic control was achieved without the risk of hypoglycemia in our cohort of pancreatic DM patients through the use of insulin therapy.

No evidence-based study relating to treatment practice in pancreatic DM has been reported to date. All the large clinical trials, including UKPDS and DCCT, specifically excluded patients with pancreatic DM [34, 35]. Some authors suggest a trial of oral antidiabetic agents followed by insulin therapy when the need arises [64, 65]. However, insulin sensitizers (biguanides and glitazones) and the carbohydrate absorption inhibitor $\alpha$ glucosidase should be avoided in pancreatic DM, since the major pathogenetic defect is a lack of insulin and because of the coexisting maldigestion and consequent leanness. Furthermore, their side-effects (bloating, diarrhea and abdominal pain) would add to the similar symptoms caused by CP. Since patients with pancreatic DM may occasionally be capable of insulin secretion, sulfonylureas may initially be of benefit. However, CP is a progressive disorder and the use of sulfonylureas can accelerate the exhaustion of beta-cells. Indeed, in our patients 
who had received sulfonylurea medication, glycemic control became inappropriate much earlier than secondary sulfonylurea failure develops in type 2 DM [66]. Furthermore, sulfonylurea may cause hypoglycemia and is often contraindicated due to the accompanying liver disease [22]. Overall, the application of oral antidiabetic drugs in pancreatic DM is generally not recommended.

Despite the facts mentioned above, the indications for the previous introduction of oral antidiabetic drugs to our cohort can be explained retrospectively by the following features: (1) the plasma glucose level was only slightly increased, to a level which is usually normalized by oral antidiabetic drugs in everyday practice, (2) the fear of severe hypoglycemia, (3) undiscovered pancreatic disease or the undetected association between pancreatic disease and DM.

The primary hormonal abnormality in pancreatic DM is decreased insulin secretion [20 - 22]. Moreover, pancreatic DM is considered to be a result not merely of impaired insulin production, but also of coexisting hepatic insulin resistance and alterations in insulin action [32, 67]. The loss of counterregulatory hormones from the pancreas (e.g. somatostatin and glucagon) makes it difficult to achieve good glycemic control in pancreatic DM. The maldigestion of carbohydrates due to the coexisting pancreatic exocrine insufficiency, the concomitant alcohol consumption and hepatic disease, the lack of compliance with the prescribed diet and/or medical therapy, and the enhanced intestinal transit further hamper the appropriate glycemic treatment of these patients [22]. These factors may lead to frequent, severe and unpredictable hypoglycemic episodes that may prove lethal in patients on insulin $[24,68]$. However, in contrast with previous observations [24], our study revealed that severe hypoglycemia was not a common problem in patients with pancreatic DM treated with insulin. Furthermore, the frequency of hypoglycemia in patients who continued to consume alcohol was clearly higher than in patients who had stopped drinking [24]. Accordingly, ICT should be administered only to selected patients who do not consume alcohol and display compliance.

Patients with pancreatic DM exhibit deficiencies in both basal and postprandial insulin secretion. To mimic physiological insulin secretion, the supplementation of prandial and basal insulin levels is important. The clinical efficacy of a multiple insulin injection regimen in pancreatic DM has been reported [69]. It is suggested that insulin therapy in pancreatic DM should be started as early as possible, when the beta-cells are still capable of secreting insulin $[70,71]$. The introduction of early insulin therapy promotes the maximal preservation of the 
patient's own insulin secretion. The preserved endogenous insulin secretion can adapt to the changing plasma glucose level, with the consequence that these patients are less prone to hypoglycemia, and glycemic control is more stable.

The administration of long-acting insulin twice a day is usually not recommended in pancreatic DM, because of the possibility of interference and the danger of severe hypoglycemia [72]. However, as long as the beta-cells are capable of secreting insulin, glycemic control may be accomplished by twice a day administration of intermediate or PMI. Indeed, in our selected cases (Group B), good glycemic control was achieved without the risk of hypoglycemia by means of the twice a day administration of PMI. However, to accomplish the recommended glycemic control in Group C, intensified insulin therapy was needed instead of twice daily PMI. This regime preserves the endogenous insulin secretion, and can easily be adapted to the daily activities in cooperating patients.

All of our patients demonstrated a reduced $\mathrm{HbAlc}$ level after the induction of ICT or PMI (Fig. 7b). The extents of reduction of HbA1c after 3 months in Groups A, B and C were 22, 10 and 13\%, respectively. Furthermore, stable long-term control of the blood glucose and HbA1c levels was attained with insulin therapy by 2 years. 


\section{NEW RESULTS ESTABLISHED IN THE THESIS}

\section{Autoimmune pancreatitis in Hungary}

1. AIP is present and increasingly recognized in the Hungarian population.

2. Various previously reported findings on the clinical presentation and management of AIP were confirmed in our series.

3. AIP with GEL was relatively frequent among our patients; these patients were younger, and presented a female preponderance and a high coincidence of ulcerative colitis. Performance of a percutaneous biopsy is strongly recommended for the diagnosis of type 2 AIP.

4. The response to steroid therapy was excellent in our AIP patients.

\section{Association between autoimmune pancreatitis and systemic autoimmune diseases}

1. The serum IgG4 level may be elevated in SAIDs, but as a consequence of the concomitant SAID rather than of AIP.

2. The determination of serum IgG4 does not seem to be suitable for the differentiation between IgG4-related diseases and SAIDs.

\section{Improved glycemic control in pancreatic diabetes through intensive conservative insulin therapy}

1. Oral medication becomes insufficient early in pancreatic DM.

2. The best long-term glycemic control can be achieved without the risk of hypoglycemia through intensified insulin therapy and in selected cases with PMI. 


\section{SUMMARY}

BACKGROUND: Autoimmune pancreatitis (AIP) is a special type of chronic pancreatitis (CP), which displays clinical, morphological, serological, radiological and in particular histological features that are distinct from those of other types of CP. Immunological examinations in AIP patients have demonstrated high incidences of hypergammaglobulinemia (43\%), increased serum levels of immunoglobulin G ( $\operatorname{IgG}$ ) (62$80 \%)$ and IgG4 (68-92\%), and the presence of antinuclear antibodies (40-64\%) and rheumatoid factor (25\%). The immunological and histological features of AIP and the glucocorticosteroid responsiveness suggest an autoimmune mechanism for the development of the disease. CP can cause pancreatic diabetes mellitus (DM), which develops from the impairment of the pancreatic endocrine function due to the progression of a pancreatic disease. The pathomechanism and clinical features of pancreatic DM differ from those of types 1 and $2 \mathrm{DM}$, and the principles of its treatment may also differ. However, there appears to be a lack of consensus regarding the management of patients with pancreatic DM. Our aims were (i) to assess the characteristics of AIP cases in Hungary; (ii) to assess the presence of AIP in various systemic autoimmune diseases (SAIDs) and (iii) to evaluate the effectivity of insulin therapy in patients with pancreatic DM.

MATERIALS AND METHODS: For these purposes we carried out three different clinical studies. In our first study, patients diagnosed with AIP between May 1, 2008 and October 30, 2010 and treated in Hungarian gastroenterological centers were enrolled. Patient data relating to the clinical, morphological, serological, radiological and histological features and the response to steroid therapy were retrieved from the medical documentation and follow-up data were collected prospectively. The results were compared with those of other European, Japanese and American studies. In our second study, which was performed in 2010, serum samples were obtained from 61 patients with various SAIDs. Sera were additionally taken from 7 age- and sex-matched healthy subjects, and 6 patients with AIP. Patients with a serum IgG4 level of $>400 \mathrm{mg} / \mathrm{L}$ were examined by a gastroenterologist, the clinical and laboratory data were reviewed and abdominal ultrasonography or computed tomography was performed. The results of the three groups were compared and evaluated. In the third study, pancreatic DM patients with $\mathrm{HbA1c} \geq 7.0 \%$ were recruited between January 1, 2007 and 
December 31, 2010. Depending on the antidiabetic therapy administered up to the time of recruitment, the patients were divided into three groups. In Groups A and B, the baseline antidiabetic therapy was oral medication, while in Group $\mathrm{C}$ it was pre-mixed insulin (PMI). Because of the inappropriate glycemic control, the initial oral medication was switched to intensive conservative insulin treatment (ICT) in Group A and to twice daily PMI in Group B. Poor compliance or the loss of sight was the reason for the change to PMI instead of ICT in Group B. The initial PMI therapy was switched to ICT in Group C. The changes in HbA1c, fasting plasma glucose, body weight and hypoglycemic events were followed from baseline to 2 years.

RESULTS AND CONCLUSIONS: The present studies have demonstrated that AIP is present and increasingly recognized in the Hungarian population. Various previously reported findings on the clinical presentation and management of AIP were confirmed in our series. AIP with granulocyte epithelial lesions was relatively frequent among our patients; these patients were younger, and presented a female preponderance and a high coincidence of ulcerative colitis. Performance of a percutaneous biopsy is strongly recommended for the diagnosis of type 2 AIP. The response to steroid therapy was excellent in our AIP patients. Our second study allowed the conclusion that the serum IgG4 level may be elevated in SAIDs, but as a consequence of the concomitant SAID rather than of AIP. The determination of serum IgG4 does not seem to be suitable for the differentiation between IgG4-related diseases and SAIDs. The third study suggested that oral medication may become insufficient early in pancreatic DM. The best long-term glycemic control can be achieved without the risk of hypoglycemia through intensified insulin therapy and in selected cases with PMI. 


\section{ACKNOWLEDGMENTS}

I would like to express my deepest appreciation to Prof. Dr. Tibor Wittmann, the head of the First Department of Internal Medicine, who gave me the opportunity to start working at the institute, and Dr. habil. László Czakó, my tutor for his support and guidance; without them this work could not be done.

I am grateful to Prof. Dr. Péter Hegyi and his research group for their support.

I would like to express my gratitude to Dr. József Kaszaki, my tutor at Institute of Surgical Research, who introduced me into the experimental work and to his colleagues: Gabriella Varga, Dr. Dániel Érces, Istvánné Fekete, Andrea Bús, Csilla Mester, Nikolett Beretka, Ildikó László, Károly Tóth and Kálmán Vas for their contribution of time and ideas.

I would also like to thank my colleagues from the First Department of Internal Medicine and co-authors for giving me supportive advices in my work and helping with patient screening.

I dedicate the thesis to my family for their long-standing and never ending patience, support and love. 


\section{REFERENCES}

1. Detlefsen S, Drewes AM. Autoimmune pancreatitis. Scand J Gastroenterol. 2009; 44:1391-1407.

2. Czakó L. Autoimmun pancreatitis: Aluldiagnosztizált kórkép? Lege Artis Med 2006; 6:505-510.

3. Shimosegawa T, Kanno A. Autoimmune pancreatitis in Japan: overview and perspective. J Gastroenterol. 2009; 44:503-517.

4. Park DH, Kim MH, Chari ST. Recent advances in autoimmune pancreatitis. Gut. 2009; 12:1680-1689.

5. Okazaki K, Kawa S, Kamisawa T, Ito T, Inui K, Irie H, Irisawa A, Kubo K, Notohara K, Hasebe O, Fujinaga Y, Ohara H, Tanaka S, Nishino T, Nishimori I, Nishiyama T, Suda K, Shiratori K, Shimosegawa T, Tanaka M. Japanese clinical guidelines for autoimmune pancreatitis. Pancreas 2009; 38:849-866.

6. Frulloni L, Scattolini C, Falconi M, Zamboni G, Capelli P, Manfredi R, Graziani R, D'Onofrio M, Katsotourchi AM, Amodio A, Benini L, Vantini I. Autoimmune pancreatitis: differences between the focal and diffuse forms in 87 patients. Am J Gastroenterol. 2009; 9:2288-2294.

7. Church NI, Pereira SP, Deheragoda MG, Sandanayake N, Amin Z, Lees WR, Gillams A, Rodriguez-Justo M, Novelli M, Seward EW, Hatfield AR, Webster GJ. Autoimmune pancreatitis: clinical and radiological features and objective response to steroid therapy in a UK series. Am J Gastroenterol. 2007; 102:2417-2425.

8. Löhr JM, Faissner R, Koczan D, Bewerunge P, Bassi C, Brors B, Eils R, Frulloni L, Funk A, Halangk W, Jesenofski R, Kaderali L, Kleeff J, Krüger B, Lerch MM, Lösel R, Magnani M, Neumaier M, Nittka S, Sahin-Tóth M, Sänger J, Serafini S, Schnölzer M, Thierse HJ, Wandschneider S, Zamboni G, Klöppel G. Autoantibodies against the exocrine pancreas in autoimmune pancreatitis: gene and protein expression profiling and immunoassays identify pancreatic enzymes as a major target of the inflammatory process. Am J Gastroenterol. 2010; 105:2060-2071.

9. Zamboni G, Lüttges J, Capelli P, Frulloni L, Cavallini G, Pederzoli P, Leins A, Longnecker D, Klöppel G. Histopathological features of diagnostic and clinical relevance 
in autoimmune pancreatitis: a study on 53 resection specimens and 9 biopsy specimens. Virchows Arch. 2004; 445:552-563.

10. Klöppel G, Detlefsen S, Chari ST, Longnecker DS, Zamboni G. Autoimmune pancreatitis: the clinicopathological characteristics of the subtype with granulocytic epithelial lesions. $J$ Gastroenterol. 2010; 45:787-793.

11. Notohara K, Burgart LJ, Yadav D, Chari S, Smyrk TC. Idiopathic chronic pancreatitis with periductal lymphoplasmacytic infiltration: clinicopathologic features of 35 cases. Am J Surg Pathol. 2003; 27:1119-1127.

12. Yoshida K, Toki F, Takeuchi T, Watanabe S, Shiratori K, Hayashi N. Chronic pancreatitis caused by an autoimmune abnormality. Proposal of the concept of autoimmune pancreatitis. Dig Dis Sci 1995; 40:1561-1568.

13. Kamisawa T, Okamoto A. Autoimmune pancreatitis: proposal of IgG4-related sclerosing disease. J Gastroenterol. 2006; 41:613-625.

14. Ectors N, Maillet B, Aerts R, Geboes K, Donner A, Borchard F, Lankisch P, Stolte M, Lüttges J, Kremer B, Klöppel G: Non-alcoholic duct destructive chronic pancreatitis. Gut. 1997; 41:263-268.

15. Hamano H, Kawa S, Horiuchi A, Unno H, Furuya N, Akamatsu T, Fukushima M, Nikaido T, Nakayama K, Usuda N, Kiyosawa K. High serum IgG4 concentrations in patients with sclerosing pancreatitis. N Engl J Med 2001; 344:732-738.

16. Choi EK, Kim MH, Lee TY, Kwon S, Oh HC, Hwang CY, Seo DW, Lee SS, Lee SK. The sensitivity and specificity of serum immunoglobulin $\mathrm{G}$ and immunoglobulin G4 levels in the diagnosis of autoimmune chronic pancreatitis: Korean experience. Pancreas 2007; 35: $156-161$.

17. Kamisawa T, Imai M, Egawa N, Tsuruta K, Okamoto A. Serum IgG4 levels and extrapancreatic lesions in autoimmune pancreatitis. Eur J Gastroenterol Hepatol 2008; 20: 1167-1170.

18. Okazaki K, Uchida K, Koyabu M, Miyoshi H, Takaoka M. Recent advances in the concept and diagnosis of autoimmune pancreatitis and IgG4-related disease. $J$ Gastroenterol 2011; 46: 277-288.

19. Kamisawa T, Okazaki K, Kawa S, Shimosegawa T, Tanaka M. Japanese consensus guidelines for management of autoimmune pancreatitis: III. Treatment and prognosis of AIP. J Gastroenterol 2010; 45: 471-477. 
20. Owyang C. Endocrine changes in pancreatic insufficiency. In: Go VLW, Di Magno EP, editors. The pancreas: biology, pathobiology and diseases. New York: Raven Press; 1993. p. 803-813.

21. Angelopoulos N, Dervenis C, Goula A, Rombopoulos G, Livadas S, Kaltsas D, Kaltzidou V, Tolis G. Endocrine pancreatic insufficiency in chronic pancreatitis. Pancreatology 2005; 5:122-131.

22. Czakó L, Hegyi P, Rakonczay Z, Wittmann T, Otsuki M. Interactions between the endocrine and exocrine pancreas and its clinical relevance. Pancreatology 2009; 9:351359.

23. American Diabetes Association. Diagnosis and classification of diabetes mellitus. Diabetes Care 2007; 30:S42-47.

24. Ito T, Otsuki M, Igarashi H, Kihara Y, Kawabe K, Nakamura T, Fujimori N, Oono T, Takayanagi R, Shimosegawa T; Research Committee of Intractable Diseases of the Pancreas. Epidemiological study of pancreatic diabetes in Japan in 2005. A nationwide study. Pancreas 2010; 39:829-835.

25. Malka D, Hammel P, Sauvanet A, Rufat P, O'Toole D, Bardet P, Belghiti J, Bernades P, Ruszniewski P, Lévy P. Risk factors of diabetes mellitus in chronic pancreatitis. Gastroenterology 2000; 119:1324-1332.

26. Mohan V, Barman KK, Rajan VS, Chari ST, Deepa R. Natural history of endocrine failure in tropical chronic pancreatitis: a longitudinal follow-up study. J Gastroenterol Hepatol 2005; 20:1927-1934.

27. Hardt PD, Brendel MD, Kloer HU, Bretzel RG. Is pancreatic diabetes (type 3c diabetes) underdiagnosed and misdiagnosed? Diabetes Care 2008; 31(Suppl. 2):S165-169.

28. Ewald N, Kaufmann C, Raspe A, Kloer HU, Bretzel RG, Hardt PD. Prevalence of diabetes mellitus secondary to pancreatic diseases (type 3c). Diabetes Metab Res Rev 2012; 28:338-342.

29. Donowitz M, Hendler R, Spiro HM, Binder HJ, Felig P. Glucagon secretion in acute and chronic pancreatitis. Ann Intern Med 1975; 83:778-781.

30. Valenzuela JE, Taylor IL, Walsh JH. Pancreatic polypeptide response in patients with chronic pancreatitis. Dig Dis Sci 1979; 24:862-864. 
31. Govindarajan M, Mohan V, Deepa R, Ashok S, Pitchumoni CS. Histopathology and immunohistochemistry of pancreatic islets in fibrocalculous pancreatic diabetes. Diabetes Res Clin Pract 2001; 51:29-38.

32. Andersen DK. Mechanisms and emerging treatments of the metabolic complications of chronic pancreatitis. Pancreas 2007; 35:1-15.

33. Price S, Cole D, Alcolado JC. Diabetes due to exocrine pancreatic disease - a review of patients attending a hospital-based diabetes clinic. $Q$ J Med 2010; 103:759-763.

34. Nathan DM, Buse JB, Davidson MB, Heine RJ, Holman RR, Sherwin R, Zinman B; American Diabetes Association; European Association for the Study of Diabetes. Medical management of hyperglycaemia in type 2 diabetes mellitus: a consensus algorithm for the initiation and adjustment of therapy: a consensus statement from the American Diabetes Association and the European Association for the study of diabetes. Diabetologia 2009; 52:17-30.

35. European Diabetes Policy Group. A desktop guide to type 1 (insulin-dependent) diabetes mellitus. Diab Med 1998; 1999:253-266.

36. Chari ST, Smyrk TC, Levy MJ, Topazian MD, Takahashi N, Zhang L, Clain JE, Pearson RK, Petersen BT, Vege SS, Farnell MB. Diagnosis of autoimmune pancreatitis: the Mayo Clinic experience. Clin Gastroenterol Hepatol 2006; 4:1010-1016.

37. Vitali C, Bombardieri S, Jonsson R, Moutsopoulos HM, Alexander EL, Carsons SE, Daniels TE, Fox PC, Fox RI, Kassan SS, Pillemer SR, Talal N, Weisman MH. Classification criteria for Sjögren's syndrome: a revised version of the European criteria proposed by the American-European Consensus Group. Ann Rheum Dis 2002; 61:554-558.

38. Gill JM, Quisel AM, Rocca PV, Walters DT. Diagnosis of systemic lupus erythematosus. Am Fam Physician 2003; 68:2179-2186.

39. Aletaha D, Neogi T, Silman AJ, Funovits J, Felson DT, Bingham CO, Birnbaum NS, Burmester GR, Bykerk VP, Cohen MD, Combe B, Costenbader KH, Dougados M, Emery P, Ferraccioli G, Hazes JM, Hobbs K, Huizinga TW, Kavanaugh A, Kay J, Kvien TK, Laing T, Mease P, Ménard HA, Moreland LW, Naden RL, Pincus T, Smolen JS, Stanislawska-Biernat E, Symmons D, Tak PP, Upchurch KS, Vencovský J, Wolfe F, Hawker G. 2010 Rheumatoid arthritis classification criteria: an American College of Rheumatology/European League Against Rheumatism collaborative initiative. Arthritis Rheum 2010; 62:2569-2581. 
40. Walker JG, Pope J, Baron M, Leclercq S, Hudson M, Taillefer S, Edworthy SM, Nadashkevich O, Fritzler MJ. The development of systemic sclerosis classification criteria. Clin Rheumatol 2007; 26:1401-1409.

41. DiMagno MJ, DiMagno EP. Chronic pancreatitis. Curr Opin Gastroenterol 2010; 26:490498.

42. Pearson RK, Longnecker DS, Chari ST, Smyrk TC, Okazaki K, Frulloni L, Cavallini G. Controversies in clinical pancreatology. Autoimmune pancreatitis: does it exist? Pancreas $2003 ; 27: 1-13$.

43. Varadarajulu S, Cotton PB: Autoimmune pancreatitis: is it relevant in the west? Gastroenterology 2003; 125:1557.

44. Nishimori I, Tamakoshi A, Otsuki M: Prevalence of autoimmune pancreatitis in Japan from a nationwide survey in 2002. J Gastroenterol 2007; 42(suppl XVIII):6-8.

45. Raina A, Yadav D, Krasinskas AM, McGrath KM, Khalid A, Sanders M, Whitcomb DC, Slivka A: Evaluation and management of autoimmune pancreatitis: experience at a large US center. Am J Gastroenterol 2009; 104:2295-2306.

46. Sah RP, Chari ST, Pannala R, Sugumar A, Clain JE, Levy MJ, Pearson RK, Smyrk TC, Petersen BT, Topazian MD, Takahashi N, Farnell MB, Vege SS: Differences in clinical profile and relapse rate of type 1 versus type 2 autoimmune pancreatitis. Gastroenterology 2010; 139:140-148.

47. Kamisawa T, Takuma K, Tabata T, Inaba Y, Egawa N, Tsuruta K, Hishima T, Sasaki T, Itoi T: Serum IgG4-negative autoimmune pancreatitis. J Gastroenterol 2011; 46:108-116.

48. Kim MH, Moon SH, Kamisawa T: Major duodenal papilla in autoimmune pancreatitis. Dig Surg 2010; 27:110-114.

49. Hamano H, Arakura N, Muraki T, Ozaki Y, Kiyosawa K, Kawa S. Prevalence and distribution of extrapancreatic lesions complicating autoimmune pancreatitis. $J$ Gastroenterol 2006; 41:1197-1205.

50. Naitoh I, Nakazawa T, Ohara H, Ando T, Hayashi K, Tanaka H, Okumura F, Miyabe K, Yoshida M, Sano H, Takada H, Joh T. Clinical significance of extrapancreatic lesions in autoimmune pancreatitis. Pancreas 2010; 39: e1-e5.

51. Nirula A, Glaser SM, Kalled SL, Taylor FR. What is IgG4? A review of the biology of a unique immunoglobulin subtype. Curr Opin Rheumatol 2011; 23:119-124. 
52. van der Zee JS, van Swieten P, Aalberse RC. Inhibition of complement activation by IgG4 antibodies. Clin Exp Immunol 1986; 64:415-422.

53. Aalberse RC, Schuurman J. IgG4 breaking the rules. Immunology 2002; 105:9-19.

54. Czakó L, Gyökeres T, Topa L, Sahin P, Takács T, Vincze A, Dubravcsik Z, Szepes A, Pap A, Földesi I, Terzin V, Tiszlavicz L, Wittmann T. Autoimmune pancreatitis in Hungary: a multicenter nationwide study. Pancreatology 2011; 11:261-267.

55. Yamamoto M, Harada S, Ohara M, Suzuki C, Naishiro Y, Yamamoto H, Takahashi H, Imai K. Clinical and pathological differences between Mikulicz's disease and Sjögren's syndrome. Rheumatology (Oxford) 2005; 44:227-234.

56. Fiebiger E, Hammerschmid F, Stingl G, Maurer D. Anti-FcepsilonRIalpha autoantibodies in autoimmune-mediated disorders. Identification of a structure-function relationship. $J$ Clin Invest 1998; 101:243-251.

57. Skinnider BF, Elia AJ, Gascoyne RD, Trümper LH, von Bonin F, Kapp U, Patterson B, Snow BE, Mak TW. Interleukin 13 and interleukin 13 receptor are frequently expressed by Hodgkin and Reed-Sternberg cells of Hodgkin lymphoma. Blood 2001; 97:250-255.

58. Döpp R, Schmidt E, Chimanovitch I, Leverkus M, Bröcker EB, Zillikens D. IgG4 and IgE are the major immunoglobulins targeting the NC16A domain of BP180 in Bullous pemphigoid: serum levels of these immunoglobulins reflect disease activity. J Am Acad Dermatol 2000; 42:577-583.

59. Kawassaki AM, Haga H, Dantas TC, Musolino RS, Baldi BG, Carvalho CR, Kairalla RA, Mauad T. Adenopathy and pulmonary infiltrates in a Japanese emigrant in Brazil. Chest 2011; 139:947-952.

60. Fukuma N, McLachlan SM, Petersen VB, Kau P, Bradbury J, Devey M, Bleasdale K, Grabowski P, Smith BR. Human thyroglobulin autoantibodies of subclasses IgG2 and IgG4 bind to different epitopes on thyroglobulin. Immunology 1989; 67:129-131.

61. Sprangers B, Claes K. IgG4-related disease should be considered in cases of hypocomplementemic immune-complex tubulointerstitial nephritis. Letters and Replies NDT Plus 2010; 3:326-334.

62. Masaki Y, Sugai S, Umehara H. IgG4-related diseases including Mikulicz's disease and sclerosing pancreatitis: diagnostic insights. J Rheumatol 2010; 37:1380-1385. 
63. Suzuki S, Kida S, Ohira Y, Ohba T, Miyata M, Nishimaki T, Morito T, Kasukawa R, Hojyo H, Wakasa H. [A case of Sjögren's syndrome accompanied by lymphadenopathy and IgG4 hypergammaglobulinemia]. Ryumachi 1993; 33:249-254.

64. Choudhuri G, Lakshmi CP, Goel A. Pancreatic diabetes. Trop Gastroenterol 2009; 30:7175.

65. Cui Y, Andersen DK. Pancreatogenic diabetes: special considerations for management. Pancreatol 2011; 11:279-294.

66. Satoh J, Takahashi K, Takizawa Y, Ishihara H, Hirai M, Katagiri H, Hinokio Y, Suzuki S, Tsuji I, Oka Y. Secondary sulfonylurea failure: comparison of period until insulin treatment between diabetic patients treated with gliclazide and glibenclamide. Diabetes Res Clin Pract 2005; 70:291-297.

67. Cavallini G, Vaona B, Bovo P, Cigolini M, Rigo L, Rossi F. Diabetes in chronic alcoholic pancreatitis. Role of residual beta cell function and insulin resistance. Dig Dis Sci 1993; 38:497-501.

68. Sjoberg RJ, Kidd GS. Pancreatic diabetes mellitus. Diabetes Care 1989; 12:715-724.

69. Miura J, Yokoyama J, Miura A, Mori Y, Ito K, Ikeda Y. Clinical efficacy of multiple insulin injection regimen in pancreatogenic diabetes (in Japanese). J Jpn Diabet Soc 1991; 34:685-691.

70. Gerő L. A pancreatogen diabetes okai, tünettana és kezelése. Diabetologia Hungarica 2002; 10(Suppl. 3):19-22.

71. Kawabe K, Ito T, Igarashi H, Takayanagi R. The current managements of pancreatic diabetes in Japan. Clin J Gastroenterol 2009; 2:1-8.

72. Starke AAR, Cupers HJ, Berger M. Therapeutic problems in diabetes secondary to pancreopathy. In: Tiengo A, Alberti KGMM, Del Prato S, Vranic M, editors. Diabetes secondary to pancreopathy. Amsterdam: Excerpta Medica; 1988. p. 227-233. 
9. ANNEXES 
Annex I. 


\title{
Autoimmune Pancreatitis in Hungary: A Multicenter Nationwide Study
}

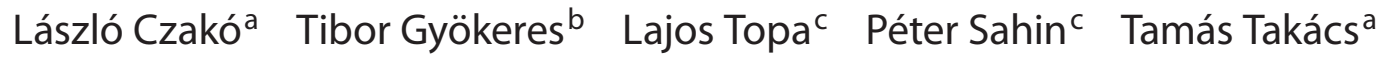 \\ Áron Vincze ${ }^{f}$ Zsolt Dubravcsik $^{\mathrm{e}}$ Attila Szepes $^{\mathrm{e}}$ Ákos Pap $^{\mathrm{d}}$ Imre Földesi $^{\mathrm{a}}$ \\ Viktória Terzin $^{\mathrm{a}}$ László Tiszlavicz $^{\mathrm{g}}$ Tibor Wittmann $^{\mathrm{a}}$

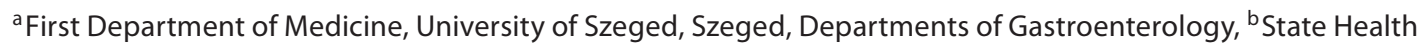 \\ Center and 'Szent-Imre Hospital, and d Department of Gastroenterology and Endoscopy, National Cancer Institute, \\ Budapest, ${ }^{e}$ Department of Gastroenterology, Bács-Kiskun County Hospital, Kecskemét, ${ }^{\mathrm{f}}$ First Department of \\ Medicine, University of Pécs, Pécs, and ${ }^{9}$ Department of Pathology, University of Szeged, Szeged, Hungary
}

\author{
Key Words \\ Autoimmune pancreatitis - Granulocytic epithelial \\ lesion • Idiopathic duct centric pancreatitis • IgG4 • \\ Lymphoplasmacytic sclerosing pancreatitis $\cdot$ Steroid \\ therapy
}

\begin{abstract}
Background: To date, most cases of autoimmune pancreatitis (AIP) have been reported from Japan. The aim of the present study was to assess the clinical features and management of AIP cases in Hungary. Methods: The demographics, clinical presentation, laboratory and imaging findings, extrapancreatic involvement, treatment response and recurrence were evaluated in the first 17 patients diagnosed with AIP in Hungary. Results: The mean age at presentation was 42.7 years (range: $16-74) ; 47 \%$ of the patients were women. Newonset mild abdominal pain (76\%), weight loss (41\%) and jaundice $(41 \%)$ were the most common symptoms, with inflammatory bowel disease being the most frequent (36\%) extrapancreatic manifestation. Diffuse pancreatic swelling was seen in 7 patients (41\%) and a focal pancreatic mass in 8 (47\%). Endoscopic retrograde cholangiopancreatography revealed pancreatic duct strictures in all study patients. The
\end{abstract}

serum IgG4 level at presentation was elevated in $62 \%$ of the 8 patients in whom it was measured. All the percutaneous core biopsies ( 5 patients) and surgical specimens ( 2 patients), and 2 of the 4 biopsies of the papilla of Vater revealed the typical characteristic findings of AIP: a diffuse lymphoplasmacytic infiltration, marked interstitial fibrosis and obliterative phlebitis. Immunostaining indicated IgG4-positive plasma cells in $62 \%$ of the 8 patients in whom it was performed. Granulocytic epithelial lesions (GEL) were present in 3 patients. The patients without GELs were older (mean age 59 years), while those with GEL were younger (mean age 34 years), and 2 of 3 were female and had ulcerative colitis. A complete response to steroid treatment was achieved in all 15 patients. Because of the suspicion of a pancreatic tumor, 2 patients with focal AIP underwent partial pancreatectomy. One patient relapsed, but responded to azathioprine. Conclusions: This first Hungarian series has confirmed several previously reported findings on AIP. AIP with GEL was relatively frequent among our patients: these patients tended to be younger than in earlier studies and displayed a female preponderance with a high coincidence of ulcerative colitis. Performance of a percutaneous biopsy is strongly recommended. The response to immunosuppressive therapy was excellent.

\section{KARGER \\ Fax +4161306 1234 \\ E-Mail karger@karger.ch}

www.karger.com
(C) 2011 S. Karger AG, Basel and IAP

$1424-3903 / 11 / 0112-0261 \$ 38.00 / 0$

Accessible online at:

www.karger.com/pan
László Czakó, MD, PhD

First Department of Medicine

University of Szeged, PO Box 427

HU-6701 Szeged (Hungary)

Tel. +36 62545 187, E-Mail czal@in1st.szote.u-szeged.hu 


\section{Introduction}

Autoimmune pancreatitis (AIP) is a special type of chronic pancreatitis (CP), which displays clinical, serological, radiological and in particular histological features that are clearly distinct from other types of $\mathrm{CP}$, such as alcoholic, hereditary and paraduodenal CP. The characteristics of the disease have been described in detail in excellent reviews [1-5]. Most cases of AIP have been reported from Japan. Although AIP is currently more often recognized in Europe [6-10], the number of European clinical reports to date is low and no study is available from central Eastern Europe.

AIP predominantly affects males over the age of 50 years. Recent studies demonstrated that two distinct histological patterns of AIP exist [9-11]. The histological pattern in type-1 AIP, referred to as lymphoplasmacytic sclerosing pancreatitis (LPSP), is characterized by a periductal lymphoplasmacytic infiltration, storiform fibrosis, obliterative phlebitis and IgG4-positive plasma cells. LPSP corresponds to the Japanese description of AIP [12] and is thought to be the pancreatic manifestation of an IgG4-associated systemic disease [13]. IgG4-related systemic diseases may involve the biliary tree, salivary glands, retroperitoneum, stomach, lymph nodes and kidneys. An extrapancreatic manifestation is seen in about $40-50 \%$ of the cases. The histopathological pattern in type-2 AIP is known as idiopathic duct centric CP (IDCP) or granulocyte epithelial lesion (GEL)-positive pancreatitis, which resembles the European description of ductdestructive CP $[9,14]$.

The aim of the present prospective multicenter study was to assess the clinical features, laboratory and imaging findings, extrapancreatic involvement, treatment response and recurrence of AIP cases in Hungary.

\section{Patients and Methods}

Between May 1, 2008, and October 30, 2010, patients diagnosed with AIP in Hungarian Gastroenterological Centers were enrolled in our study. The diagnosis of type-1 AIP was established according to the HISORt criteria [15], while type-2 AIP was distinguished on the basis of the presence of the histological criterion GEL $[9,11]$. Patient data were retrieved from medical documentation and follow-up data and were collected prospectively. All the patients participated in the continuous clinical follow-up. Treatment was carried out in the course of everyday clinical practice. All the patients underwent abdominal CT. In the event of obstructive jaundice, therapeutic endoscopic retrograde cholangiopancreatography (ERCP) was performed, and a polyethylene stent was inserted into the bile duct if optimization of bile flow
Table 1. Clinical presentation of the AIP patients

\begin{tabular}{lc}
\hline Age, years & $42.7(16-74)$ \\
Female, $\mathrm{n}$ & $8(47 \%)$ \\
Abdominal pain, $\mathrm{n}$ & $13(76 \%)$ \\
Weight loss, $\mathrm{n}$ & $7(41 \%)$ \\
Obstructive jaundice, $\mathrm{n}$ & $7(41 \%)$ \\
Diabetes mellitus, $\mathrm{n}$ & $2(12 \%)$ \\
Autoimmune disorder, $\mathrm{n}$ & $8(47 \%)$ \\
\hline
\end{tabular}

was necessary. Depending on the local possibilities, magnetic resonance cholangiopancreatography and/or diagnostic ERCP were performed to visualize abnormalities in the biliopancreatic region. When focal enlargement of the pancreas was detected, ultrasound-guided fine-needle aspiration or core biopsy was carried out. If the papilla of Vater was swollen, the biopsy was taken by means of duodenoscopy. The diagnosis of type-1 AIP was supported by the presence of duct centric lymphoplasmacytic infiltration, storiform fibrosis, obliterative phlebitis and >10 IgG4positive plasma cells per high power field. IgG4 immunohistochemical staining was performed with monoclonal anti-human IgG4 antibody (Invitrogen, Carlsbad, Calif., USA). IgG4 seronegativity and the presence of GEL were diagnostic of type-2 AIP. The level of serum IgG4 was measured in the available samples (Binding Site Ltd., Birmingham, UK).

After the diagnosis of AIP had been established, the patients were treated with 30-40 mg prednisolone per day for 1-2 months. After 4 weeks, response was assessed. Response to therapy was defined as complete when a symptomatic improvement and complete resolution of the imaging abnormalities were seen. In the event of an adequate therapeutic response, the steroid dose was tapered to $5 \mathrm{mg} /$ week. If a relapse occurred during the decrease in the steroid dose, the level of prednisolone was increased during the acute flare-up, and azathioprine at a dose of $1-2 \mathrm{mg} / \mathrm{kg}$ body weight per day was added for long-term immunosuppression. In patients who had undergone stent implantation in the bile duct, ERCP examination was repeated after steroid therapy; in case of improvement of the stenosis, the stent was removed.

Data were statistically evaluated using the $\chi^{2}$ test. Values of $\mathrm{p}<0.05$ were accepted as statistically significant.

\section{Results}

AIP was diagnosed in 17 patients during the study period. At the time of establishment of the diagnosis, the median age of the patients was 42.7 years (range: 16-74); $47 \%$ of them were women (table 1). The most frequent symptoms were mild abdominal pain, a moderate weight loss and obstructive jaundice. In 5 patients (29\%), inflammatory bowel disease had been diagnosed earlier, 2 patients had type-1 diabetes mellitus and another patient had sialadenitis. The serum levels of pancreatic enzymes 


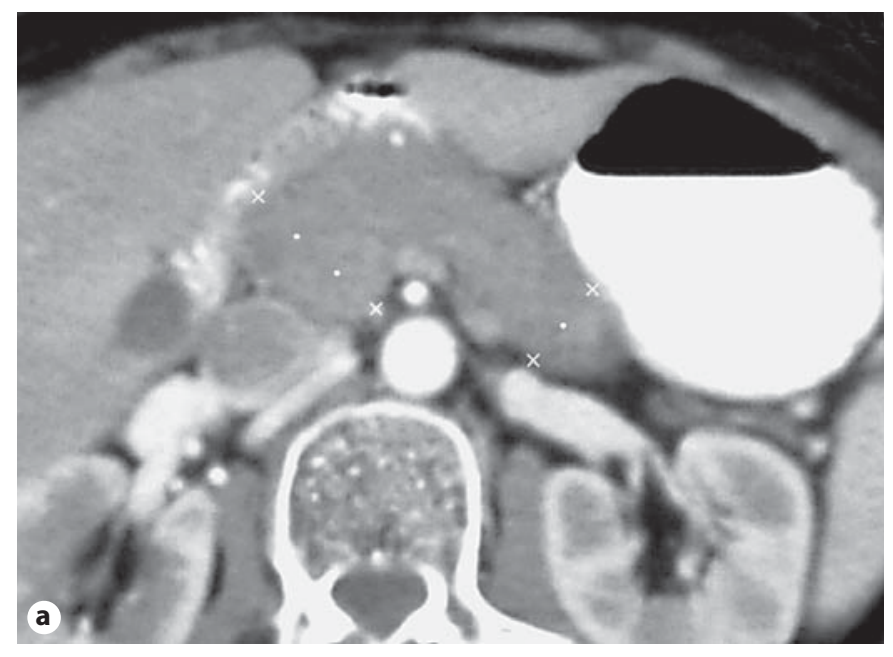

Fig. 1. CT scan demonstrates diffuse enlargement of the pancreas in a 62-year-old female patient (a). Following a 4-week steroid treatment $(32 \mathrm{mg})$, she is symptom free, and the pancreas volume becomes normal (b). CT reveals focal enlargement (arrow) of the pancreas in a 72-year-old male (c).

and Ca $19-9$ were mildly elevated in $40 \%$ of the 15 and $17 \%$ of the 6 patients, respectively, in whom it was evaluated. The serum IgG4 level at presentation was elevated in $62 \%$ of the 8 patients in whom it was assessed. Serum levels of antinuclear antibody were increased in $50 \%$ of the patients in whom it was measured. Imaging examinations revealed a diffuse, sausage-like widening of the pancreas in 7 patients (41\%) and focal enlargement of the pancreas in 8 patients (47\%; fig. 1a, c), while in 2 patients (12\%) the pancreas did not exhibit any enlargement. In $66 \%$ of the patients with type- 2 AIP, there was a focal mass in the pancreas. ERCP revealed stenosis of Wirsung's duct with a wall irregularity in all study patients; in 4 patients (33\%), the stenosis was diffuse, and in 8 patients (67\%) it was segmental (fig. 2a, b). Seven patients (41\%) had obstructive jaundice; ERCP revealed stenosis of the intrapancreatic portion of the common bile duct (fig. $2 \mathrm{~b}$ ) in all of them; a stent was implanted in 3 patients to ensure bile flow. These stents were removed after resolution of the strictures following steroid therapy.
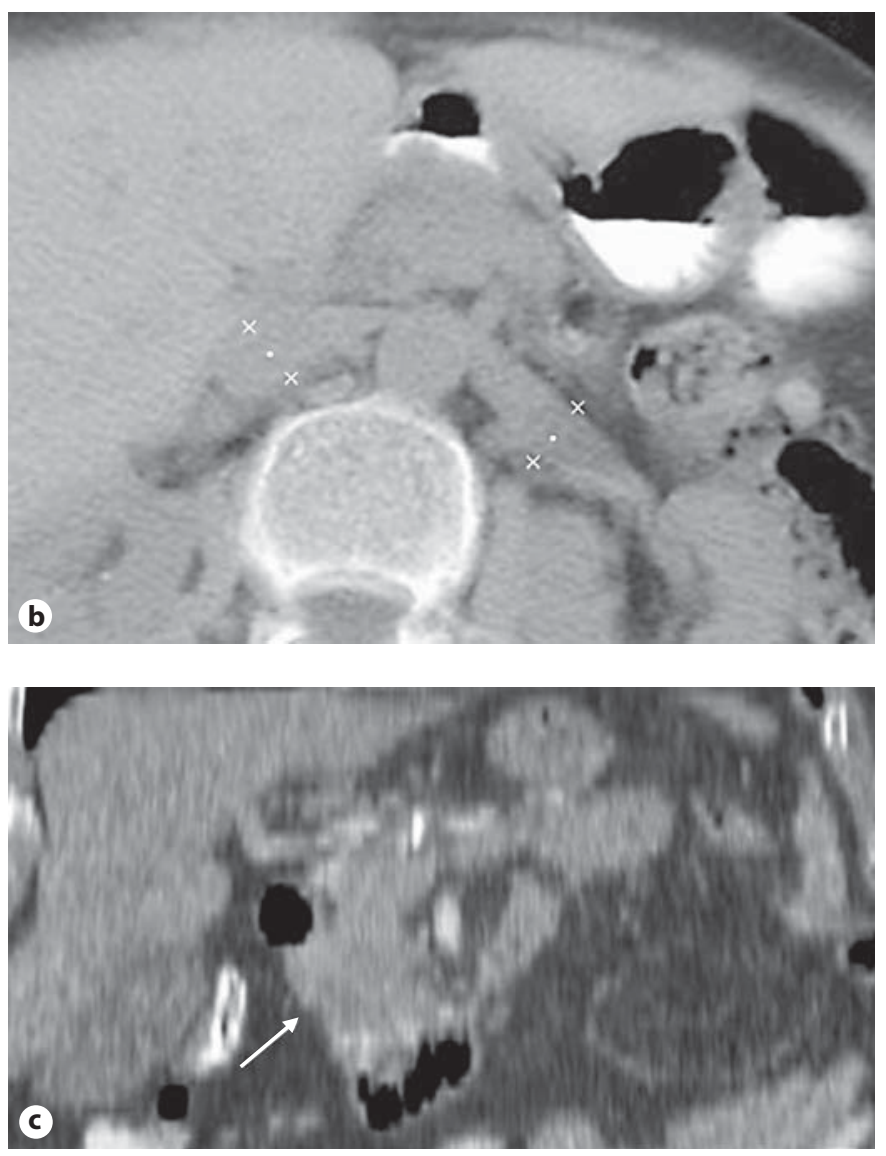

For histological examination, sampling was performed with different means. In 1 case the sample obtained by ultrasound-guided fine-needle aspiration was not appropriate for establishment of the diagnosis of AIP; however, cytological examination did not reveal tumor cells either. All 5 cases receiving percutaneous ultrasound-guided core biopsy demonstrated a periductal lymphoplasmacytic infiltration with whirling fibrosis and phlebitis (fig. 3).

Malignancy could not be excluded in 2 AIP cases because of the presence of a pancreatic mass (both involved type-2 AIP), and pancreatic head resection was performed. Histological examination of the resected specimen supported the diagnosis of AIP. In 4 cases, biopsy samples were taken from the swollen papilla of Vater during duodenoscopy; 2 of them were diagnostic of AIP; in both cases, only the pancreatic head was affected. IgG4 immunohistochemical examinations could be performed in 8 patients, of whom 5 (63\%) were positive (fig. $4 a$ ). However, in the serologically negative cases granulocytic 

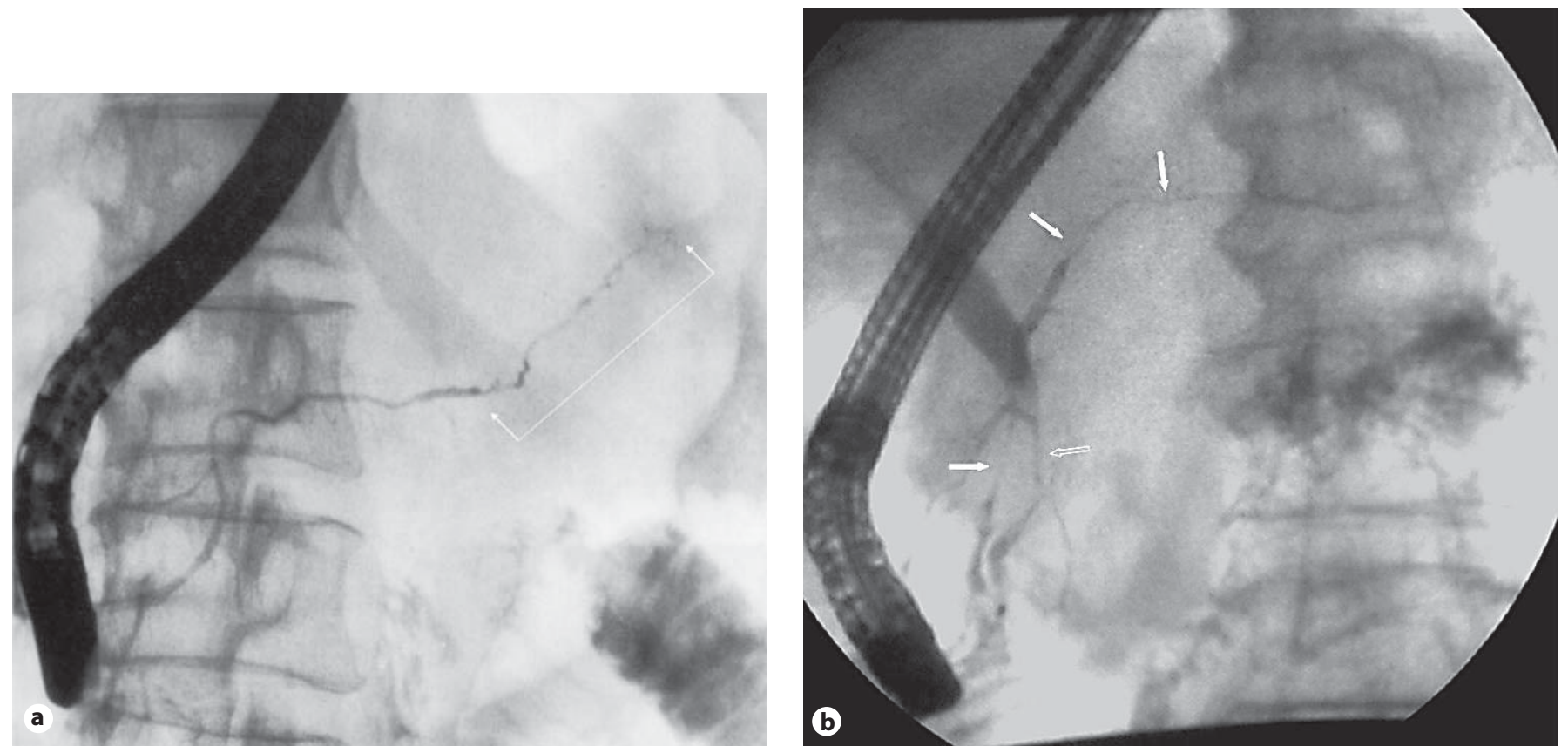

Fig. 2. ERCP reveals diffuse irregular stenosis of the pancreatic duct (a) and multiple segmental stenosis of the pancreatic duct without upstream dilation (arrows) as well as a stricture of the intrapancreatic portion of the common bile duct (open arrow; b).

Table 2. Demographics of the patients with LPSP and IDCP

\begin{tabular}{lll}
\hline & LPSP & IDCP \\
\hline Age, years & $59(37-74)$ & $34(19-56)$ \\
Females, $\mathrm{n}$ & $3(60 \%)$ & $2(66 \%)$ \\
Ulcerative colitis, $\mathrm{n}$ & $1(20 \%)$ & $2(66 \%)$ \\
\hline
\end{tabular}

infiltration of the ductal epithelial cells (GEL) was revealed besides the classical lymphoplasmacytic infiltration, i.e. IDCP was identified (fig. 4b).

Concerning the demographics of the patients with the two histological types of AIP, a majority of the LPSP patients were older, while the IDCP patients were significantly younger. There was no male predominance in our IDCP patients, and an association with ulcerative colitis was common (table 2).

A complete response was achieved in all 15 patients during steroid therapy. The patients became asymptomatic within a short time, the elevated liver function decreased, and the enlargement of the pancreas and the narrowing of the bile duct had reversed by 4 weeks after starting the steroid therapy (fig. 1b). A relapse occurred in 1 patient (7\%) during the dose reduction in prednisolone, but remission was again achieved following a dose increase in steroid treatment and the administration of azathioprine as long-term immunosuppression.

\section{Discussion}

To date, a majority of the AIP cases have been reported from Japan, and even the existence of the disease was debated in the West until comparatively recently $[16,17]$. Our study tends to confirm recent data [6-10] indicating that AIP is not restricted to some specific region of the world, but also occurs in central Eastern Europe. The epidemiology of our AIP series differs from those previously reported. A nationwide study indicated that the peak age at onset was 61-65 years, and those older than 46 years accounted for $96 \%$ of the overall number of patients [18]. AIP predominantly affects men in Japan, with a male:female ratio of 2.85:1 [17]. In contrast to the Japanese data, the patients in our series were appreciably younger, with a median age at presentation of 42.7 years, and the male:female ratio was 1.13:1. Our patients were 

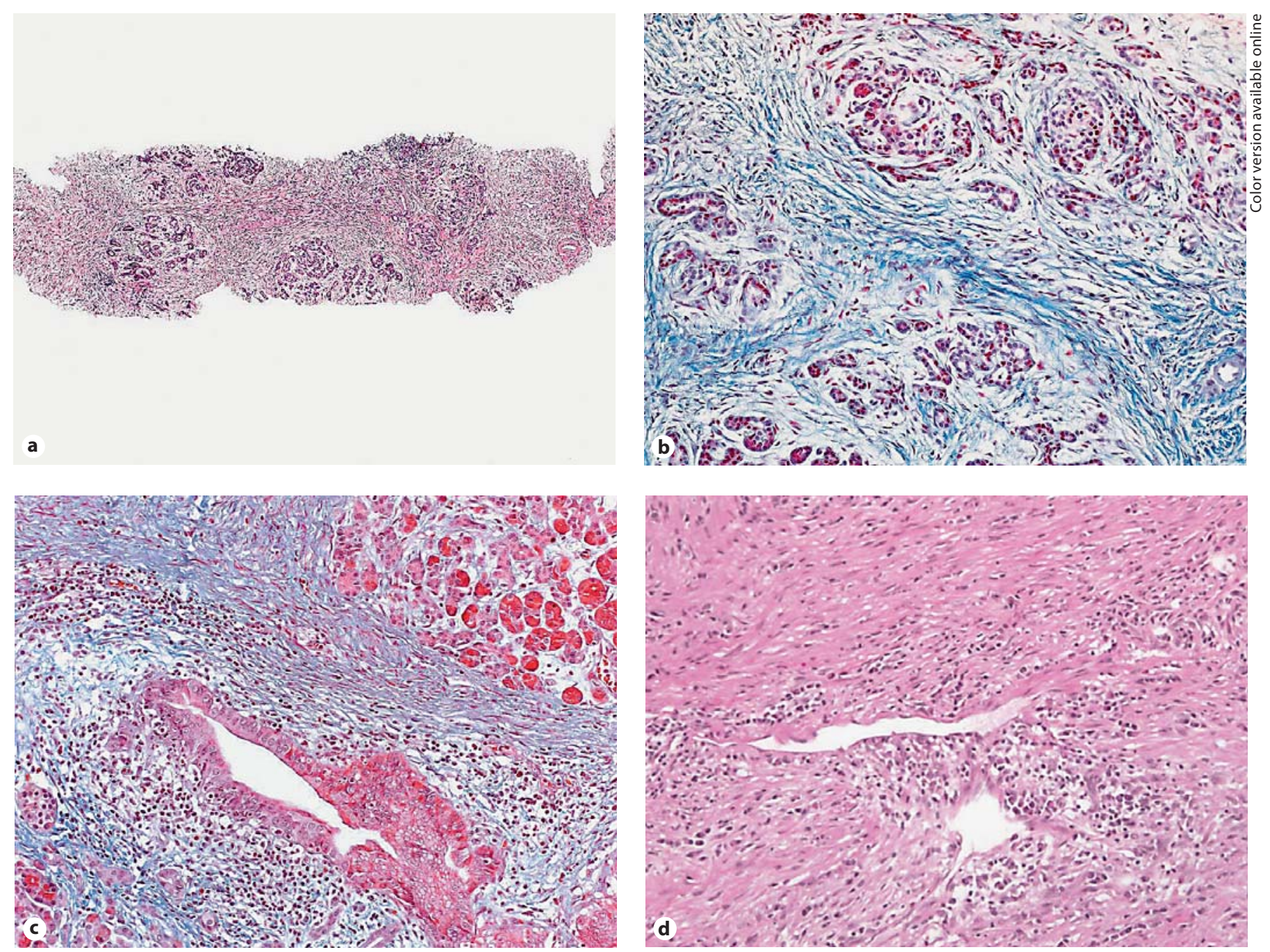

Fig. 3. Histological examination demonstrates storiform fibrosis around the atrophic lobules with a dense mononuclear cell infiltration (HE; a), fibrosis rich in collagen fibers (trichrome dye; b), periductal lymphoplasmacytic infiltration (HE; c) and venulitis (HE; d).

even younger than the AIP patients reported in recent UK, European and US series, where the median age at presentation was 53,56 and 62.5 years, respectively [7, 9, 19]. Moreover, there was a male preponderance $(100,66$ and $65 \%$ were male in the UK, European and US studies, respectively), in agreement with the reports from East Asia. In support of our study, a lower median age (43.4 years) at presentation was also reported in an Italian study [6], although they noted a male predominance (62\%).

The results of recent European and American studies have led to AIP being subclassified into types 1 and 2 [9-11]. Type 1, LPSP, the disease classically described in
Japan, primarily affects elderly males $[3,5,18]$. Type 2 , AIP, which frequently occurs in Europe, is seen in younger patients and does not display a gender predilection [9, 10]. There have been only 2 studies where the incidence of type-2 AIP was reported: $37.5 \%$ in a European study [10] and $27.5 \%$ in a US study [20]. In our series, $37.5 \%$ of the AIP cases with available results of pancreas histology proved to be type- 2 AIP and a further 3 patients had 'probable' type- 2 AIP based on the imaging data, the normal serum IgG4 level and the response to steroids. The somewhat higher incidence of type-2 AIP in our series may explain the younger age and the female predominance among our AIP patients. Nevertheless, a male pre- 

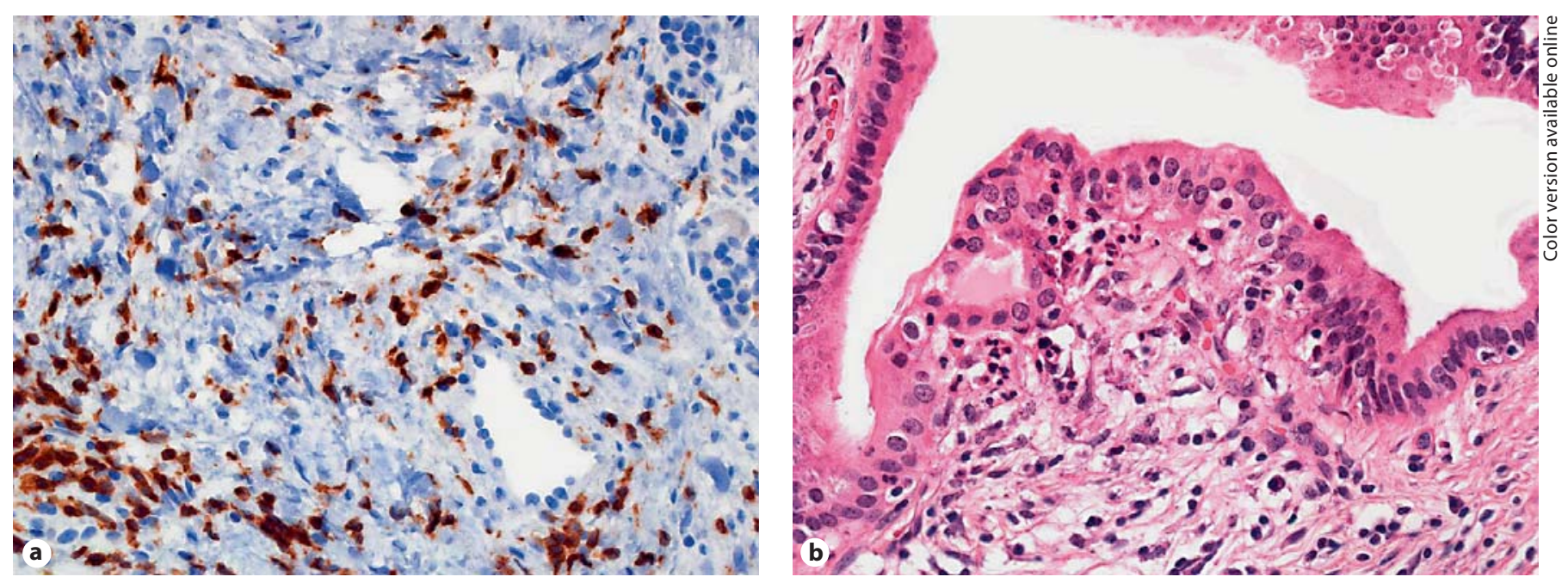

Fig. 4. Histological findings in AIP. a Type 1: periductal accumulation of IgG4-positive plasma cells (HE). b Type 2: duct with GEL (HE).

ponderance was not observed among our type-1 AIP patients either.

An association of AIP with other autoimmune diseases was reported in $35-56 \%$ of the Japanese cases $[3,5,18]$, which is in accord with our Hungarian series (47\%). However, in our series, the nature of the autoimmune diseases differed from that reported in previous studies $[3,5,7,19]$. Inflammatory bowel disease was the most frequent (5 of 8) associated autoimmune disease, confirming the Italian study [6]. This can be explained by the pronounced occurrence of type-2 AIP in our series.

It was earlier demonstrated that the serum IgG4 level is a highly sensitive (95\%) and specific (97\%) indicator in the diagnosis of AIP [21]. We observed elevated serum IgG4 levels in only $62 \%$ of our patients, a finding in agreement with a report from the US, where the serum IgG4 level was elevated in $71 \%$ of the patients [15]. This emphasizes that the detection of a normal IgG4 level does not exclude the presence of AIP. About $20 \%$ of AIP patients do not have elevated serum IgG4 levels. These cases may include IDCP, LPSP with low activity, or sclerosing pancreatitis other than LPSP or IDCP [22].

Certain histological features in the pancreas are diagnostic of AIP $[1,15]$. Eight of our patients exhibited a discrete mass in the pancreas. Ultrasound-guided pancreatic core needle biopsies in 5 of these patients were all diagnostic, demonstrating a lymphoplasmacytic infiltration of the pancreas. One ultrasound-guided pancreatic fine-needle aspiration was not diagnostic. Four patients had biopsies of the swollen papilla and in 2 of them a lym- phoplasmacytic infiltration was noted histologically. The major duodenal papilla is a conduit between the duodenum and the pancreatobiliary system, and its pathological examination may reflect underlying pancreatobiliary disorders. Previous studies have demonstrated a $55-80 \%$ sensitivity of positive IgG4 immunostaining of the major papilla [23]. Our finding was similar to this result. AIP was manifested as a focal enlargement of the pancreatic head in the 2 patients with positive IgG4 immunostaining of the major papilla. Furthermore, the postoperative histological examination of the resected pancreatic head mass in another focal AIP patient revealed the typical lymphoplasmacytic infiltration of the papilla of Vater, although IgG4 immunostaining was negative. The other 2 patients with negative IgG4 immunostaining of the major papilla had the diffuse form of AIP, and 1 of them had probable IDCP.

The response to steroid therapy is a HISORt criterion in the diagnosis of AIP. In agreement with previous reports $[1,3,6,7,19]$, rapid symptomatic response and improvements in liver biochemistry and morphology were observed 4 weeks after the start of steroid therapy. However, in contrast to the earlier reports, recurrence was rarely encountered. In our series, only 1 patient had a recurrence. The long-term follow-up will disclose the final number of patients who relapse.

In conclusion, AIP is present in the Hungarian population. Various previously reported findings on the clinical presentation and management of AIP were confirmed in our series. AIP with GEL was relatively frequent among 
our patients; these patients were younger, and presented a female preponderance and a high coincidence of ulcerative colitis. Performance of a percutaneous biopsy is strongly recommended. The response to steroid therapy was excellent. Further work is required to determine the distribution and characteristics of type-2 AIP more accurately.

\section{Acknowledgment}

This work was partly supported by TÁMOP-4.2.1.B-09/1/ KONV 3 and OTKA No. K78311.

\section{References}

1 Detlefsen S, Drewes AM: Autoimmune pancreatitis. Scand J Gastroenterol 2009;44: 1391-1407.

2 Czakó L: Autoimmune pancreatitis: Aluldiagnosztizált kórkép? Lege Artis Med 2006; 6:505-510.

3 Shimosegawa T, Kanno A: Autoimmune pancreatitis in Japan: overview and perspective. J Gastroenterol 2009;44:503-517.

4 Park DH, Kim MH, Chari ST: Recent advances in autoimmune pancreatitis. Gut 2009;12:1680-1689.

5 Okazaki K, Kawa S, Kamisawa T, Ito T, Inui $\mathrm{K}$, Irie $\mathrm{H}$, et al: Japanese clinical guidelines for autoimmune pancreatitis. Pancreas 2009:8:849-866.

6 Frulloni L, Scattolini C, Falconi M, Zamboni G, Capelli P, Manfredi R, et al: Autoimmune pancreatitis: differences between the focal and diffuse forms in 87 patients. Am J Gastroenterol 2009;9:2288-2294

7 Church NI, Pereira SP, Deheragoda MG, Sandanayake N, Amin Z, Lees WR, et al: Autoimmune pancreatitis: clinical and radiological features and objective response to steroid therapy in a UK series. Am J Gastroenterol 2007;11:2417-2425.

8 Löhr JM, Faissner R, Koczan D, Bewerunge P, Bassi C, Brors B, Eils R, Frulloni L, Funk A, Halangk W, Jesnowski R, Kaderali L, Kleeff J, Krüger B, Lerch MM, Lösel R, Magnani M, Neumaier M, Nittka S, SahinTóth M, Sänger J, Serafini S, Schnölzer M Thierse HJ, Wandschneider S, Zamboni G, Klöppel G: Autoantibodies against the exocrine pancreas in autoimmune pancreatitis: gene and protein expression profiling and immunoassays identify pancreatic enzymes as a major target of the inflammatory process. Am J Gastroenterol 2010;105:20602071.
9 Zamboni G, Lüttges J, Capelli P, Frulloni L, Cavallini G, Pederzoli P, et al: Histopathological features of diagnostic and clinical relevance in autoimmune pancreatitis: a study on 53 resection specimens and 9 biopsy specimens. Virchows Arch 2004;445:552-563.

10 Klöppel G, Detlefsen S, Chari ST, Longnecker DS, Zamboni G: Autoimmune pancreatitis: the clinicopathological characteristics of the subtype with granulocytic epithelial lesions. J Gastroenterol 2010;45:787-793.

11 Notohara K, Burgart LJ, Yadav D, Chari S, Smyrk TC: Idiopathic chronic pancreatitis with periductal lymphoplasmacytic infiltration: clinicopathologic features of 35 cases. Am J Surg Pathol 2003;27:1119-1127.

12 Yoshida K, Toki F, Takeuchi T, Watanabe S, Shiratori K, Hayashi N: Chronic pancreatitis caused by an autoimmune abnormality. Proposal of the concept of autoimmune pancreatitis. Dig Dis Sci 1995;40:1561-1568.

13 Kamisawa T, Okamoto A: Autoimmune pancreatitis: proposal of IgG4-related sclerosing disease. J Gastroenterol 2006;41:613625.

14 Ectors N, Maillet B, Aerts R, Geboes K, Donner A, Borchard F, Lankisch P, Stolte M, Lüttges J, Kremer B, Klöppel G: Non-alcoholic duct destructive chronic pancreatitis. Gut 1997;41:263-268.

15 Chari ST, Smyrk TC, Levy MJ, Topazian MD, Takahashi N, Zhang L, Clain JE, Pearson RK, Petersen BT, Vege SS, Farnell MB: Diagnosis of autoimmune pancreatitis: the Mayo Clinic experience. Clin Gastroenterol Hepatol 2006;4:1010-1016.
16 Pearson RK, Longnecker DS, Chari ST, Smyrk TC, Okazaki K, Frulloni L, et al: Controversies in clinical pancreatology. Autoimmune pancreatitis: does it exist? Pancreas 2003;27:1-13

17 Varadarajulu S, Cotton PB: Autoimmune pancreatitis: is it relevant in the west? Gastroenterology 2003; $125: 1557$

18 Nishimori I, Tamakoshi A, Otsuki M: Prevalence of autoimmune pancreatitis in Japan from a nationwide survey in 2002. J Gastroenterol 2007;42(suppl XVIII):6-8.

19 Raina A, Yadav D, Krasinskas AM, McGrath KM, Khalid A, Sanders M, Whitcomb DC Slivka A: Evaluation and management of autoimmune pancreatitis: experience at a large US center. Am J Gastroenterol 2009;104: 2295-2306.

20 Sah RP, Chari ST, Pannala R, Sugumar A, Clain JE, Levy MJ, Pearson RK, Smyrk TC, Petersen BT, Topazian MD, Takahashi N, Farnell MB, Vege SS: Differences in clinical profile and relapse rate of type 1 versus type 2 autoimmune pancreatitis. Gastroenterology 2010;139:140-148.

21 Hamano H, Kawa S, Horiuchi A, Unno $\mathrm{H}$, Furuya N, Akamatsu T, Fukushima M, Nikaido T, Nakayama K, Usuda N, Kiyosawa K: High serum IgG4 concentrations in patients with sclerosing pancreatitis. N Engl J Med 2001;344:732-738.

22 Kamisawa T, Takuma K, Tabata T, Inaba Y, Egawa N, Tsuruta K, Hishima T, Sasaki T, Itoi T: Serum IgG4-negative autoimmune pancreatitis. J Gastroenterol 2011;46:108116.

23 Kim MH, Moon SH, Kamisawa T: Major duodenal papilla in autoimmune pancreatitis. Dig Surg 2010;27:110-114. 
Annex II. 


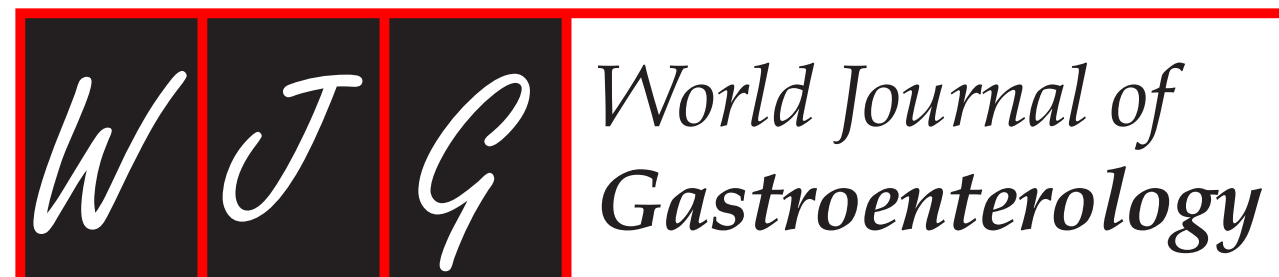

Online Submissions: http:/ / www.wjgnet.com/1007-9327office wjg@wjgnet.com

doi:10.3748/wjg.v18.i21.2649

World J Gastroenterol 2012 June 7; 18(21): 2649-2653 ISSN 1007-9327 (print) ISSN 2219-2840 (online) (C) 2012 Baishideng. All rights reserved.

\title{
Association between autoimmune pancreatitis and systemic autoimmune diseases
}

\author{
Viktória Terzin, Imre Földesi, László Kovács, Gyula Pokorny, Tibor Wittmann, László Czakó
}

\begin{abstract}
Viktória Terzin, Imre Földesi, Tibor Wittmann, László Czakó, First Department of Medicine, University of Szeged, H-6701 Szeged, Hungary

László Kovács, Gyula Pokorny, Department of Rheumatology, University of Szeged, H-6701 Szeged, Hungary

Author contributions: Czakó L and Terzin V made substantial contributions to study conception and design, contributed to the acquisition, analysis and interpretation of the data; Terzin $\mathrm{V}$ analyzed the data; Czakó L performed ultrasound examinations; Földesi I performed the IgG4 assay; Kovács L recruited the patients; Pokorny G, Wittmann T and Czakó L revised the article critically for important intellectual content; all authors approved the manuscript.

Supported by Grants TÁMOP-4.2.1./B-09/1/KONV and 4.2.208/1-2008-0002 (partly)

Correspondence to: László Czakó, MD, PhD, First Department of Medicine, University of Szeged, P.O. Box, 427, H-6701 Szeged, Hungary. czako.laszlo@med.u-szeged.hu

Telephone: +36-62-545187 Fax: +36-62-545185

Received: September 5, 2011 Revised: January 5, 2012

Accepted: April 10, 2012

Published online: June 7, 2012
\end{abstract}

\begin{abstract}
AIM: To investigate the association between autoimmune pancreatitis (AIP) and systemic autoimmune diseases (SAIDs) by measurement of serum immunoglobulin G4 (IgG4).
\end{abstract}

METHODS: The serum level of IgG4 was measured in 61 patients with SAIDs of different types who had not yet participated in glucocorticosteroid treatment. Patients with an elevated IgG4 level were examined by abdominal ultrasonography (US) and, in some cases, by computer tomography (CT).

RESULTS: Elevated serum IgG4 levels (919 $\pm 996 \mathrm{mg} /$ L) were detected in $17(28 \%)$ of the 61 SAID patients. 10 patients had Sjögren's syndrome (SS) (IgG4: $590 \pm$ $232 \mathrm{mg} / \mathrm{L}), 2$ of them in association with Hashimoto's thyroiditis, and 7 patients (IgG4: $1388 \pm 985.5 \mathrm{mg} / \mathrm{L}$ ) had systemic lupus erythematosus (SLE). The IgG4 level in the SLE patients and that in patients with SS were not significantly different from that in AIP patients (783 $\pm 522 \mathrm{mg} / \mathrm{L}$ ). Abdominal US and CT did not reveal any characteristic features of AIP among the SAID patients with an elevated IgG4 level.

CONCLUSION: The serum IgG4 level may be elevated in SAIDs without the presence of AIP. The determination of serum IgG4 does not seem to be suitable for the differentiation between IgG4-related diseases and SAIDs.

\section{(C) 2012 Baishideng. All rights reserved.}

Key words: Autoimmune pancreatitis; Serum immunoglobulin G4 level; Systemic lupus erythematosus; Sjögren's syndrome; Mikulicz's disease

Peer reviewer: Toshiyuki Ishiwata, Associate Professor, Department of Pathology, Integrative Oncological Pathology, Nippon Medical School, 1-1-5 Sendagi, Bunkyo-ku, Tokyo 113-8602, Japan

Terzin V, Földesi I, Kovács L, Pokorny G, Wittmann T, Czakó L. Association between autoimmune pancreatitis and systemic autoimmune diseases. World J Gastroenterol 2012; 18(21): 2649-2653 Available from: URL: http://www.wjgnet.com/1007-9327/full/ v18/i21/2649.htm DOI: http://dx.doi.org/10.3748/wjg.v18. i21.2649

\section{INTRODUCTION}

Autoimmune pancreatitis (AIP) is an increasingly recognized type of chronic pancreatitis that is clearly distinct from other types of chronic pancreatitis. It is characterized by its morphology, immunologic features, pathology and glucocorticosteroid responsiveness ${ }^{[1-4]}$. 
Immunological examinations in AIP patients have demonstrated high incidences of hypergammaglobulinemia (43\%), increased serum levels of immunoglobulin $\mathrm{G}(\mathrm{IgG})$ $(62 \%-80 \%)$ and $\operatorname{IgG} 4(68 \%-92 \%)$, and the presence of antinuclear antibodies (40\%-64\%) and rheumatoid factor (25\%). Among all the serological diagnostic features, an elevated serum level of IgG4 has the highest individual diagnostic value; however, it is not disease specific. Furthermore, an elevated serum IgG4 level correlates with the activity of $\mathrm{AIP}^{[5,6]}$. Kamisawa et al ${ }^{[7]}$ reported an association between serum IgG4 level and extrapancreatic lesions in patients with AIP. AIP patients with a serum IgG4 level $\geqslant 2200 \mathrm{mg} / \mathrm{L}$ frequently exhibit extrapancreatic lesions.

The immunologic and histologic features of AIP and the glucocorticosteroid responsiveness suggest an autoimmune mechanism for the development of the disease ${ }^{[8]}$. AIP is accompanied by other autoimmune diseases (sclerosing cholangitis, sclerosing sialadenitis, retroperitoneal fibrosis, enlarged celiac and hilar lymph nodes, chronic thyroiditis and interstitial nephritis, etc.) in 50\%-63\% of cases, suggesting that AIP may be a systemic disorder ${ }^{[1-4]}$. The occurrence of autoimmune diseases in association with AIP is well documented ${ }^{[9,10]}$, but the incidence of such associations has not been reported.

The aim of the present study was to assess the presence of AIP in different systemic autoimmune diseases (SAIDs) through measurement of the serum IgG4 level and examination of the morphology of the pancreas.

\section{MATERIALS AND METHODS}

\section{Patients and diagnosis of diseases}

Serum samples were obtained from 61 patients with different SAIDs who had been admitted to our Department of Rheumatology and had not participated in glucocorticosteroid treatment during the past 2 years. One male and 60 females (mean age 54.5 years, range $29-82$ years) were recruited.

Autoimmune diseases were diagnosed according to standard diagnostic criteria ${ }^{[11-14]}$. The diagnosis of AIP was based on the HISORt criteria ${ }^{[15]}$. The most frequent diagnosis was Sjögren's syndrome (SS), but systemic lupus erythematosus (SLE), Hashimoto thyroiditis, Raynaud's syndrome, polymyositis and systemic sclerosis also occurred (Table 1).

Serum samples were additionally obtained from 7 ageand sex-matched healthy subjects, and 6 patients with AIP. In one AIP patient, the AIP was accompanied by rheumatoid arthritis and ankylosing spondylitis.

All participants provided their written informed consent. The study protocol was approved by the ethics committee at the University of Szeged and was carried out in full accordance with the most recent revisions of the Helsinki Declaration.

\section{IgG4 assay}

After collection, serum samples were stored at $-70{ }^{\circ} \mathrm{C}$ until analyzed. The IgG4 subclass was determined by the ra-
Table 1 Distribution of gender and age in groups of patients

\begin{tabular}{lccr}
\hline & $\begin{array}{c}\text { No. of } \\
\text { patients }\end{array}$ & $\begin{array}{c}\text { Male/ } \\
\text { female }\end{array}$ & $\begin{array}{c}\text { Age } \\
\text { mean (range) }\end{array}$ \\
\hline Sjögren's syndrome & 35 & $1 / 34$ & $56.7(29-82)$ \\
Systemic lupus erythematosus & 22 & $0 / 22$ & $50.2(31-68)$ \\
Systemic sclerosis & 4 & $0 / 4$ & $59.5(45-80)$ \\
Normal subjects & 7 & $4 / 3$ & $68(56-80)$ \\
Autoimmune pancreatitis & 6 & $3 / 3$ & $53.7(27-75)$ \\
\hline
\end{tabular}

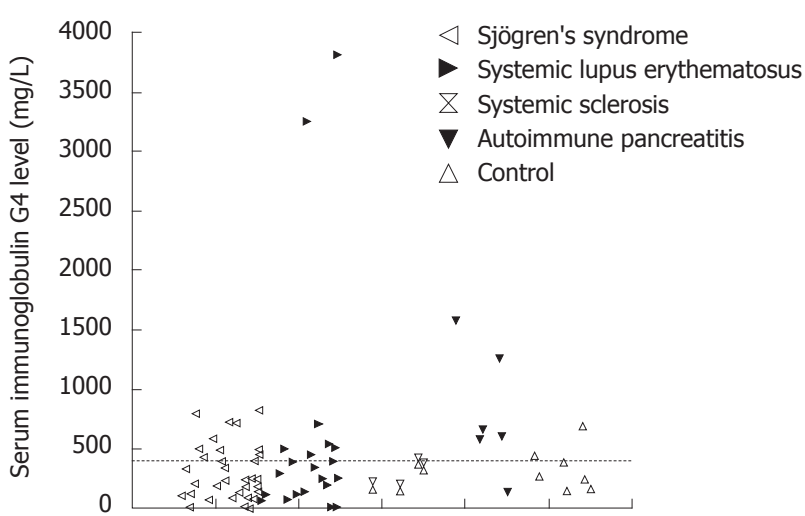

Figure 1 Serum immunoglobulin G4 levels in different systemic autoimmune diseases and autoimmune pancreatitis. Dotted line: Cutoff value ( $400 \mathrm{mg} / \mathrm{L})$.

dial immunodiffusion (RID) method (The Binding Site Limited, Birmingham, United Kingdom). The diameters of precipitation rings were measured after $72 \mathrm{~h}$. The results were read using the RID reference table. The lowest detection limit was $22.4 \mathrm{mg} / \mathrm{L}$. The intra- and interassay coefficients of variation were 3.26 and $0.89 \mathrm{CV} \%$, respectively, as stated by the manufacturer. A cutoff value of $400 \mathrm{mg} / \mathrm{L}$ was employed.

Patients with a serum IgG4 level of $>400 \mathrm{mg} / \mathrm{L}$ were examined by a gastroenterologist. The clinical and laboratory data were reviewed and abdominal ultrasonography (US) and computed tomography (CT) were performed.

\section{Anti-SS-A/SS-B autoantibody determination}

The presence of anti-SS-A/SS-B autoantibodies was determined by means of commercial enzyme-linked immunosorbent assays, conducted according to the protocols provided by the manufacturers.

Experimental data were evaluated statistically with the independent-samples $t$ test. $P$-values $<0.05$ were accepted as being statistically significant. Statistical data is expressed as mean $\pm \mathrm{SD}$.

\section{RESULTS}

An elevated serum IgG4 level (mean value $919 \pm 996$ $\mathrm{mg} / \mathrm{L})$ was detected in $17(28 \%)$ of the 61 SAID patients (Figure 1). Ten of the 17 patients had SS (mean serum IgG4 $590 \pm 232 \mathrm{mg} / \mathrm{L}$ ) (2 cases were associated with Hashimoto's thyroiditis), 7 (mean serum IgG4 $1388 \pm$ $985.5 \mathrm{mg} / \mathrm{L}$ ) were diagnosed with SLE. Two SLE patients showed markedly elevated IgG4 levels (> $3000 \mathrm{mg} / \mathrm{L}$ ). In 
one case, SLE was associated with Raynaud's syndrome, while the other patient suffered from xerophtalmia and bronchial asthma. The serum IgG4 level was elevated (mean serum IgG4 $783 \pm 522 \mathrm{mg} / \mathrm{L}$ ) in $5(83 \%$ ) of the 6 AIP patients. The patient with a normal level of IgG4 had typical pancreatic histology and his condition improved with steroid therapy. The IgG4 levels in these SLE and SS patients were not significantly different from that in the AIP patients.

US examination revealed a normal pancreas in 11 of the 17 SAID patients with elevated serum IgG4 levels, but raised the suspicion of AIP by demonstrating a gracile pancreas in 2 cases (both suffered from SS), and widening of the body or the tail of pancreas, each in a further one patient (both suffered from SLE). However, in none of these 4 cases was AIP confirmed by an abdominal CT scan. The US examinations indicated pancreatic steatosis in 2 additional cases. None of the SAID patients had pancreatic duct dilatation.

The presence of anti-SS-A/SS-B autoantibodies and the potential relation of this to an elevated $\mathrm{IgG} 4$ level were examined in the patients with SS. Both anti-SSA-positivity and anti-SS-B-positivity was detected in 22 patients; 7 of them exhibited an elevated IgG4 level. The anti-SS-A was positive and the anti-SS-B was negative in 9 cases; 2 of these patients had a high IgG4 level. In 4 patients with SS, neither anti-SS-A-positivity, nor antiSS-B-positivity was found; an elevated IgG4 level was detected in only one of these cases.

\section{DISCUSSION}

The present study has demonstrated that the serum IgG4 level may be elevated in SAIDs, without the presence of AIP.

AIP can be complicated by a variety of extrapancreatic lesions, which appear synchronously or metachronously with the pancreatic lesion, share the same pathological conditions, and show a favorable response to glucocorticosteroid therapy, characteristics indicative of a common pathophysiological background. Among the variety of extrapancreatic diseases, lachrymal and salivary gland lesions are some of the most frequent, found in $23 \%-39 \%$ of patients with AIP $^{[16,17]}$. Extrapancreatic lesions may mimic or be misdiagnosed as primary lesions of the corresponding organs, e.g., lachrymal and salivary gland lesions for SS. It is therefore necessary to differentiate between IgG4-related diseases and inherent diseases of the corresponding organ. When the pancreatic lesion is obscured, it may be difficult to detect these presumably IgG4-related extrapancreatic lesions ${ }^{[4]}$.

$\mathrm{IgG} 4$ is the rarest of the $4 \mathrm{IgG}$ subclasses in humans, with an incidence of about $4 \%$. IgG antibodies are predominantly involved in the secondary immune response; complement activation is possibly their most important biological function. The main role of $\mathrm{IgG} 4$ is presumably to protect against the biological effects of the complement-fixing IgG subclasses and to act in parasitic infestation or various forms of atopy ${ }^{[18-20]}$. Serum IgG4 levels are frequently and significantly elevated in AIP patients ${ }^{[6]}$ and an elevated level of serum IgG4 has been included among the laboratory criteria for the diagnosis of $\mathrm{AIP}^{[4,15]}$. AIP patients with 3 extrapancreatic lesions have been reported to have significantly higher IgG4 levels than those lacking such lesions ${ }^{[16]}$. The optimal cutoff value for discriminating AIP patients with extrapancreatic lesions from those without was demonstrated on the basis of receiver operator characteristic curves to be $2200 \mathrm{mg} / \mathrm{L}^{[7]}$.

The serum IgG4 level was measured in 61 SAID patients in our study, $28 \%$ of whom proved to have an elevated serum level of IgG4. However, none of them could be diagnosed with AIP according to the HISORt criteria. What could be the reason for this?

One explanation is the composition of our patient cohort. In Japan AIP predominantly affects men, with a male:female ratio of $2.85: 1^{[16]}$. Moreover, there was a male preponderance in the United Kingdom, European and US studies $(100 \%, 66 \%$ and 65\% male, respectively), similar to in reports from $\operatorname{Japan}^{[21-24]}$. In contrast, there was only one male in our patient population.

Lachrymal and salivary lesions associated with AIP were previously considered to be complications of SS. However, in contrast to those accompanying SS, the lachrymal and salivary gland lesions associated with AIP yield negative results for anti-SS-A/SS-B autoantibodies and show numerous IgG4-positive plasma cell infiltrations in the affected tissues. These lesions are currently thought to correspond to Mikulicz's disease ${ }^{[25]}$. The explanation for our negative results may be that there was only one patient with negative SS-A/SS-B autoantibodies in our study group.

Another point is that autoantibodies against FceRI $\alpha$ are detected in the sera of patients with different autoimmune diseases (such as SLE, dermatomyositis, pemphigus and pemphigoid); these antibodies are from subclasses $\operatorname{IgG} 2$ and IgG4, but they are functionally inactive ${ }^{[26]}$. In our study, elevated IgG4 levels were found in 7 patients treated for SLE.

Moreover, our 17 SAID patients with elevated IgG4 levels included 6 who suffered from different concomitant diseases which could cause the increase in the serum level of $\mathrm{IgG} 4$. In one patient, nodular sclerosis Hodgkin lymphoma (HL) was diagnosed histologically. HL cells frequently express interleukin 13 (IL-13) and its receptor. Besides exerting several effects on B cells (e.g., promoting their survival and proliferation), IL-13 switches the Ig class to $\mathrm{IgG} 4$ and $\mathrm{IgE}^{[27]}$. In another patient, bullous pemphigoid was identified, which is among the most common blistering autoimmune skin lesions. One of the features of the disease is the presence of autoantibodies against hemidesmosomal antigens (i.e., bullous pemphigoid antigen 1 and 2) in the serum and in affected areas of the skin. The major types of these autoantibodies are IgG4 and $\operatorname{Ig} \mathrm{E}^{[28]}$. In a third patient, cutaneous lymphocytic vasculitis was diagnosed, which could also explain the serum IgG4 elevation ${ }^{[29]}$. In 2 patients, the underlying disease was accompanied by Hashimoto's thyroiditis, which can elevate the IgG4 level since thyroglobulin autoantibodies 
are from subclasses $\operatorname{IgG} 2$ and $\mathrm{IgG} 4^{[30]}$. There was also one patient with bronchial asthma, in which disease elevated titers of $\operatorname{IgG} 4$ can be found ${ }^{[31]}$.

Finally, SS was diagnosed in the remaining 4 patients, one of whom was seronegative, while the others were seropositive. The elevated serum IgG4 level in patients with seronegative SS may possibly be explained by the presence of Mikulicz's disease ${ }^{[32]}$. Furthermore, an elevated serum IgG4 level has also been reported in $\mathrm{SS}^{[33]}$.

However, not all AIP patients display elevated serum IgG and IgG4 levels. IgG4-negative AIP patients seem to occur more frequently in Europe ${ }^{[34]}$. Furthermore, some AIP cases improve spontaneously ${ }^{[4]}$. Hence, it cannot be ruled out that our SAID cohort included AIP patients who were not diagnosed by the measurement of serum IgG4 or in whom the morphology of the pancreas had already normalized by the time of our examination.

Overall, it can be concluded that the serum IgG4 level may be elevated in SAIDs, but as a consequence of the concomitant SAID rather than of AIP. The determination of serum IgG4 does not seem to be suitable for the differentiation between IgG4-related diseases and SAIDs.

\section{COMMENTS}

\section{Background}

Autoimmune pancreatitis (AIP) is frequently associated with some other autoimmune disease, suggesting that it may be a systemic disorder. The determination of serum immunoglobulin G4 (IgG4) is a sensitive marker to diagnose AIP and lgG4-related diseases.

\section{Research frontiers}

$\lg$ G4 is a sensitive marker in the diagnosis of AIP. The association of AIP and systemic autoimmune diseases (SAIDs), and the usefulness of the determination of serum IgG4 in the diagnosis of AIP in patients with SAIDs are not defined.

\section{Innovations and breakthroughs}

The authors revealed that the serum IgG4 level may be elevated in SAIDs without the presence of AIP. The determination of serum IgG4 does not seem to be suitable for the differentiation between lgG4-related diseases and SAIDs.

\section{Applications}

This study provides important data about the serum level of lgG4 in SAIDs. The determination of serum IgG4 does not seem to be suitable for the differentiation between IgG4-related diseases and SAIDs. The diagnosis of AIP in SAIDs should be made on the results of morphological and histological examination.

\section{Terminology}

AIP is an increasingly recognized distinct type of chronic pancreatitis with a presumed autoimmune etiology. Immunoglobulin $\mathrm{G}(\mathrm{IgG})$ has four subclasses (IgG1 through $\lg \mathrm{G} 4$ ) and the lgG4 subclass accounts for $3 \%-6 \%$ of total serum lgG.

\section{Peer review}

This paper discusses the relationship between autoimmune pancreatitis and an elevated serum lgG4 level in autoimmune diseases, and presents interesting and potentially important information. The patients used in this study are few and biased (1 male and 60 female cases), but it is highly significant as a clinical pilot study. This study is well-designed and written, but there are some points to be clarified.

\section{REFERENCES}

1 Detlefsen S, Drewes AM. Autoimmune pancreatitis. Scand J Gastroenterol 2009; 44: 1391-1407

2 Shimosegawa T, Kanno A. Autoimmune pancreatitis in Japan: overview and perspective. J Gastroenterol 2009; 44 503-517

3 Park DH, Kim MH, Chari ST. Recent advances in autoim- mune pancreatitis. Gut 2009; 58: 1680-1689

4 Okazaki K, Kawa S, Kamisawa T, Ito T, Inui K, Irie H, Irisawa A, Kubo K, Notohara K, Hasebe O, Fujinaga Y, Ohara H, Tanaka S, Nishino T, Nishimori I, Nishiyama T, Suda K, Shiratori K, Shimosegawa T, Tanaka M. Japanese clinical guidelines for autoimmune pancreatitis. Pancreas 2009; 38 : 849-866

5 Hamano H, Kawa S, Horiuchi A, Unno H, Furuya N, Akamatsu T, Fukushima M, Nikaido T, Nakayama K, Usuda N, Kiyosawa K. High serum IgG4 concentrations in patients with sclerosing pancreatitis. N Engl J Med 2001; 344: 732-738

6 Choi EK, Kim MH, Lee TY, Kwon S, Oh HC, Hwang CY, Seo DW, Lee SS, Lee SK. The sensitivity and specificity of serum immunoglobulin G and immunoglobulin G4 levels in the diagnosis of autoimmune chronic pancreatitis: Korean experience. Pancreas 2007; 35: 156-161

7 Kamisawa T, Imai M, Egawa N, Tsuruta K, Okamoto A. Serum IgG4 levels and extrapancreatic lesions in autoimmune pancreatitis. Eur J Gastroenterol Hepatol 2008; 20: 1167-1170

8 Okazaki K, Uchida K, Koyabu M, Miyoshi H, Takaoka M. Recent advances in the concept and diagnosis of autoimmune pancreatitis and IgG4-related disease. J Gastroenterol 2011; 46: 277-288

9 Kamisawa T, Okamoto A. Autoimmune pancreatitis: proposal of IgG4-related sclerosing disease. J Gastroenterol 2006; 41: 613-625

10 Kamisawa T, Okazaki K, Kawa S, Shimosegawa T, Tanaka $\mathrm{M}$. Japanese consensus guidelines for management of autoimmune pancreatitis: III. Treatment and prognosis of AIP. I Gastroenterol 2010; 45: 471-477

11 Vitali C, Bombardieri S, Jonsson R, Moutsopoulos HM, Alexander EL, Carsons SE, Daniels TE, Fox PC, Fox RI, Kassan SS, Pillemer SR, Talal N, Weisman MH. Classification criteria for Sjögren's syndrome: a revised version of the European criteria proposed by the American-European Consensus Group. Ann Rheum Dis 2002; 61: 554-558

12 Gill JM, Quisel AM, Rocca PV, Walters DT. Diagnosis of systemic lupus erythematosus. Am Fam Physician 2003; 68: 2179-2186

13 Aletaha D, Neogi T, Silman AJ, Funovits J, Felson DT, Bingham CO, Birnbaum NS, Burmester GR, Bykerk VP, Cohen MD, Combe B, Costenbader KH, Dougados M, Emery P, Ferraccioli G, Hazes JM, Hobbs K, Huizinga TW, Kavanaugh A, Kay J, Kvien TK, Laing T, Mease P, Ménard HA, Moreland LW, Naden RL, Pincus T, Smolen JS, Stanislawska-Biernat E, Symmons D, Tak PP, Upchurch KS, Vencovský J, Wolfe F, Hawker G. 2010 Rheumatoid arthritis classification criteria: an American College of Rheumatology/European League Against Rheumatism collaborative initiative. Arthritis Rheum 2010; 62: 2569-2581

14 Walker JG, Pope J, Baron M, Leclercq S, Hudson M, Taillefer S, Edworthy SM, Nadashkevich O, Fritzler MJ. The development of systemic sclerosis classification criteria. Clin Rheumatol 2007; 26: 1401-1409

15 Chari ST, Smyrk TC, Levy MJ, Topazian MD, Takahashi N, Zhang L, Clain JE, Pearson RK, Petersen BT, Vege SS, Farnell MB. Diagnosis of autoimmune pancreatitis: the Mayo Clinic experience. Clin Gastroenterol Hepatol 2006; 4: 1010-1016; quiz 934

16 Hamano H, Arakura N, Muraki T, Ozaki Y, Kiyosawa K, Kawa S. Prevalence and distribution of extrapancreatic lesions complicating autoimmune pancreatitis. J Gastroenterol 2006; 41: 1197-1205

17 Naitoh I, Nakazawa T, Ohara H, Ando T, Hayashi K, Tanaka H, Okumura F, Miyabe K, Yoshida M, Sano H, Takada H, Joh T. Clinical significance of extrapancreatic lesions in autoimmune pancreatitis. Pancreas 2010; 39: e1-e5

18 Nirula A, Glaser SM, Kalled SL, Taylor FR. What is IgG4? A review of the biology of a unique immunoglobulin subtype. Curr Opin Rheumatol 2011; 23: 119-124 
19 van der Zee JS, van Swieten P, Aalberse RC. Inhibition of complement activation by IgG4 antibodies. Clin Exp Immunol 1986; 64: 415-422

20 Aalberse RC, Schuurman J. IgG4 breaking the rules. Immunology 2002; 105: 9-19

21 Church NI, Pereira SP, Deheragoda MG, Sandanayake N Amin Z, Lees WR, Gillams A, Rodriguez-Justo M, Novelli M, Seward EW, Hatfield AR, Webster GJ. Autoimmune pancreatitis: clinical and radiological features and objective response to steroid therapy in a UK series. Am J Gastroenterol 2007; 102: 2417-2425

22 Zamboni G, Lüttges J, Capelli P, Frulloni L, Cavallini G, Pederzoli P, Leins A, Longnecker D, Klöppel G. Histopathological features of diagnostic and clinical relevance in autoimmune pancreatitis: a study on 53 resection specimens and 9 biopsy specimens. Virchows Arch 2004; 445: 552-563

23 Raina A, Yadav D, Krasinskas AM, McGrath KM, Khalid A, Sanders M, Whitcomb DC, Slivka A. Evaluation and management of autoimmune pancreatitis: experience at a large US center. Am J Gastroenterol 2009; 104: 2295-2306

24 Czakó L, Gyökeres T, Topa L, Sahin P, Takács T, Vincze A, Dubravcsik Z, Szepes A, Pap A, Földesi I, Terzin V, Tiszlavicz L, Wittmann T. Autoimmune pancreatitis in Hungary: a multicenter nationwide study. Pancreatology 2011; 11 261-267

25 Yamamoto M, Harada S, Ohara M, Suzuki C, Naishiro Y, Yamamoto H, Takahashi H, Imai K. Clinical and pathological differences between Mikulicz's disease and Sjögren's syndrome. Rheumatology (Oxford) 2005; 44: 227-234

26 Fiebiger E, Hammerschmid F, Stingl G, Maurer D. AntiFcepsilonRIalpha autoantibodies in autoimmune-mediated disorders. Identification of a structure-function relationship. J Clin Invest 1998; 101: 243-251
Skinnider BF, Elia AJ, Gascoyne RD, Trümper LH, von Bonin F, Kapp U, Patterson B, Snow BE, Mak TW. Interleukin 13 and interleukin 13 receptor are frequently expressed by Hodgkin and Reed-Sternberg cells of Hodgkin lymphoma. Blood 2001; 97: 250-255

28 Döpp R, Schmidt E, Chimanovitch I, Leverkus M, Bröcker EB, Zillikens D. IgG4 and IgE are the major immunoglobulins targeting the NC16A domain of BP180 in Bullous pemphigoid: serum levels of these immunoglobulins reflect disease activity. J Am Acad Dermatol 2000; 42: 577-583

29 Kawassaki AM, Haga H, Dantas TC, Musolino RS, Baldi BG, Carvalho CR, Kairalla RA, Mauad T. Adenopathy and pulmonary infiltrates in a Japanese emigrant in Brazil. Chest 2011; 139: 947-952

30 Fukuma N, McLachlan SM, Petersen VB, Kau P, Bradbury J, Devey M, Bleasdale K, Grabowski P, Smith BR. Human thyroglobulin autoantibodies of subclasses IgG2 and IgG4 bind to different epitopes on thyroglobulin. Immunology 1989; 67 : 129-131

31 Sprangers B, Claes K. IgG4-related disease should be considered in cases of hypocomplementemic immune-complex tubulointerstitial nephritis. Letters and Replies NDT Plus 2010; 3: 326-334

32 Masaki Y, Sugai S, Umehara H. IgG4-related diseases including Mikulicz's disease and sclerosing pancreatitis: diagnostic insights. J Rheumatol 2010; 37: 1380-1385

33 Suzuki S, Kida S, Ohira Y, Ohba T, Miyata M, Nishimaki T, Morito T, Kasukawa R, Hojyo H, Wakasa H. [A case of Sjögren's syndrome accompanied by lymphadenopathy and IgG4 hypergammaglobulinemia]. Ryumachi 1993; 33: 249-254

34 Kamisawa T, Takuma K, Tabata T, Inaba Y, Egawa N, Tsuruta K, Hishima T, Sasaki T, Itoi T. Serum IgG4-negative autoimmune pancreatitis. J Gastroenterol 2011; 46: 108-116

S- Editor Cheng JX L- Editor Cant MR E- Editor Xiong L 
Annex III. 
Original article

\title{
Improved glycemic control in pancreatic diabetes through intensive conservative insulin therapy
}

\author{
Viktória Terzin $^{\mathrm{a}}$, Róbert Takács ${ }^{\mathrm{a}}$, Csaba Lengyel $^{\mathrm{a}}$, Tamás Várkonyi ${ }^{\mathrm{a}}$, Tibor Wittmann ${ }^{\mathrm{a}}$, Attila Pálinkás ${ }^{\mathrm{b}}$, \\ László Czakó ${ }^{\mathrm{a}, *}$ \\ ${ }^{a}$ First Department of Medicine, University of Szeged, Szeged, P.O. Box 427, H-6701, Hungary \\ ${ }^{\mathrm{b}}$ Erzsébet Hospital, Hódmezővásárhely, Hungary
}

\section{Keywords:}

Pancreatic diabetes

Chronic pancreatitis

Glycemic control

Insulin

Oral antidiabetic medication

Pancreatic enzyme replacement

\begin{abstract}
A B S T R A C T
Objective: The aim of this study was to evaluate the effectivity and safety of insulin therapy in patients with DM secondary to underlying chronic pancreatitis with initially inappropriate glycemic control. Methods: Pancreatic DM patients treated with oral antidiabetics (OAD) or pre-mixed insulin (PMI) with $\mathrm{HbA1c} \geq 7.0 \%$ were recruited. Intensive conservative insulin treatment (ICT) (Group A, $n=16$ ) or PMI (Group B, $n=8$ ) was introduced instead of OAD, or the initial PMI therapy was switched to ICT (Group C, $n=10$ ). The changes in HbA1c, fasting plasma glucose, body weight and hypoglycemic events from baseline to 2 years were followed.

Results: The patients in Group A and B had been treated with oral antidiabetics for $55 \pm 68$ months before switching to insulin therapy. The level of HbA1c had worsened from $8.3 \pm 1.5 \%$ to $9.8 \pm 1.7 \%$ during this period. The ICT had reduced HbA1c significantly from $9.7 \pm 1.8 \%$ to $7.6 \pm 1.4 \%$ after 12 weeks, in Group A, and five patients had HbA1c $<7.0 \%$. The introduction of PMI in Group B reduced HbA1c from $10.0 \pm 1.4 \%$ to $9.0 \pm 0.6 \%$ by 12 weeks. None of the patients had HbA1c $<7.0 \%$. By 12 weeks, the introduction of ICT in Group $C$ had reduced the level of $\mathrm{HbA} 1 \mathrm{c}$ from $8.8 \pm 1.7 \%$ to $7.7 \pm 1.2 \%$. Two patients reached $\mathrm{HbA} 1 \mathrm{c}<7.0 \%$. There were two severe hypoglycemic episodes during the 2 years, one-one case in Group A and B. Conclusions: Oral medication becomes insufficient early in pancreatic DM. Long-term improvement of glycemic control can be achieved through intensified insulin therapy and in selected cases through PMI with a low risk of hypoglycemia.
\end{abstract}

Copyright (c) 2012, IAP and EPC. Published by Elsevier India, a division of Reed Elsevier India Pvt. Ltd. All rights reserved.

\section{Introduction}

Pancreatic diabetes mellitus (DM) develops from impairment of the pancreatic endocrine function due to the progression of a pancreatic disease such as acute or chronic pancreatitis $(\mathrm{CP})$, pancreatic surgery or pancreatic carcinoma [1-3]. The World Health Organization has distinguished pancreatic DM from types 1 and $2 \mathrm{DM}$ and classified it as a specific subtype (type 3c) [4].

The reported prevalence of DM in CP varies between 30 and $83 \%$ $[2,3,5,6]$. Overall, exocrine pancreatic diseases are believed to be responsible for DM in around $8 \%$ of the cases, but in as many as $15-20 \%$ of DM patients in South-East Asia, where tropical pancreatitis is endemic [7]. However, the prevalence of CP may be much higher than previously estimated in the general population, and

\footnotetext{
* Corresponding author. Tel.: +36 62 545187; fax: +36 62545185 .

E-mail address: czako.laszlo@med.u-szeged.hu (L. Czakó).
}

DM secondary to CP could be more common, which would explain the frequent finding of an exocrine pancreatic insufficiency in diabetics $[8,9]$.

Insulin $(\beta)$, glucagon $(\alpha)$, pancreatic polipeptid (PP) and somatostatin $(\delta)$ producing cells are destroyed in pancreatic DM [10-13]. The pathomechanism and clinical features of pancreatic DM therefore differ from those of types 1 and 2 DM, and the principles of its treatment may also differ [5]. However, there appears to be a lack of consensus regarding the management of patients with pancreatic DM [14], as they do not fit into either the type 1 or 2 DM guidelines recommended by professional bodies $[15,16]$. All the large clinical trials, including UK Prospective Diabetes Study (UKPDS) and Diabetes Control and Complications Trial (DCCT), specifically excluded patients with pancreatic DM; accordingly data are lacking as concerns modern evidence-based practice in this group of patients. The first and most important defensive mechanism against hypoglycemia is glucagon secretion. The risk of hypoglycemia in pancreatic DM is increased due to the 
absence of glucagons, alcohol consumption, inadequate nutrition and impaired nutrient absorption due to an exocrine pancreatic insufficiency.

The aim of this study was to evaluate the effectivity of insulin therapy from the aspects of glycemic control, body weight and safety in patients with DM secondary to underlying CP with initially inappropriate glycemic control. The study was performed in a university hospital, where pancreatologists and diabetologists work together.

\section{Methods and patients}

Pancreatic DM patients, in whom DM was developed secondary to underlying CP and having $\mathrm{HbA} 1 \mathrm{c} \geq 7.0 \%$, between 1 January 2007 and 31 December 2010 were recruited in the study. Depending on the antidiabetic therapy administered up to the time of recruitment, the patients were divided into three groups. In Groups A and $\mathrm{B}$, the baseline antidiabetic therapy was oral medication, while in Group C it was pre-mixed insulin (PMI) (Table 1). Because of the inappropriate glycemic control, the initial oral medications was switched to intensive conservative insulin treatment (short-acting insulin three times per day before meals and an intermediateacting insulin injection before sleep/ICT/) in Group A and to twice daily PMI in Group B. Poor compliance or the loss of sight was the reason for the change to PMI instead of ICT in Group B. The initial PMI therapy was switched to ICT in Group C. All patients were on pancreatic enzyme replacement therapy in the $3-5 \times 25.000-75.000$ IU doses of pancreatin.

The indications for the previous introduction of oral antidiabetic drugs to our cohort can be explained retrospectively as follows: (1) the plasma glucose level was only slightly increased, to a level which is usually normalized by oral antidiabetic drugs in everyday practice, (2) the fear of severe hypoglycemia, (3) undiscovered pancreatic disease or the undetected association between pancreatic disease and DM.

The changes in HbA1c, fasting plasma glucose, body weight and hypoglycemic events were followed from baseline to 2 years.

$\mathrm{CP}$ was diagnosed on the bases of morphological and functional diagnostic criteria [17].

The diagnosis of DM was established in accordance with the criteria of the American Diabetes Association [4]. Patients with cystic fibrosis were excluded from the study.

All patients provided written informed consent. The study protocol was in full accordance with the most recent revisions of the Helsinki Declaration and was approved by the ethics committee of University of Szeged.

Experimental data were evaluated statistically with the pairedsamples $t$ test. $P$ values $<0.05$ were accepted as being statistically significant. Statistical data is expressed as mean $\pm \mathrm{SD}$.

\section{Results}

A total of 297 patients with CP were admitted to our department in the 4-year period, 112 of them suffered from pancreatic DM. 30 pancreatic DM patients ( 24 male, 6 female, mean age: $56.4 \mathrm{y}$, range: 36-76 y) with HbA1c $\geq 7.0 \%$ were recruited; 16 cases in Group A, 8 cases in Group B, and 10 cases in Group C (Table 1). Because of the inappropriate glycemic control (HbA1c $>9 \%$ ) after the 2-year follow-up period four patients were rearranged into the Group $C$. The duration of $\mathrm{CP}$ was over 10 years. $47 \%$ of the patients had previously undergone pancreatic surgery and 63\% of them presented with calcifications in the pancreas. The etiology involved chronic alcohol abuse in $63 \%$ of the cases (Table 1).

There was a great variety in the prior medication of the patients in Groups A and B: metformin or sulfonylurea alone; metformin
Table 1

Clinical characteristics of pancreatic diabetic patients.

\begin{tabular}{llll}
\hline & Group A & Group B & Group C \\
\hline Patient (cases) & 16 & 8 & 10 \\
Male/female & $14 / 2$ & $5 / 3$ & $7 / 3$ \\
Age mean (range) (y) & $54.1(36-76)$ & $60.6(46-76)$ & $58.6(37-76)$ \\
Weight mean (range) (kg) & $72.1(60-103.3)$ & $72.7(40.5-94)$ & $77.4(59-104)$ \\
$\begin{array}{c}\text { Duration of chronic } \\
\text { pancreatitis (mean) (y) }\end{array}$ & $9.4 \pm 6.2$ & $15.9 \pm 6.5$ & $16.9 \pm 8.8$ \\
$\begin{array}{l}\text { Pancreatic surgery (cases) } \\
\text { Calcification (cases) }\end{array}$ & $7 / 16$ & & \\
Alcoholic etiology & $13 / 16$ & $3 / 8$ & $6 / 10$ \\
Duration of diabetes & $9.2 \pm 4.0$ & $4 / 8$ & $4 / 10$ \\
$\quad$ (mean) (y) & & $14.5 \pm 5.4$ & $5 / 10$ \\
HbA1c mean (range) (\%) & $9.7 \pm 1.8$ & $10.0 \pm 1.4$ & $8.8 \pm 1.7$ \\
\hline
\end{tabular}

and sulfonylurea in combination; sulfonylurea and acarbose in combination; metformin, sulfonylurea and acarbose in a triple combination or metformin, sulphonylurea, acarbose and glitazone in quartet combination (Table 2). On average, these patients had been treated with oral antidiabetics for $55 \pm 68$ months before switching to insulin. The level of HbA1c had worsened significantly by $18.1 \%$ (from $8.3 \pm 1.5 \%$ to $9.8 \pm 1.7 \%, p<0.05$ ) during this period.

After 12 weeks, the introduction of ICT in Group A had significantly reduced the fasting plasma glucose by $29 \%$ (from $13.0 \pm 3.9 \mathrm{mmol} / \mathrm{l}$ to $9.2 \pm 2.1 \mathrm{mmol} / \mathrm{l}, p<0.002$ ) (Fig. $1 \mathrm{~A}$ ) and HbA1c by $22 \%$ (from $9.7 \pm 1.8 \%$ to $7.6 \pm 1.4 \%, p<0.001$ ) (Fig. $1 \mathrm{~B}$ ). Five patients had $\mathrm{HbA1c}<7.0 \%$. By 2 years, both the blood glucose and HbA1c had further decreased significantly to $8.0 \pm 2.2 \mathrm{mmol} / \mathrm{l}$ $(p<0.001)$ and to $7.4 \pm 1.4 \%(p<0.003)$, respectively. The body weight did not change significantly during the 2 years of therapy ( $72.1 \mathrm{vs} 72.9 \mathrm{~kg}, p=0.708$ ). With the exception of one patient who was a habitual drinker, none of the patients reported any severe hypoglycemic episode (i.e. requiring external assistance) or was hospitalized for hypoglycemia, though minor hypoglycemic attacks with good warning were documented.

After 12 weeks, the introduction of PMI twice a day in Group B had reduced the fasting plasma glucose by $12 \%$ (from $13.2 \pm 3.1$ to $11.6 \pm 2.9 \mathrm{mmol} / \mathrm{l}),(p=0.190)$ (Fig. $1 \mathrm{~A}$ ) and HbA1c by $10 \%$ (from $10.0 \pm 1.4 \%$ to $9.0 \pm 0.6 \%),(p=0.291$ ), but not significantly (Fig. $1 \mathrm{~B}$ ). The blood glucose and HbA1c had improved further: $(10.2 \pm 2.2 \mathrm{mmol} / \mathrm{l}(p=0.07)$ and $8.6 \pm 0.9 \%(p=0.23)$, respectively) by 2 years, though none of the patients had a HbA1c level $<7.0 \%$. The body weight did not change significantly (72.7 vs $71.6 \mathrm{~kg}, p=0.796)$.

After 12 weeks, the introduction of ICT in Group $C$ had reduced the fasting plasma glucose by $19 \%$ (from $12.2 \pm 3.3 \mathrm{mmol} / \mathrm{l}$ to $9.9 \pm 2.5 \mathrm{mmol} / \mathrm{l}),(p=0.127)$ (Fig. $1 \mathrm{~A}$ ) and the level of HbA1c by $13 \%$ (from $8.8 \pm 1.7 \%$ to $7.7 \pm 1.2)$, $(p<0.04)$, the latter significantly (Fig. 1B). Two patients reached HbA1c $<7.0 \%$. By 2 years, the blood glucose remained stable $(9.8 \pm 3.1 \mathrm{mmol} / \mathrm{l}, p=0.139)$, but HbA1c had decreased further, significantly $(7.6 \pm 1.2 \%, p<0.04)$ (Fig. 1A and B). The body weight of these patients did not change significantly during the 2 years of therapy $(77.4$ vs $79.1 \mathrm{~kg}$,

Table 2

Initial pharmacological treatment used in patients with pancreatic diabetes in Group $\mathrm{A}$ and $\mathrm{B}$.

\begin{tabular}{lr}
\hline Treatment & $N$ \\
\hline Metformin alone & 4 \\
Sulphonylurea alone & 12 \\
Metformin and sulphonylurea combination & 3 \\
Sulphonylurea and acarbose combination & 2 \\
Metformin, sulphonylurea and acarbose combination & 2 \\
Metformin, sulphonylurea, acarbose and glitazone combination & 1 \\
\hline
\end{tabular}


A

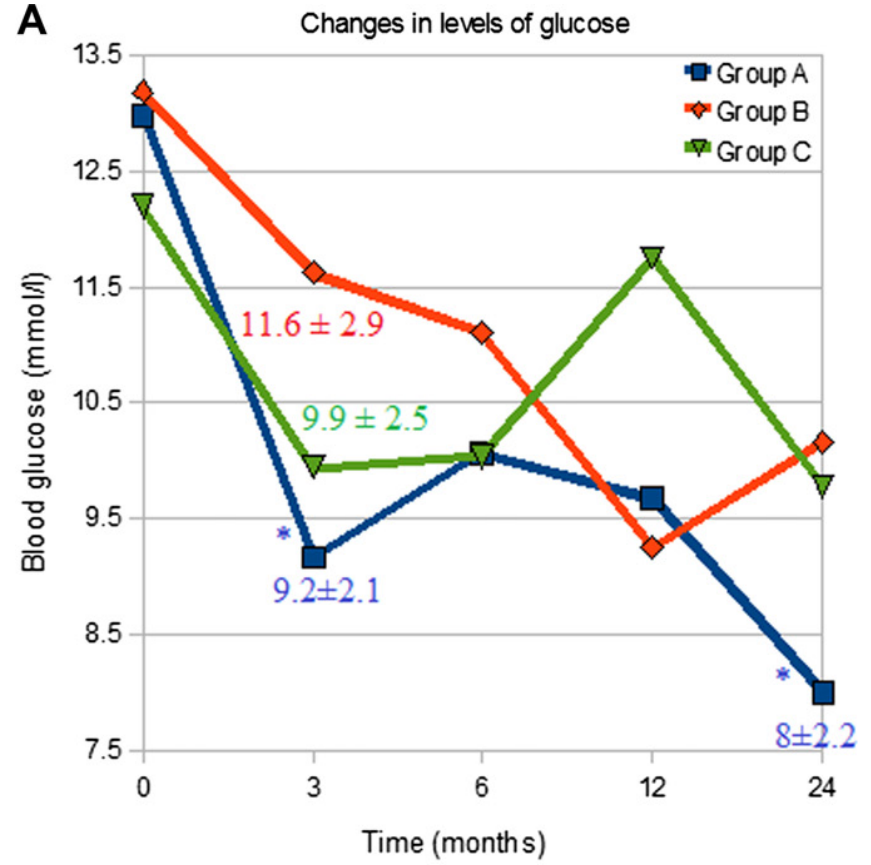

B

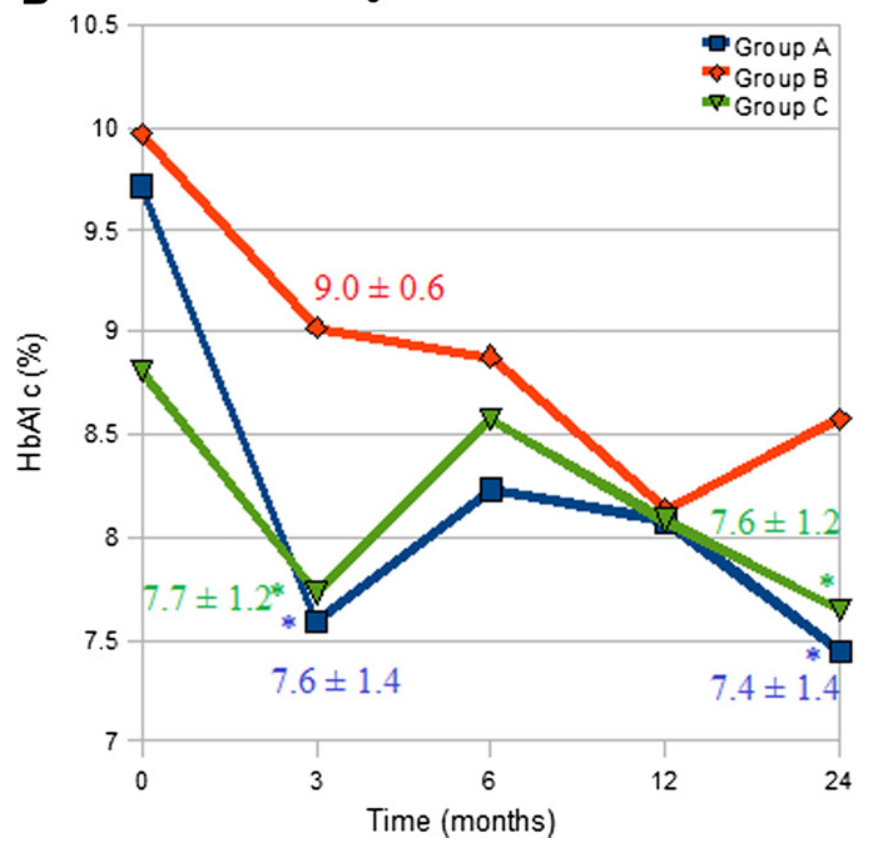

Fig. 1. Efficacy of insulin therapy in pancreatic diabetes. Changes in fasting plasma glucose (A) and HbA1c (B) after the introduction of intensive conservative insulin therapy (Group A) or twice daily premix insulin (Group B) instead of oral medication. The initial premix insulin therapy was switched to intensive conservative insulin therapy in Group C. * significant difference $(p<0.05)$ vs baseline.

$p=0.498)$. With the exception of one case on PMI therapy because of a concomitant viral infection, no severe hypoglycemic episode or hospitalization was necessary due to hypoglycemia in Groups B and $\mathrm{C}$.

The daily average dose of insulin in Groups A, B and C was $30.4 \pm 11.8,29.9 \pm 12.4$ and $40.1 \pm 8.1 \mathrm{IU}$, respectively. The better glycemic control required a higher amount of insulin during ICT as compared with the initial PMI therapy in Group C (38.4 \pm 12.6 vs $40.1 \pm 8.14 \mathrm{IU}, p=0.91$ ).

\section{Discussion}

The present study has demonstrated that long-term improvement of glycemic control was achieved without the risk of hypoglycemia in our cohort of pancreatic DM patients through the use of insulin therapy.

No evidence-based study relating to treatment practice in pancreatic DM has been reported to date. All the large clinical trials, including UKPDS and DCCT, specifically excluded patients with pancreatic DM $[15,16]$. Some authors suggest a trial of oral antidiabetic agents followed by insulin therapy when the need arises $[18,19]$. However, insulin sensitizers (biguanides and glitazones) and the carbohydrate absorption inhibitor $\alpha$-glucosidase should be avoided in pancreatic DM since the major pathogenetic defect is a lack of insulin and because of the coexisting maldigestion and consequent leanness. Furthermore, their side-effects (bloating, diarrhea and abdominal pain) would add to the similar symptoms caused by CP. Since patients with pancreatic DM may occasionally be capable of insulin secretion, sulphonylureas may initially be of benefit. However, $\mathrm{CP}$ is a progressive disorder and the use of sulphonylureas can accelerate the exhaustion of beta-cells. Indeed, in our patients who had received sulfonylurea medication, glycemic control became inappropriate much earlier than as secondary sulfonylurea failure develops in type 2 DM [20]. Furthermore, sulfonylurea may cause hypoglycemia and is often contraindicated due to the accompanying liver disease [3]. Overall, the application of oral antidiabetic drugs in pancreatic DM is generally not recommended.

The primary hormonal abnormality in pancreatic DM is decreased insulin secretion [1-3]. Moreover, pancreatic DM is considered to be a result not merely of impaired insulin production, but also of coexisting hepatic insulin resistance and alterations in insulin action $[13,21]$. The loss of counterregulatory hormones from the pancreas (e.g. somatostatin and glucagon) makes difficult to achieve good glycemic control in pancreatic DM. The maldigestion of carbohydrates due to the coexisting pancreatic exocrine insufficiency, the concomitant alcohol consumption and hepatic disease, the lack of compliance with the prescribed diet and/or medical therapy, and the enhanced intestinal transit further hamper the appropriate glycemic treatment of these patients [3]. These factors may lead to frequent, severe and unpredictable hypoglycemic episodes that may prove lethal in patients on insulin $[5,22]$. However, in contrast with previous observations [5], our study revealed that severe hypoglycemia was not a common problem in patients with pancreatic DM treated with insulin. Furthermore, the frequency of hypoglycemia in patients who continued to consume alcohol was clearly higher than in patients who had stopped drinking [5]. Accordingly, ICT should be administered only to selected patients who do not consume alcohol and display compliance.

Patients with pancreatic DM display deficiencies in both basal and postprandial insulin secretion. To mimic physiological insulin secretion, the supplementation of prandial and basal insulin levels is important. The clinical efficacy of a multiple-insulin-injection regimen in pancreatic DM has been reported [23]. It is suggested that insulin therapy should be started in pancreatic DM as early as possible, when the beta-cells are still capable of secreting insulin $[24,25]$. The introduction of early insulin therapy promotes the maximal preservation of the patient's own insulin secretion. The preserved endogenous insulin secretion can adapt to the changing plasma glucose level, with the consequence that these patients are less prone to hypoglycemia, and glycemic control is more stable.

The administration of long-acting insulin twice a day is usually not recommended in pancreatic DM, because of the possibility of 
interference and the danger of severe hypoglycemia [26]. However, as long as the beta-cells are capable of secreting insulin, glycemic control may be accomplished by twice a day administration of intermediate or PMI. Indeed, in our selected cases (Group B), good glycemic control was achieved without the risk of hypoglycemia by means of the twice a day administration of PMI. However, to accomplish the recommended glycemic control in Group C, intensified insulin therapy was needed instead of twice daily PMI. This regime preserves the endogenous insulin secretion, and can easily be adapted to the daily activities in cooperating patients.

All of our patients demonstrated reduced HbA1c level after the induction of ICT or PMI (Fig. 1B). The extents of reduction of HbA1C after 3 months in Groups A, B and C were 22, 10, 13\%, respectively. Furthermore, stable long-term control of the blood glucose and HbA1c levels was attained with insulin therapy by 2 years.

In summary, the present study suggests that, though oral medication may become insufficient early in pancreatic DM. The best long-term glycemic control can be achieved without the risk of hypoglycemia through intensified insulin therapy and in selected cases with PMI.

\section{Acknowledgments} KONV.

This work was partly supported by the TÁMOP-4.2.1./B-09/1/

\section{References}

[1] Owyang C. Endocrine changes in pancreatic insufficiency. In: Go VLW, Di Magno EP, editors. The pancreas: biology, pathobiology and diseases. New York: Raven Press; 1993. p. 803-13.

[2] Angelopoulos N, Dervenis C, Goula A, Rombopoulos G, Livadas S, Kaltsas D, et al. Endocrine pancreatic insufficiency in chronic pancreatitis. Pancreatology 2005;5:122-31

[3] Czakó L, Hegyi P, Rakonczay Z, Wittmann T, Otsuki M. Interactions between the endocrine and exocrine pancreas and its clinical relevance. Pancreatology 2009;9:351-9.

[4] American Diabetes Association. Diagnosis and classification of diabetes mellitus. Diabetes Care 2007;30:S42-7.

[5] Ito T, Otsuki M, Igarashi H, Kihara Y, Kawabe K, Nakamura T, et al. Epidemiological study of pancreatic diabetes in Japan in 2005. A nationwide study. Pancreas 2010;39:829-35.

[6] Malka D, Hammel P, Sauvanet A, Rufat P, O'Toole D, Bardet P, et al. Risk factors of diabetes mellitus in chronic pancreatitis. Gastroenterology 2000;119: $1324-32$
[7] Mohan V, Barman KK, Rajan VS, Chari ST, Deepa R. Natural history of endocrine failure in tropical chronic pancreatitis: a longitudinal follow-up study. J Gastroenterol Hepatol 2005;20:1927-34.

[8] Hardt PD, Brendel MD, Kloer HU, Bretzel RG. Is pancreatic diabetes (type 3c diabetes) underdiagnosed and misdiagnosed? Diabetes Care 2008;31(Suppl. 2):S165-9.

[9] Ewald N, Kaufmann C, Raspe A, Kloer HU, Bretzel RG, Hardt PD. Prevalence of diabetes mellitus secondary to pancreatic diseases (type 3c). Diabetes Metab Res Rev; 2011 Nov 26:2260. doi:10.1002/dmrr [Epub ahead of print].

[10] Donowitz M, Hendler R, Spiro HM, Binder HJ, Felig P. Glucagon secretion in acute and chronic pancreatitis. Ann Intern Med 1975;83:778-81.

[11] Valenzuela JE, Taylor IL, Walsh JH. Pancreatic polypeptide response in patients with chronic pancreatitis. Dig Dis Sci 1979;24:862-4.

[12] Govindarajan M, Mohan V, Deepa R, Ashok S, Pitchumoni CS. Histopathology and immunohistochemistry of pancreatic islets in fibrocalculous pancreatic diabetes. Diabetes Res Clin Pract 2001;51:29-38.

[13] Andersen DK. Mechanisms and emerging treatments of the metabolic complications of chronic pancreatitis. Pancreas 2007;35:1-15.

[14] Price S, Cole D, Alcolado JC. Diabetes due to exocrine pancreatic disease a review of patients attending a hospital-based diabetes clinic. QJ Med 2010; 103:759-63.

[15] Nathan DM, Buse JB, Davidson MB, Heine RJ, Holman RR, Sherwin R, et al. Medical management of hyperglycaemia in type 2 diabetes mellitus: a consensus algorithm for the initiation and adjustment of therapy: a consensus statement from the American Diabetes Association and the European Association for the study of diabetes. Diabetologia 2009;52:17-30.

[16] European Diabetes Policy Group. A desktop guide to type 1 (insulin-dependent) diabetes mellitus. Diab Med 1998;1999(16):253-66.

[17] DiMagno MJ, DiMagno EP. Chronic pancreatitis. Curr Opin Gastroenterol 2010; 26:490-8.

[18] Choudhuri G, Lakshmi CP, Goel A. Pancreatic diabetes. Trop Gastroenterol 2009;30:71-5.

[19] Cui Y, Andersen DK. Pancreatogenic diabetes: special considerations for management. Pancreatol 2011;11:279-94.

[20] Satoh J, Takahashi K, Takizawa Y, Ishihara H, Hirai M, Katagiri H, et al. Secondary sulfonylurea failure: comparison of period until insulin treatment between diabetic patients treated with gliclazide and glibenclamide. Diabetes Res Clin Pract 2005;70:291-7.

[21] Cavallini G, Vaona B, Bovo P, Cigolini M, Rigo L, Rossi F. Diabetes in chronic alcoholic pancreatitis. Role of residual beta cell function and insulin resistance. Dig Dis Sci 1993;38:497-501.

[22] Sjoberg RJ, Kidd GS. Pancreatic diabetes mellitus. Diabetes Care 1989;12: 715-24.

[23] Miura J, Yokoyama J, Miura A, Mori Y, Ito K, Ikeda Y. Clinical efficacy of multiple insulin injection regimen in pancreatogenic diabetes (in Japanese). J Jpn Diabet Soc 1991;34:685-91.

[24] Gerő LA. pancreatogen diabetes okai, tünettana és kezelése. Diabetologia Hungarica 2002;10(Suppl. 3):19-22.

[25] Kawabe K, Ito T, Igarashi H, Takayanagi R. The current managements of pancreatic diabetes in Japan. Clin J Gastroenterol 2009;2:1-8.

[26] Starke AAR, Cupers HJ, Berger M. Therapeutic problems in diabetes secondary to pancreopathy. In: Tiengo A, Alberti KGMM, Del Prato S, Vranic M, editors. Diabetes secondary to pancreopathy. Amsterdam: Excerpta Medica; 1988. p. 227-33. 
Annex IV. 


\section{Inzulinkezelés pancreatogen diabetes mellitusban*}

Terzin Viktória dr., ${ }^{(1)}$ Takács Róbert dr., ${ }^{(1)}$ Lengyel Csaba dr., ${ }^{(1)}$ Várkonyi Tamás dr., Wittmann Tibor dr., ${ }^{(1)}$ Pálinkás Attila dr., ${ }^{(2)}$ Czakó László dr. ${ }^{(1)}$

\footnotetext{
* A közlemeny a Terzin V, Takàcs R, Lengyel Cs, Várkonyi T, Wittmann T, Pálinkás A, Czakó L: mproved glycemic control in pancreatic diabetes through intensive insulin therapy. Pancreatology 2012; 12: 100-103. cikk magyar nyelvü másodközlése.
}

\section{Összefoglalás}

A pancreatogen diabetes mellitus patomechanizmusa és kezelése eltér az egyéb etiológiájú cukorbetegségekétöl. A terápiára vonatkozóan nincs konszenzus, s nem áll rendelkezésre klinikai vizsgálatokon alapuló evidencia sem. A szerzök vizsgálatának célja az inzulinterápia hatásosságának tanulmányozása a glykaemiás kontroll és a hypoglykaemia előfordulási gyakoriságának tükrében azoknál a betegeknél, akiknél a diabetes mellitus krónikus pancreatitis szövödményeként alakult ki és a cukoranyagcsere nem volt megfelelöen beállitva. A vizsgálat során azon pancreatogen diabeteses betegeket választották be, akik orális antidiabetikus vagy premixinzulin-kezelés alatt álltak és $\mathrm{HbA}_{1 c}$-értékük elérte vagy meghaladta a 7,0\%-ot. A vizsgálat során az orális antidiabetikus kezelést intenzifikált inzulinterápiára (A csoport, $n=16$ ) vagy premix inzulinra (B csoport, $n=8$ ), mig a kezdeti premixinzulin-terápiát intenzifikált inzulinkezelésre (C csoport, $n=10)$ állították át. Két éven át követték a $\mathrm{HbA}_{1 c}$ az éhomi vércukor és a testsúly változását, valamint a hypoglykaemiás események gyakoriságát. Az A és B csoport betegei a terápiamódositás elött $55 \pm 68$ hónapon keresztül álltak orális antidiabetikus kezelés

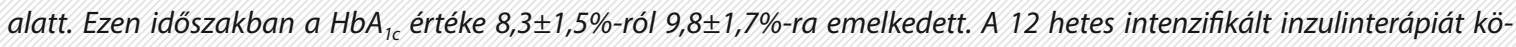

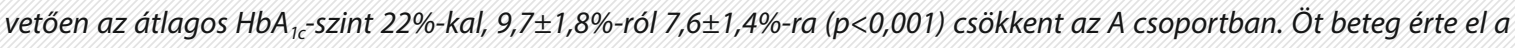

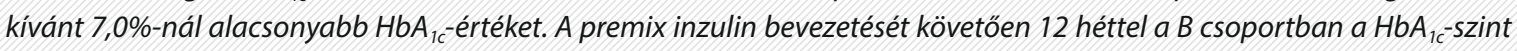
$10,0 \pm 1,4 \%$-ról 9,0 0,6\%-ra ( $p=0,291)$ változott, vagyis csak 10\%-kal, de nem szignifikáns mértékben csökkent. A betegek közül senki sem érte el a $7,0 \%$ alatti $\mathrm{HbA}_{1 c}$-értéket. A C csoportban az intenzifikált inzulinkezelés 12 hete alatt a HbA $1 \mathrm{c} 13 \%$ -

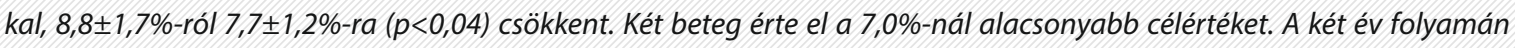
két súlyos hypoglykaemiás epizód zajlott le a vizsgált betegek között. A vizsgálat eredményei megerösítik, hogy az orális antidiabeticumok pancreatogen diabetes mellitusban hamar elégtelennek bizonyulnak. A szerzök eredményei igazolják, hogy kielégitö hosszú távú glykaemiás kontroll érhetö el intenzifikált inzulinterápia segítségével. A súlyos hypoglykaemia veszélye csekély. A megfelelö pancreasenzim-pótlás elengedhetetlen.

- Kulcsszavak: pancreatogen diabetes, krónikus pancreatitis, glykaemiás kontroll, inzulin, orális antidiabetikus kezelés, pancreasenzim-szubsztitúció

\section{Improved glycemic control in pancreatic diabetes through intensive insulin therapy}

The management of pancreatic diabetes mellitus lacks consensus, as it does not fit into either the type 1 or 2 diabetes guidelines. The aim of this study was to evaluate the effectivity of insulin therapy as concerns glycemic control and safety in patients with diabetes secondary to underlying chronic pancreatitis with initially inappropriate glycemic control. Patients suffered from pancreatic diabetes mellitus and treated with oral antidiabetics or pre-mixed insulin with $\mathrm{HbA}_{1 c} \geq 7.0 \%$ were 
recruited in the study. Intensive insulin therapy (Group $A, n=16$ ) or pre-mixed insulin (Group $B, n=8$ ) was introduced instead of oral antidiabetics, or the initial pre-mixed insulin therapy was switched to intensive insulin therapy $(G r o u p C, n=10)$. The changes in $\mathrm{HbA}_{1 \mathrm{c}}$ fasting plasma glucose, body weight and hypoglycemic events from baseline to 2 years were followed. The patients in Group A and B had been treated with oral antidiabetics for $55 \pm 68$ months before switching to insulin therapy. The level of $\mathrm{HbA}_{1 \mathrm{c}}$ had worsened from $8.3 \pm 1.5 \%$ to $9.8 \pm 1.7 \%$ during this period. The intensive insulin therapy had reduced $\mathrm{HbA}_{1 c}$ by $22 \%$ (from $9.7 \pm 1.8 \%$ to $7.6 \pm 1.4 \%, \mathrm{p}<0.001$ ) after 12 weeks, in Group $\mathrm{A}$, and 5 patients had $\mathrm{Hb} \mathrm{A}_{1 \mathrm{c}}$ $<7.0 \%$. The introduction of pre-mixed insulin in Group B did not reduced $H b A_{1 c}$ significantly (from $10.0 \pm 1.4 \%$ to $9.0 \pm 0.6 \%$, $p=0.291$ ) by 12 weeks. None of the patients had $\mathrm{HbA},<7.0 \%$. By 12 weeks, the introduction of intensive insulin therapy in Group C had reduced the level of $\mathrm{HbA}_{1 c}$ by $13 \%$ (from $8.8 \pm 1.7 \%$ to $7.7 \pm 1.2 \%, \mathrm{p}<0.04$ ). Two patients reached $\mathrm{Hb} \mathrm{A}_{1 c}<7.0 \%$. There were two severe hypoglycemic episodes during the 2 years. Oral medication becomes insufficient early in pancreatic diabetes mellitus. The results of this study show that adequate long-term glycemic control can be achieved through intensified insulin therapy with a low risk of hypoglycemia. Appropriate pancreatic exocrine replacement therapy is important.

Key words: pancreatic diabetes, chronic pancreatitis, glycemic control, insulin, oral antidiabetic medication, pancreatic enzyme replacement

\section{DIABETOLOGIA HUNGARICA 20 (№3) 171-178. 2012. szeptember}

Rövidítések

KP: krónikus pancreatitis (chronic pancreatitis); DCCT: Diabetes Control and Complications Trial; DM: diabetes mellitus; ICT: intenzív konzervatív inzulinkezelés (intensive conservative insulintherapy); OAD: orális antidiabeticum (oral antidiabetics); PMI: premix inzulin (pre-mixed insulin); UKPDS: UK Prospective Diabetes Study

A pancreatogen diabetes mellitus (DM) a hasnyálmirigy exokrin betegségei következtében kialakuló cukorbetegség. Okozhatja az akut vagy a krónikus pancreatitis (KP) progressziója, cystás fibrosis, de eredményezheti pancreasmütét és malignus folyamat is. ${ }^{1,2,3,4} \mathrm{~A}$ WHO a pancreatogen DM-et megkülönbözteti az 1-es és 2-es típusú DM-től és a diabetes egy külön alcsoportjának tekinti (3c típusú DM). ${ }^{5}$

A DM 30 és 83\% közötti gyakorisággal fordul elő krónikus pancreatitisben, függően a betegség etiológiájától, időtartamától és a meszesedés jelenlététől. ${ }^{2,3,6,7}$ Általánosságban elmondható, hogy az exokrin pancreas betegségei a DM kialakulásának kb. 8\%-áért tehetők felelőssé, azonban ugyanez az arány Délkelet-Ázsiában akár a 15-20\%-ot is elérheti az endémiás előfordulású trópusi pancreatitisnek köszönhetően. ${ }^{8}$ A boncolási adatok alapján a KP prevalenciája magasabb, mint ahogyan azt korábban gondoltuk, így a KP talaján kialakuló DM is gyakoribb kórkép lehet. Ez a feltételezés megmagyarázza, hogy a cukorbetegség miért társul olyan gyakran az exokrin hasnyálmirigy elégtelenségével. ${ }^{9,10}$

Pancreatogen DM-ben mind a béta-, mind az alfa-sejtek károsodnak, ezért a betegség patomecha- nizmusa és klinikai jellemzői is eltérnek az 1-es és 2-es típusú DM-től, s ennek megfelelően a kezelés alapelvei is különbözőek. ${ }^{6}$ A glukagonelválasztás az első és legfontosabb védekező mechanizmus a hypoglykaemia ellen, amelynek megszünése pancreatogen DM-ben súlyos hypoglykaemiához vezethet. Az alkoholfogyasztás és a következményes májkárosodás, az elégtelen táplálékbevitel és az exokrin hasnyálmirigy elégtelenségének köszönhetően csökkent tápanyagfelszívódás csak tovább növeli a hypoglykaemia veszélyét. A pancreatogen DM kezelésével kapcsolatban nincs egységes konszenzus, ${ }^{11}$ mivel az sem az 1-es, sem a 2-es típusú DM terápiás protokolljába nem illik bele. ${ }^{12,13} \mathrm{~A}$ nagy klinikai vizsgálatokban (UKPDS, DCCT) a pancreatogen diabetes kizáró tényezőként szerepelt; következésképpen nincs bizonyítékokon alapuló gyakorlat ebben a betegcsoportban.

Vizsgálatunk célja, hogy az inzulinkezelés hatékonyságát tanulmányozzuk a glykaemiás kontroll, a testsúly és a hypoglykaemia kockázatának vonatkozásában azon betegek esetében, akiknél a DM krónikus pancreatitis szövődményeként alakult ki és cukoranyagcseréjük nem volt megfelelően beállítva. 
1. táblázat. A pancreatogen diabeteses betegek klinikai jellemzői

\begin{tabular}{|c|c|c|c|}
\hline & A csoport & B csoport & C csoport \\
\hline Esetek száma & 16 & 8 & 10 \\
\hline Férfi:nő arány & $14: 2$ & $5: 3$ & $7: 3$ \\
\hline Átlagéletkor (terjedelem) (év) & $54,1(36-76)$ & $60,6(46-76)$ & $58,6(37-76)$ \\
\hline Átlagos testsúly (terjedelem) (kg) & $72,1(60-103,3)$ & $72,7(40,5-94)$ & $77,4(59-104)$ \\
\hline $\begin{array}{l}\text { A krónikus pancreatitis fennállásának átlagos } \\
\text { időtartama (év) }\end{array}$ & $9,4 \pm 6,2$ & $15,9 \pm 6,5$ & $16,9 \pm 8,8$ \\
\hline Pancreasmütét (esetek száma) & $7 / 16$ & $3 / 8$ & $6 / 10$ \\
\hline Meszesedés (esetek száma) & $13 / 16$ & $4 / 8$ & $4 / 10$ \\
\hline Alkoholos eredet & $12 / 16$ & $4 / 8$ & $5 / 10$ \\
\hline A diabetes fennállásának átlagos időtartama (év) & $9,2 \pm 4,0$ & $14,5 \pm 5,4$ & $16,5 \pm 8,3$ \\
\hline Átlagos $\mathrm{HbA}_{1 \mathrm{c}}$-érték (terjedelem) (\%) & $9,7 \pm 1,8$ & $10,0 \pm 1,4$ & $8,8 \pm 1,7$ \\
\hline
\end{tabular}

\section{Betegek és módszerek}

2007. január 1. és 2010. december 31. között olyan pancreatogen DM-es betegeket vontunk be vizsgálatunkba, akiknél a cukorbetegség a már fennálló idült hasnyálmirigy-gyulladás talaján alakult ki, valamint $\mathrm{HbA}_{1 \mathrm{c}}$-értékük elérte vagy meghaladta a 7,0\%-os célértéket.

A kiinduló antidiabetikus kezelést alapul véve a betegeket három csoportba osztottuk. Az A és B csoportban ez orális antidiabeticum (OAD), míg a C csoportban premix inzulin (PMI) volt (1. táblázat). A nem megfelelő glykaemiás kontroll miatt az A csoportban az OAD-terápiát intenzifikált inzulinkezelésre (ICT), míg a B csoportban - együttmüködés hiányában és/vagy gyengénlátás miatt napi kétszeri PMI-re változtattuk. A C csoportban a PMI helyett ICT beállítása történt. Enzimpótlásként betegeink 3-5 × 25000-75000 E pankreatint kaptak.

A $\mathrm{HbA}_{1 c}$, az éhomi vércukor és a testsúly változását, valamint a hypoglykaemia gyakoriságát vizsgáltuk a terápiaváltoztatást követő első két évben.

A KP diagnózisát a morfológiai és funkcionális diagnosztikus kritériumok alapján állítottuk fel. ${ }^{14}$

A DM az Amerikai Diabetes Társaság kritériumrendszere alapján került diagnosztizálásra. ${ }^{5}$ A vizsgált betegek közül cystás fibrosisban senki sem szenvedett.

Minden beteg írásos tájékoztatásban részesült. A vizsgálati protokoll megfelel a Helsinki Deklaráció legutóbbi kiadásában előírtaknak.

Statisztikai becsléseinket páros t-próbával végeztük. A szignifikanciaszintet $\mathrm{p}<0,05$ értéken határoztuk meg. Eredményeinket átlag \pm standard deviáció formájában közöljük.

\section{Eredmények}

A vizsgált négy év során 297 krónikus pancreatitises beteget regisztráltunk, közöttük 112-nek volt pancreatogen DM-e. 30 beteg ( 24 férfi, 6 nő, átlagéletkor 56,4 [36-76] év) $\mathrm{HbA}_{1 c}$-értéke érte el vagy haladta meg a 7,0\%-ot. Az A csoportba 16, a B csoportba 8 , a $\mathrm{C}$ csoportba pedig 10 beteg került bevonásra (1. táblázat). Négy beteget a 2 éves ellenőrzés során észlelt elégtelen glykaemiás kontroll $\left(\mathrm{HbA}_{1 \mathrm{c}}>9 \%\right)$ miatt a $\mathrm{C}$ csoportba soroltunk át. A KP átlagos időtartama a 10 évet meghaladta. A betegek $47 \%$-a korábban hasnyálmirigy-mütéten esett át, 63\%-uknál pancreasmeszesedés alakult ki. A KP kórokaként az esetek 63\%-ában a túlzott alkoholfogyasztás volt felelőssé tehető (1. táblázat).

2. táblázat. Kezdeti orális antidiabetikus terápia pancreatogen diabetesben az A és $B$ csoportban

\begin{tabular}{|c|c|}
\hline Kezelés & N \\
\hline Metformin-monoterápia & 4 \\
\hline Sulfanylurea-monoterápia & 12 \\
\hline Metformin és sulfanylurea együtt & 3 \\
\hline Sulfanylurea és akarbóz együtt & 2 \\
\hline $\begin{array}{c}\text { Metformin, sulfanylurea és akarbóz hármas } \\
\text { kombinációja }\end{array}$ & 2 \\
\hline $\begin{array}{c}\text { Metformin, sulfanylurea, akarbóz és glitazon négyes } \\
\text { kombinációja }\end{array}$ & 1 \\
\hline
\end{tabular}


Az A és B csoportban az inzulinterápiára való váltást megelőzően az antidiabeticumok széles választékát alkalmazták: metformint vagy sulfanylureát monoterápiában; metformint és sulfanylureát együtt; sulfanylureát akarbózzal társítva; metformin, sulfanylurea és akarbóz hármas kombinációját vagy metformint, sulfanylureát, akarbózt és glitazont együttesen (2. táblázat). Átlagosan az OAD-kezelés 55 \pm 68 hónapig tartott az inzulinra való váltás előtt, ezen időszak alatt a betegek átlagos $\mathrm{HbA}_{1 \mathrm{c}}$-értéke 18,1\%-kal romlott, 8,3 $\pm 1,5 \%$ ról 9,8 $\pm 1,7 \%$-ra $(\mathrm{p}<0,05)$ emelkedett.

Az ICT bevezetését követően 12 héttel az A csoportban az éhomi vércukorérték szignifikáns, 29\%os csökkenését sikerült elérni: 13,0 $\pm 3,9 \mathrm{mmol} / \mathrm{l}$-ről 9,2 $\pm 2,1 \mathrm{mmol} / \mathrm{l}-\mathrm{re}(\mathrm{p}<0,002) . \mathrm{A} \mathrm{HbA}_{1 \mathrm{c}}$-szint szintén szignifikáns, $22 \%$-os javulását tapasztaltuk:

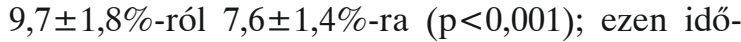
szak alatt 5 beteg érte el a 7,0\% alatti $\mathrm{HbA}_{1 c}$-értéket. A két év során mind az éhomi vércukor, mind a $\mathrm{HbA}_{1 \mathrm{c}}$ további szignifikáns csökkenését tapasztaltuk, míg az előbbi 8,0 22,2 mmol/l-re $(\mathrm{p}<0,001)$, az utóbbi 7,4 $\pm 1,4 \%$-ra $\quad(\mathrm{p}<0,003)$ csökkent. A betegek testsúlya a kétéves utánkövetés során szignifikánsan nem változott $(72,1 \mathrm{~kg}$ vs. $72,9 \mathrm{~kg}, \mathrm{p}=0,708)$. Súlyos hypoglykaemiás epizódot (amely orvosi beavatkozást indokolt volna) csak egy betegnél láttunk, a hypoglykaemia miatti intézeti felvételt a rendszeres, túlzott alkoholfogyasztás eredményezte. Azonban kisebb, alarmírozó tünetekkel járó hypoglykaemiás rosszullétek előfordultak.

A B csoportban a 12 hetes, napi kétszeri PMI-terápia mellett az éhomi glukóz 12\%-kal, 13,2 $\pm 3,1$ mmol/l-ről 11,6 $\pm 2,9 \mathrm{mmol} / \mathrm{l}-\mathrm{re}(\mathrm{p}=0,190)$, míg a $\mathrm{HbA}_{1 \mathrm{c}} 10 \%$-kal, $10,0 \pm 1,4 \%$-ról $9,0 \pm 0,6 \%$-ra $(\mathrm{p}=0,291)$ változott. A két év folyamán a vércukor- és a $\mathrm{HbA}_{1 \mathrm{c}}$-értékek is további javulást (rendre $\mathrm{p}=0,07$ és $\mathrm{p}=0,23)$ mutattak $(10,2 \pm 2,2 \mathrm{mmol} / \mathrm{l}$, ill. $8,6 \pm 0,9 \%$ ), de egyik beteg sem érte el a 7,0\% alatti $\mathrm{HbA}_{1 \mathrm{c}}$-célértéket. A betegek testsúlya szignifikánsan nem változott $(72,7 \mathrm{~kg}$ vs. $71,6 \mathrm{~kg}$, $\mathrm{p}=0,796)$.

A C csoport esetében az ICT bevezetését követően 12 hét alatt az éhomi plazmaglukóz 19\%-kal, $12,2 \pm 3,3 \mathrm{mmol} / \mathrm{l}-\mathrm{ről} \mathrm{9,9} \pm 2,5 \mathrm{mmol} / \mathrm{l}-\mathrm{re}$ változott $(\mathrm{p}=0,127)$, míg a $\mathrm{HbA}_{1 \mathrm{c}} 13 \%$-kal, 8,8 $41,7 \%$-ról $7,7 \pm 1,2 \%$-ra $(\mathrm{p}<0,04)$ csökkent. Két beteg érte el a 7,0\% alatti $\mathrm{HbA}_{1 c}$-értéket. Két év alatt az éhomi vércukor jelentősen nem változott $(9,8 \pm 3,1$ $\mathrm{mmol} / \mathrm{l}, \mathrm{p}=0,139)$, azonban a $\mathrm{HbA}_{1 \mathrm{c}}$ szignifikánsan tovább csökkent $(7,6 \pm 1,2 \%, \mathrm{p}<0,04)(1$ ábra). Jelentős testsúlyváltozás a két év során ezen betegcsoportban sem volt megfigyelhető (77,4 vs. 79,1

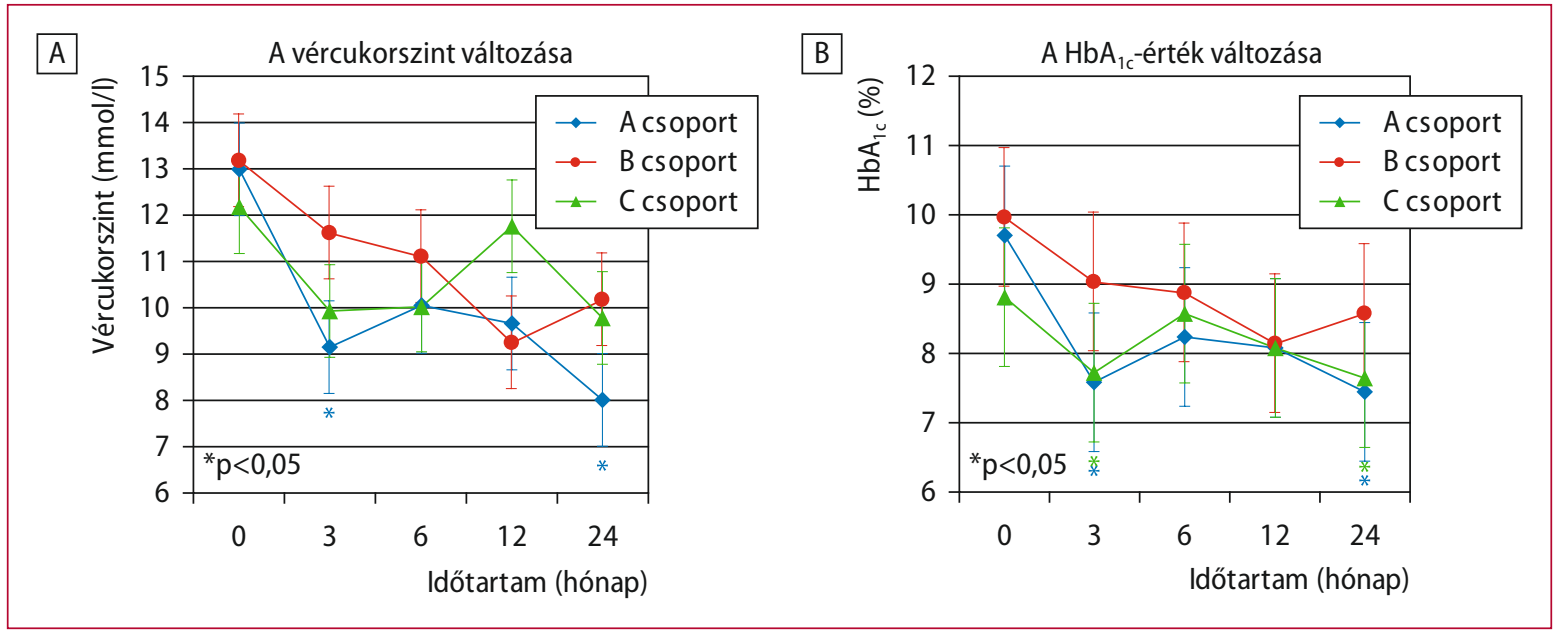

1. ábra. Az inzulinterápia hatékonysága pancreatogen diabetes mellitusban. A vércukorszint ( $A$ ) és a $H b A_{1 c}$-érték (B) változása orális antidiabetikus kezelésről intenzifikált inzulinterápiára (A csoport), illetve napi kétszeri premix inzulin adagolására (B csoport) történő áttérés esetén. A C csoportban a kezdeti premix inzulint intenzifikált inzulinkezelésre változtattuk. 
$\mathrm{kg}, \mathrm{p}=0$,498). Súlyos hypoglykaemiás epizódot, illetve emiatt szükségessé vált kórházi felvételt sem a B, sem a C csoportban nem tapasztaltunk, azonban egy PMI-kezelés alatt álló beteg intézeti ellátásra szorult, mivel cukoranyagcseréjét egy társuló vírusinfekció billentette ki egyensúlyából.

A napi átlagos inzulinszükséglet a terápiamódosítást követően 30,4 $\pm 11,8,29,9 \pm 12,4$ illetve $40,1 \pm 8,1$ NE volt, rendre az A, B és C csoportokban. A C csoport eseteinek elemzése alapján a jobb cukoranyagcsere biztosítása érdekében az ICT során minimálisan nagyobb adag inzulinra volt szükség, mint PMI mellett $(38,4 \pm 12,6$ vs. $40,1 \pm 8,1 \mathrm{NE}, \mathrm{p}=0,91)$.

\section{Megbeszélés}

Vizsgálatunk alapján inzulinterápia alkalmazásával megfelelő hosszú távú cukoranyagcsere-kontroll érhető el pancreatogen DM-ben a hypoglykaemia veszélye nélkül.

A pancreatogen DM terápiájára vonatkozó bizonyítékokon alapuló vizsgálat napjainkig nem történt, mivel a nagy klinikai tanulmányok (UKPDS, DCCT) esetében a pancreatogen DM kizáró kritérium volt. ${ }^{12,13}$

Egyes ajánlások szerint OAD-okkal érdemes kezdeni a terápiát, majd ha ez elégtelenné válik, akkor inzulinra váltani. ${ }^{15}$ Pancreatogen DM-ben azonban az inzulinérzékenyítő készítmények (biguanidok és a glitazonok), illetve a szénhidrát-felszívódást gátló $\alpha$-glukozidáz mellőzése javasolt. Egyrészt, mert a fó patogenetikai probléma az inzulin hiánya, másrészt pedig a fennálló felszívódási zavar és a következményes alultápláltság miatt. Ráadásul a készítmények mellékhatásai (puffadás, hasmenés, hasi fájdalom) az idült hasnyálmirigy-gyulladás hasonló tüneteit csak felerősítik. ${ }^{16}$ Mivel pancreatogen DM-ben az inzulinszekréció kiesése nem teljes, kezdetben a sulfanylurea jó hatású lehet. Tekintettel azonban arra, hogy a KP progresszív betegség, a sulfanylurea a béta-sejtek kimerülését felgyorsítja. ${ }^{17}$ Ezt bizonyítja az az észrevétel is, hogy a sulfanylureakezelésben részesülő betegeink cukoranyagcseréje sokkal korábban elégtelenné vált, mint ahogy a 2-es típusú diabetesesek esetében a másodlagos sulfanylurearezisztencia kifejlődik. ${ }^{18}$ A sulfanylurea ráadásul hy- poglykaemizál és gyakran kontraindikált a kísérő májelégtelenség miatt. ${ }^{3}$ Összességében elmondható, hogy az orális antidiabetikus kezelés pancreatogen DM-ben nem javallt.

Pancreatogen DM-ben az elsődleges hormonális eltérés a csökkent inzulinszekréció. ${ }^{1,2,3}$ Azonban a cukorbetegség kialakulása nemcsak a károsodott inzulintermelésnek köszönhető, hanem a társuló inzulinrezisztenciának és az inzulin megváltozott hatásának. ${ }^{19,20} \mathrm{~A}$ hasnyálmirigy által kiválasztott ellenregulációs hormonok (a szomatosztatin és a glukagon) csökkent termelődése miatt is nehezített pancreatogen DM-ben a megfelelő glykaemiás kontroll biztosítása. Az exokrin hasnyálmirigy elégtelensége miatt károsodott szénhidrát-felszívódás, a rendszeres alkoholfogyasztás és a társuló májbetegség, a diéta be nem tartása, a gyógyszerek önkényes elhagyása és a gyorsult béltranzit mind csak tovább nehezíti a cukoranyagcsere megfelelő beállítását. ${ }^{3}$ Ezen tényezők gyakori, súlyos és előre nem jelezhető hypoglykaemiás epizódokat idézhetnek elő, olyanokat, amelyek akár halállal is végződhetnek. ${ }^{6,21}$ A korábbi megfigyelésekkel ellentétben ${ }^{6}$ vizsgálataink arra utalnak, hogy az inzulinnal kezelt pancreatogen diabeteses betegek körében a súlyos hypoglykaemia nem olyan gyakori probléma. A hypoglykaemia a terápiától függetlenül sokkal gyakrabban fordult elő azoknál a betegeknél, akik továbbra is rendszeresen fogyasztottak alkoholt, mint azoknál, akik fel tudtak hagyni ezen káros szenvedélyükkel. ${ }^{6}$ Éppen ezért, az ICT csak azon betegeknek ajánlható, akik nem fogyasztanak alkoholt és képesek kezelőorvosukkal együttműködni. A megfelelő enzimszubsztitúció elengedhetetlen a pancreatogen diabetest kísérő felborult metabolikus egyensúly mérséklése érdekében. ${ }^{22}$ Enzimpótlás nélkül a tápanyagok felszívódása kiszámíthatatlanná válik, és az inzulin vércukorcsökkentő hatása korábban jelentkezik a tápanyagok vércukoremelő hatásánál, ami hypoglykaemiához vezet. ${ }^{23}$ Főétkezések mellé adott 25000-50000 NE lipázt tartalmazó gyomornedv-ellenálló kapszula bevétele, valamint a kisebb étkezések során elfogyasztott 10000-25000 NE lipáz a legtöbb beteg számára elégséges enzimpótlást jelent. ${ }^{24}$

A pancreatogen diabetes megfelelő kezeléséhez elengedhetetlen a kísérő hasnyálmirigy-betegség diagnosztizálása. Korábbi tanulmányok alapján a 
pancreatogen DM-et a diabetesek 1-7\%-áért tették felelőssé. ${ }^{6,10}$ Azonban az exokrin és endokrin hasnyálmirigy betegségeinek gyakori (40\%) társulása a pancreatogen DM magasabb prevalenciáját sejteti. ${ }^{10}$ Hardt és munkatársai a pancreatogen diabetes kritériumait (azaz az autoantitestek hiányát, a társuló exokrin pancreaselégtelenséget és a típusos morfológiai eltéréseket) is figyelembe véve diabeteses betegeiket újracsoportosították, ez alapján a páciensek 8\%-a a DM 3c csoportjába került. Ez az arány is alábecsültnek tűnik, mert definíciójuk szerint mind az exokrin hasnyálmirigy elégtelenségének, mind a morfológiai eltéréseknek jelen kellett lenniük a KP diagnosztizálásához, azonban a funkcionális tesztek csupán a diabeteses betegek 15\%-ánál voltak elérhetők. ${ }^{9}$ A pancreatogen DM pontos előfordulása protokollfüggő, és sok múlik a diabetológusok és a gasztroenterológusok közötti kommunikáción is. Minden újonnan felfedezett diabeteses beteg esetén, illetve akkor, ha az optimálisnak vélt antidiabetikus kezelés ellenére a cukoranyagcsere nem kielégítő, szükséges a képalkotó vizsgálatok elvégzése a pancreatogen DM diagnosztizálásához. ${ }^{25}$ A pancreascarcinomás esetek 30\%-ában újonnan diagnosztizált pancreatogen DM mutatható ki, ami szintén a pancreas morfológiai vizsgálatának szükségességét támasztja alá frissen felfedezett DM esetén. ${ }^{26}$

Pancreatogen DM-ben mind a bazális, mind a postprandialis inzulinelválasztás károsodott. A fiziológiás inzulinszekréció biztosítása érdekében mind az étkezésekkor szükséges, mind a bazális inzulinszekréciót pótolni kell. ${ }^{27}$ A napi többszöri inzulinadagolás pozitív hatását pancreatogen diabetesben már leírták. ${ }^{28} \mathrm{Az}$ inzulinterápia bevezetése a béta-sejtek kimerülését megelőzően javasolt. ${ }^{29}$ Az inzulinadagolás mihamarabbi, időben történő megkezdésével a betegek saját hormonelválasztását óvjuk. A még megmaradó endogén inzulinszekréció alkalmazkodni képes a vércukor ingadozásához, ezáltal a betegek kevésbé hajlamosak a hypoglykaemiára és cukoranyagcseréjük is stabilabb.

Hosszú hatású inzulin napi kétszeri adagolása pancreatogen diabetesben az elhúzódó hatások akkumulálódása, ezáltal a súlyos hypoglykaemia veszélye miatt általában nem javasolt. ${ }^{30} \mathrm{Az}$ OAD-terápiát követően PMI-kezeléssel a $\mathrm{B}$ csoport betegeinek egy részében tudtuk csak a $\mathrm{HbA}_{1 \mathrm{c}}$ értékét csökkenteni; a betegek felében az elégtelen glykaemiás kontroll miatt PMI helyett ICT alkalmazására kényszerültük. A C csoportban pedig a megfelelő glykaemiás kontroll biztosítása érdekében a napi kétszeri PMI helyett intenzifikált inzulinkezelésre kellett áttérni. Ez a terápia megóvja az endogén inzulintermelést, ráadásul ez a fajta adagolási mód együttműködő beteg esetén a napi tevékenységhez biztonsággal igazítható.

Vizsgálatunk alapján összességében elmondható, hogy az OAD-kezelés pancreatogen DM-ben korán elégtelenné válhat. Hosszú távon a legmegfelelőbb cukoranyagcsere-kontroll intenzifikált konzervatív inzulinterápia mellett érhető el, anélkül, hogy súlyosabb hypoglykaemiától tartani kellene. Az emésztés és a felszívódás javítása érdekében, valamint a hypoglykaemia veszélyének csökkentése céljából a hiányzó pancreasenzimeket nagy dózisban pótolni kell.

\section{Köszönetnyilvánítás}

Köszönetet mondunk a TÁMOP-4.2.1./B-09/1/ KONV. pályázatnak munkánk támogatásáért. 


\section{rodalom}

1. Owyang, C: Endocrine changes in pancreatic insufficiency (In: Go VLW, DiMango EP, eds: The Pancreas: Biology, Pathology and Diseases) New York, Raven Press, 1993; 803-813.

2. Angelopoulos, N, Dervenis, C, Goula, A, Rombopoulos, G, Livadas, S, Kaltsas, D, et al: Endocrine pancreatic insufficiency in chronic pancreatitis. Pancreatology 5: 122-131, 2005.

3. Czakó L, Hegyi P, Rakonczay Z, Wittmann T, Otsuki, M: Interactions between the endocrine and exocrine pancreas and its clinical relevance. Pancreatology 9:351-359, 2009.

4. Czakó L: Exokrin pancreas betegségek és diabetes mellitus. Lege Artis Med 18: 745-750, 2008.

5. American Diabetes Association: Diagnosis and classification of diabetes mellitus. Diabetes Care 30: $542-547,2007$.

6. Ito, T, Otsuki, M, Igarashi, H, Kihara, Y, Kawabe, K, Nakamura, T, et al: Epidemiological study of pancreatic diabetes in Japan in 2005. A Nationwide Study. Pancreas 39: 829$835,2010$.

7. Malka, D, Hammel, P, Sauvanet, A, Rufat,, , O'Toole, D, Bardet, $P$, et al:: Risk factors of diabetes mellitus in chronic pancreatitis. Gastroenterology 119: 1324-1332, 2000.

8. Mohan, V, Barman, KK, Rajan, VS, Chari, ST, Deepa, R: Natural history of endocrine failure in tropical chronic pancreatitis: a longitudinal follow-up study. I Gastroenterol Hepatol 20: 1927-1934, 2005.

9. Hardt, PD, Brendel, MD, Kloer, HU, Bretzel, RG: Is pancreatic diabetes (type 3c diabetes) underdiagnosed and misdiagnosed? Diabetes Care 2: 165-169, 2008.

10. Hardt, PD, Hauenschild, A, Nalop, J, Marzeion, AM, Jaeger, C, Teichmann, J, et al:: High prevalence of exocrine pancreatic insufficiency in diabetes mellitus. A multicenter study screening fecal elastase-1 concentrations in 1,021 diabetic patients. Pancreatology 3: $395-402,2003$.

11. Price, S, Cole, D, Alcolado, JC: Diabetes due to exocrine pancreatic disease - a review of patients attending a hospital-based diabetes clinic. QJ Med 103: 759-763, 2010.

12. Nathan, DM, Buse, JB, Davidson, MB Ferrannini, E, Holman, RR, Sherwin, R, et al.: Medical management of hyperglycaemia in type 2 diabetes mellitus: a consensus algorithm for the initiation and adjustment of therapy: a consensus statement from the American Diabetes Association and the European Association for the Study of Diabetes. Diabetologia 52: 17-30, 2009.

13. European Diabetes Policy Group 1998: A desktop guide to Type 1 (insulin-dependent) diabetes mellitus. Diab Med 16:253-266, 1999.

14. DiMagno, MJ, DiMagno, EP: Chronic pancreatitis. Curr Opin Gastroenterol 26: 490-498, 2010.

15. Choudhuri, G, Lakshmi, CP, Goel A: Pancreatic diabetes. Trop Gastroenterol 30: 71-75, 2009.

16. Diem P: Pathogenesis and treatment of diabetes secondary to chronic pancreatitis. (In: Büchler MW, Malfertheiner P [eds]: Chronic pancreatitis.) Berlin, Blackwell Science; 2002: 355-358.

17. Gerö L: A pancreatogen diabetes okai, tünettana és kezelése. Diabetologia Hungarica 10: 19-22, 2002.

18. Satoh, J, Takahashi, K, Takizawa, Y, Ishihara, H, Hirai, M, Katagiri, H, et al.: Secondary sulfanylurea failure: comparison of period until insulin treatment between diabetic patients treated with gliclazide and glibenclamide. Diabetes Res Clin Pract 70:291-297, 2005.

19. Andersen, DK: Mechanisms and emerging treatments of the metabolic complications of chronic pancreatitis. Pancreas 35: 1-15, 2007.

20. Cavallini, G, Vaona, B, Bovo, P, Cigolini, M, Rigo, L, Rossi, F: Diabetes in chronic alcoholic pancreatitis. Role of residual beta cell function and insulin resistance. Dig Dis Sci 38: 497 $501,1993$.

21. Sjoberg, RJ, Kidd, GS: Pancreatic diabetes mellitus. Diabetes Care $12: 715-724,1989$.

22. Ewald, N, Bretzel, RG, Fantus, IG, Hollenhorst, M, Kloer, HU, Hardt, PD, et al:. Pancreatin therapy in patients with insulin-treated diabetes mellitus and exocrine pancreatic insufficiency according to low fecal elastase 1 concentrations. Results of a prospective multi-centre trial. Diabetes Metab Res Rev 23: 386-391, 2007.

23. Czakó L, Takács T, Hegyi P, Prónai L, Tulassay Zs, Lakner L, et al: Quality of life assessmen after pancreatic enzyme replacement therapy in chronic pancreatitis. Can $J$ Gastroenterol 17: $597-603,2003$.
24. Domínguez-Muñoz, JE: Pancreatic enzyme therapy for pancreatic exocrine insufficiency. Curr Gastroenterol Rep 9: 116-122, 2007.

25. Dominguez-Muñoz, JE, Cigarran-Vicente, B, Alvarez-Castro, A, Iglesias-Garcia, J: Poor glycemic control in type 2 diabetes is associated to abnormalities in the exocrine pancreas: a pilot case-control study. Pancreatology 11: 199-227, 2011.

26. Magruder, JT, Elahi, D, Andersen, DK: Diabetes and pancreatic cancer: chicken or egg? Pancreas 40: 339-351, 2011.

27. Iván G: The principles of treatment of pancreatic diabetes. Orv Hetil 150: 273-276, 2009.

28. Miura, J, Yokoyama, J, Miura, A Mori, Y, Ito, K, Ikeda, Y: Clinical efficacy of multiple insulin injection regimen in pancreatogenic diabetes (in Japanese). J Jpn Diabet Soc 34: 685691, 1991.

29. Kawabe, K, Ito, T, Igarashi, H, Takayanagi, R: The current managements of pancreatic diabetes in Japan. Clin J Gastroenterol 2: 1-8, 2009.

30. Starke, AAR, Cupers, HJ, Berger, M: Therapeutic problems in diabetes secondary to pancreopathy. (In: Tiengo, A, Alberti, KGMM, Del Prato, S, Vranic, M (eds): Diabetes secondary to pancreopathy.) Amsterdam, Excepta Medica, 1988; 227-233.
Közlésre érkezett: 2011. szeptember 23.

Közlésre elfogadva: 2012. május 2.

\section{A szerzö levelezési címe:}

\section{Dr. Czakó László}

Szegedi Tudományegyetem, I. Belgyógyászati

Klinika

6720 Szeged, Korányi fasor 8-10.

E-mail: czako.laszlo@med.u-szeged.hu 